هدى إعمال قواعد القانون البحري

الدولي والمقارن في هشروع القانون

العربي الاسترشادي البحري 2016

در اسة تحليلية مقارنة

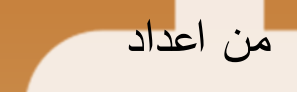

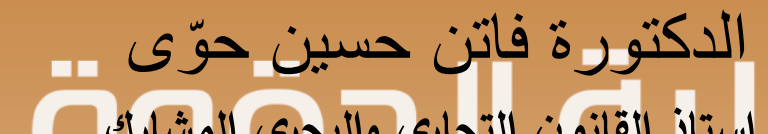

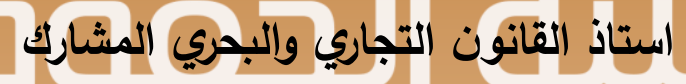

بكلية الحقوق والعلوم السياسية بجامعة بيروت العربية

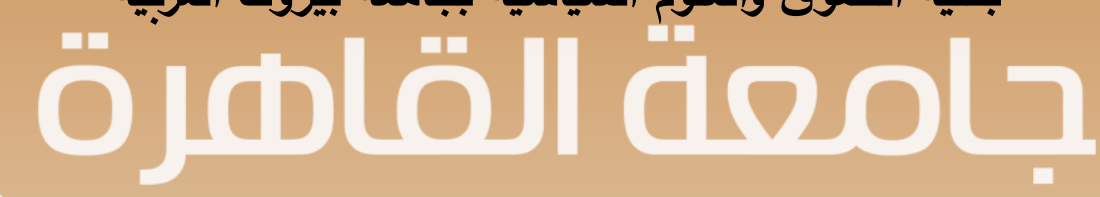




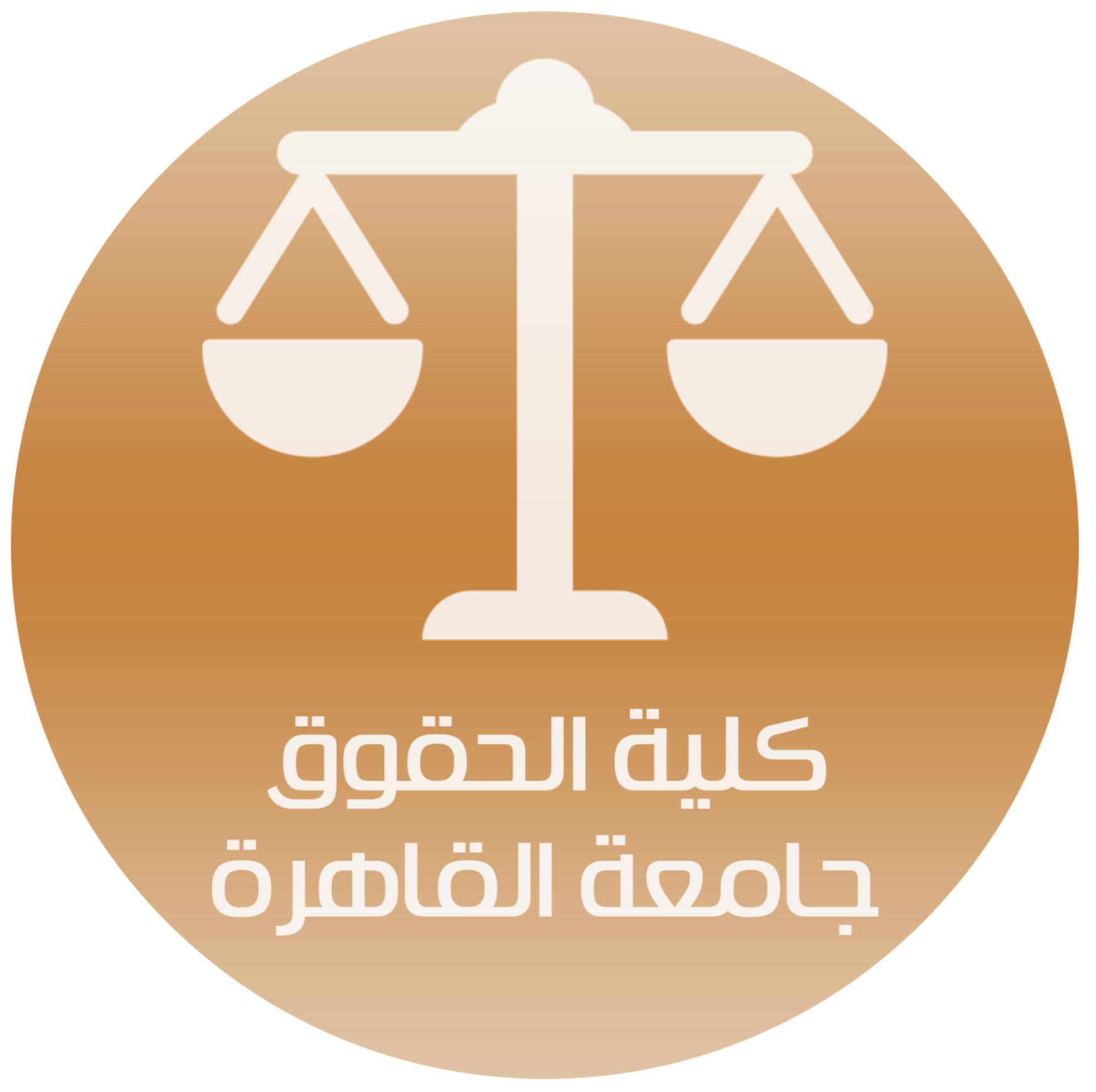


يعتبر مشـروع القـانون العربي الاسترشـادي البحري- محل البحث - خطوة

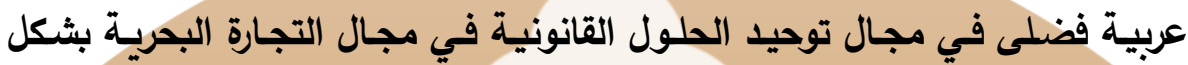

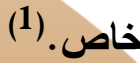

فلا يوجد - بحسب لجنة الامم المتحدة للقانون التجاري الدولي اليونسترال - قال

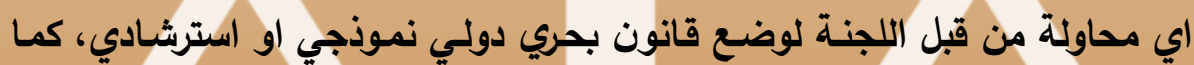

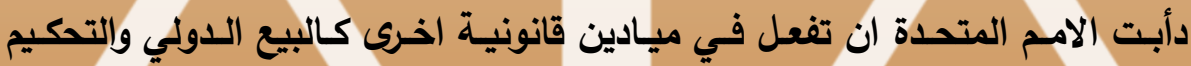

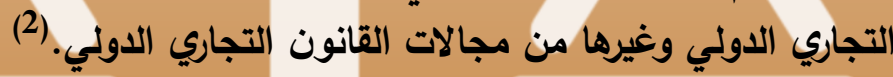

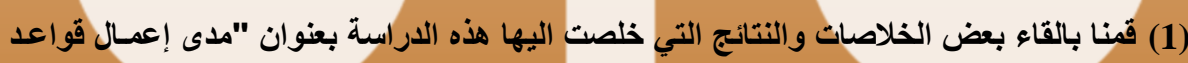

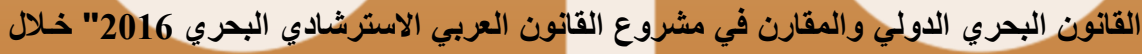

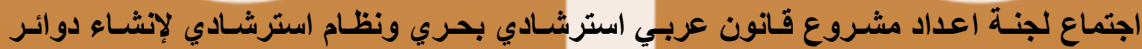

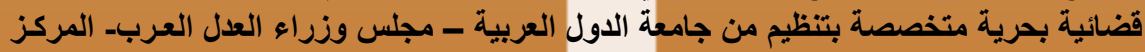

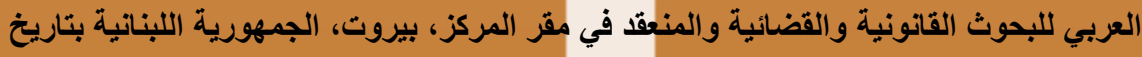

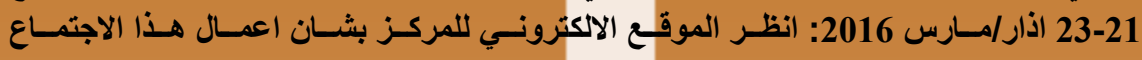
www.carij.org

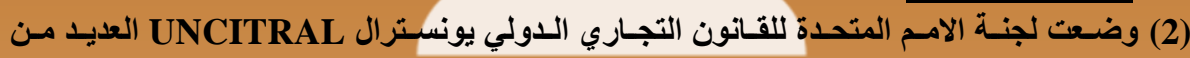

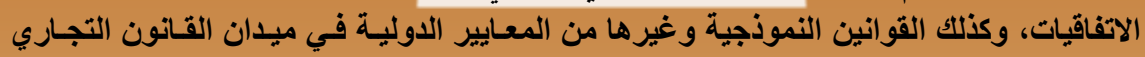

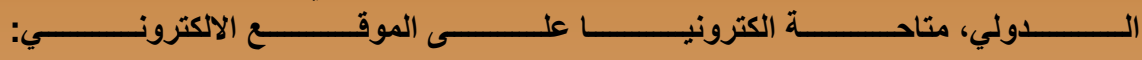

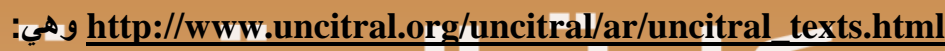
• في مجال التحكيم والتوفيق التجاريين الدوليين: (1) الاتفاقيات: - اتفاقية الأمم المتحدة بثـأن

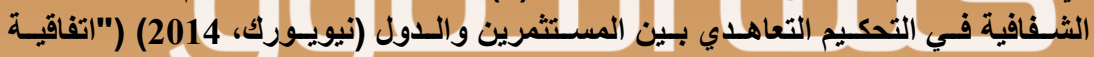

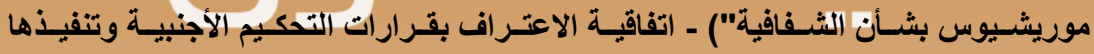

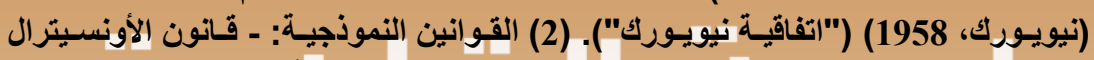

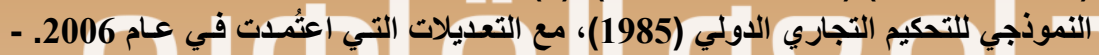

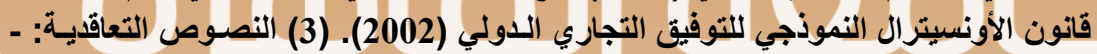

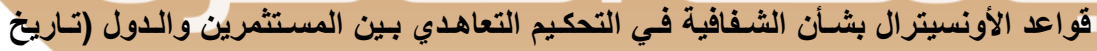

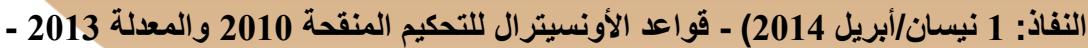

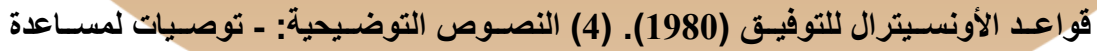

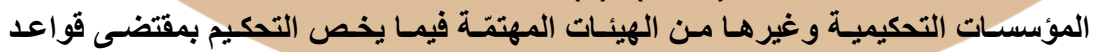

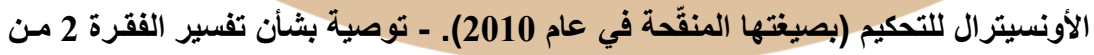

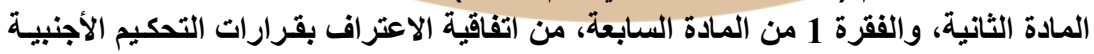

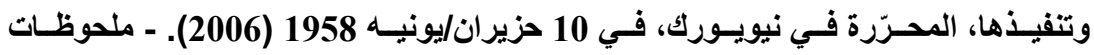


الأونسيترال عن تنظيم إجراءات التحكيم (1996). - توصيات لمساعدة المؤسسات التحكيميـة

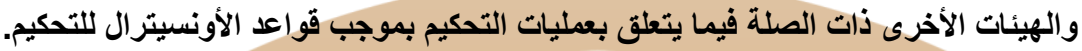

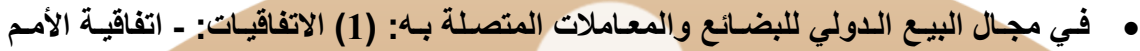

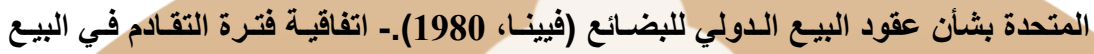

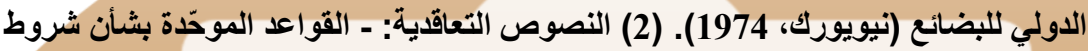

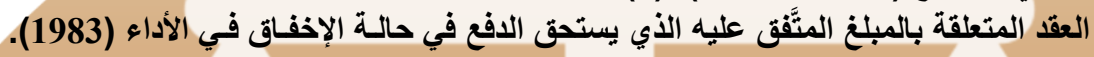

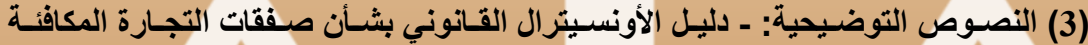

• في مجال المصالح الضمانية: (1) الاتفاقيات: - اتفاقية الأمم المتحدة بشأن إحالة المستحقات

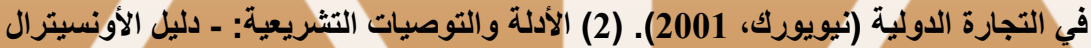

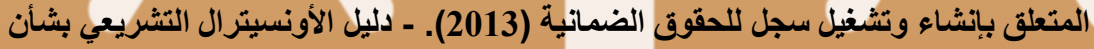

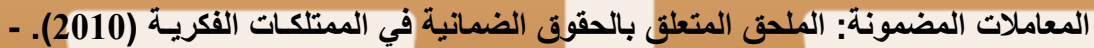

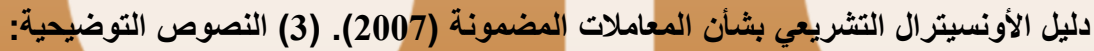

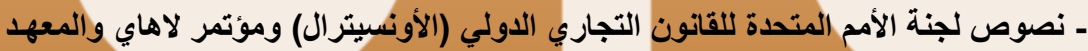

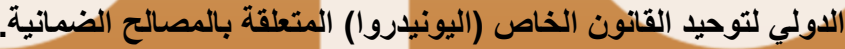

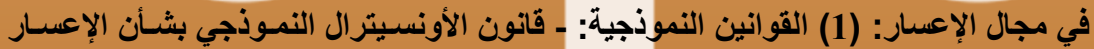

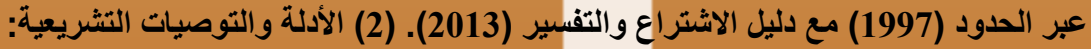

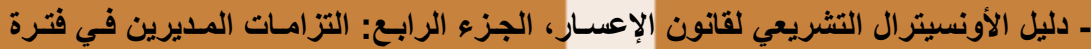

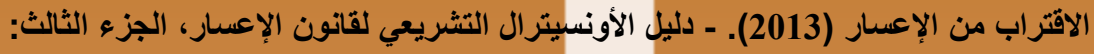

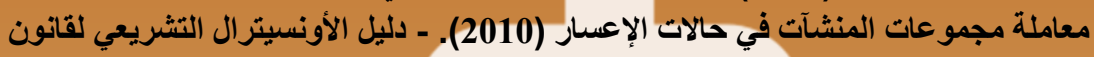

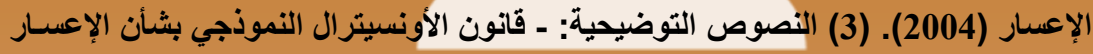

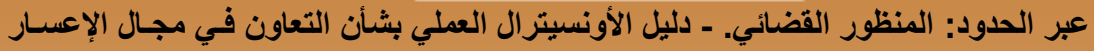
عبر الحدود (2009).

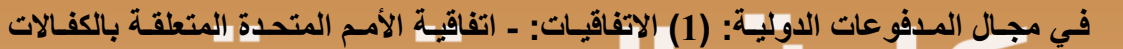

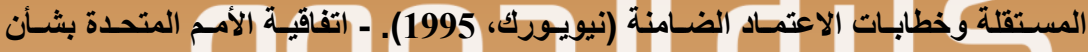
السفاتج (الكمبيالات) الاوليـة والسنـات الات الإذنيـة الدوليـة (نيويـورك، 1988).

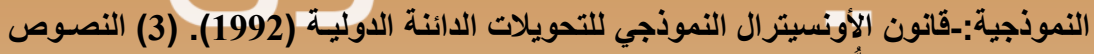

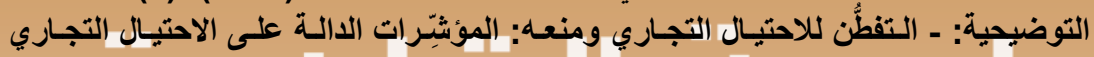

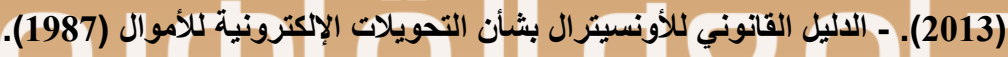

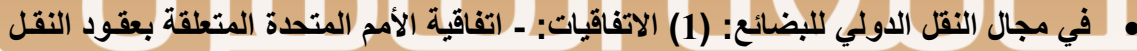

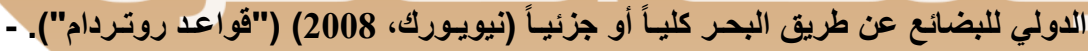

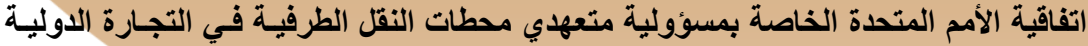

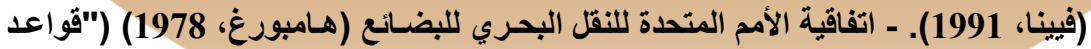

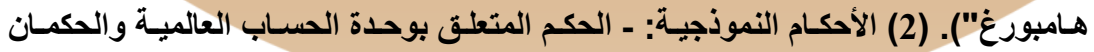

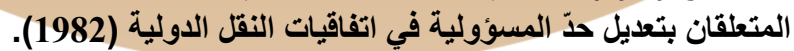

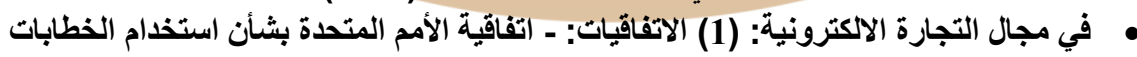

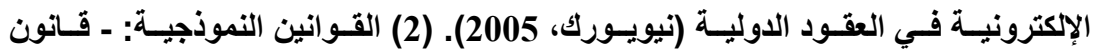




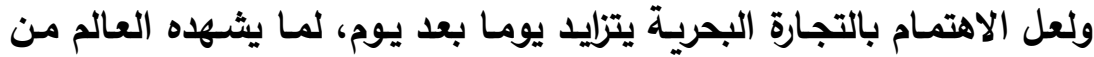

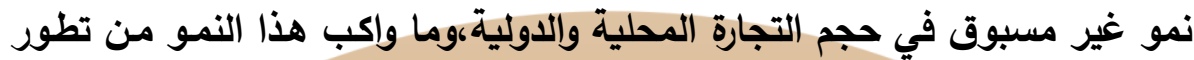

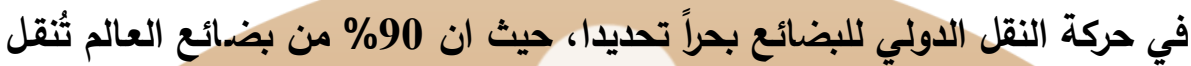

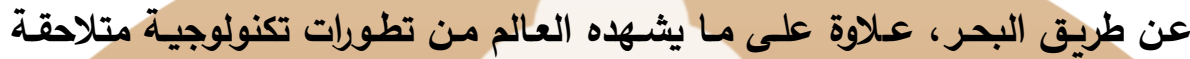

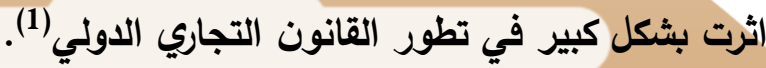

لذلك فمن الاهمية بمكان الاشـادة بجهود جامعة الدول العربية وضـع قانون

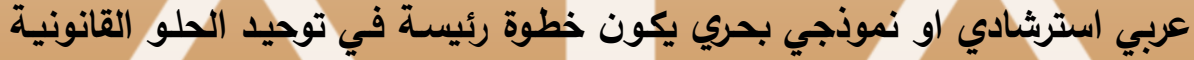

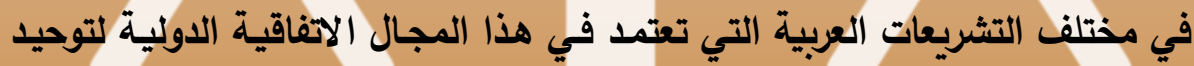
بعض القواعد المتعلقة بسندات الشحن الموقعة في بروكسل سنة 1924 وتعديلاتها

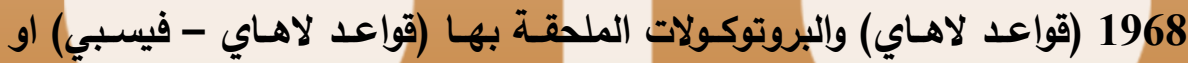

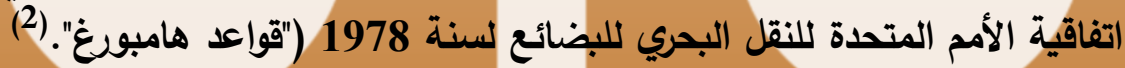

الأونسيترال النموذجي بشأن التوقيعات الإكترونية (2001). - قانون الأونسيترال النموذجي

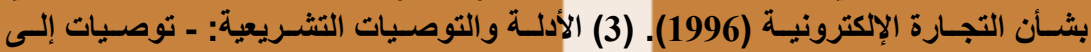

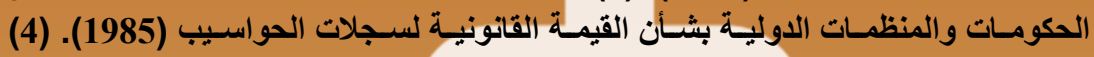

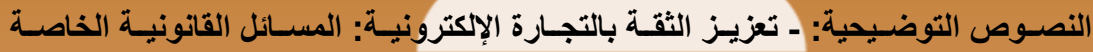

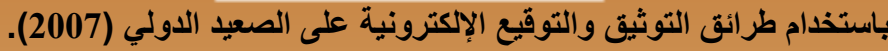

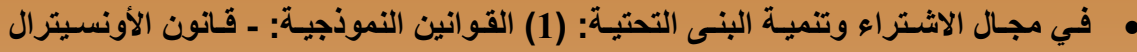

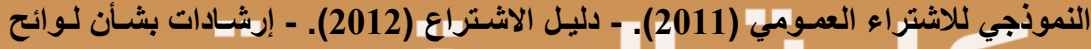

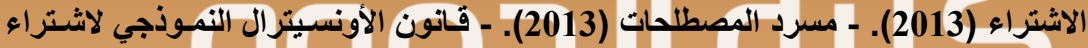

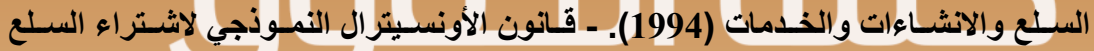

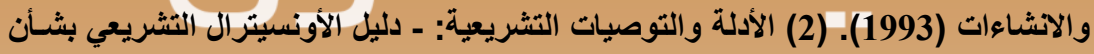

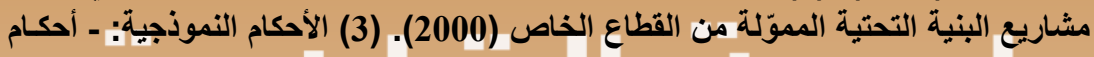

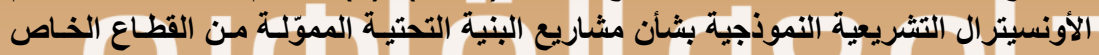

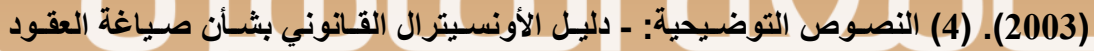
الأدلية لتثييا المنشآت الصناعية (1987) (1987).

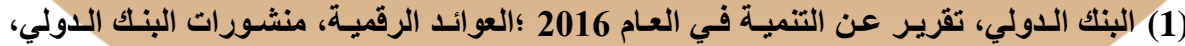

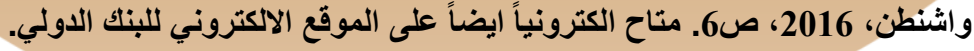
(2) انظر تفصيلا في مقارنة المعايير الدولية في مجال النقل البحري الدألئي:

BERLINGIERI, Francesco, A comparative analysis of the Hague-Visby Rules, the Hamburg Rules and the Rotterdam Rules, paper delivered at the General Assembly of the International Association of Average Adjusters- 
وتُعتبر هذه الاتفاقية محاولـة من الامـم المتحدة نحو تحقيق التوازن بين

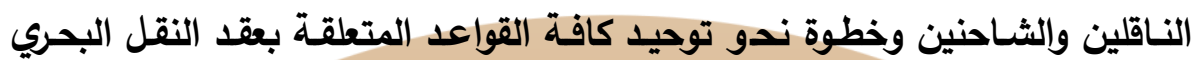

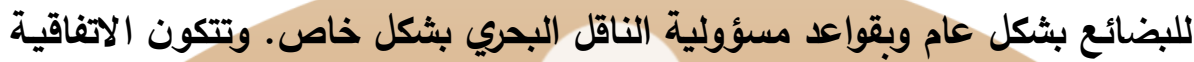

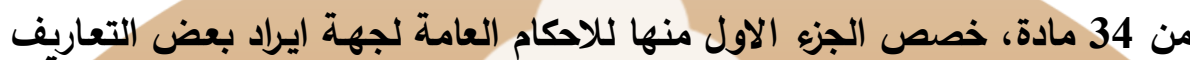

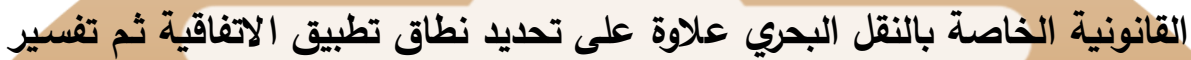

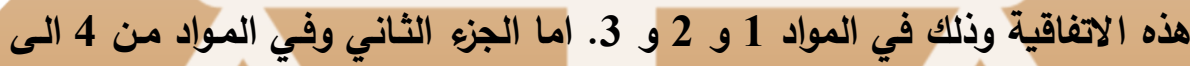

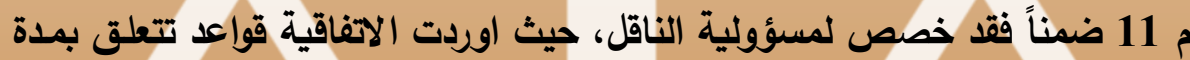

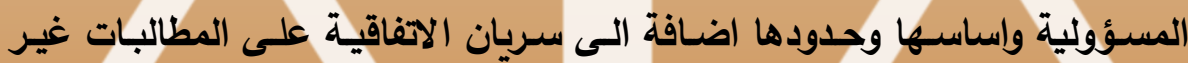

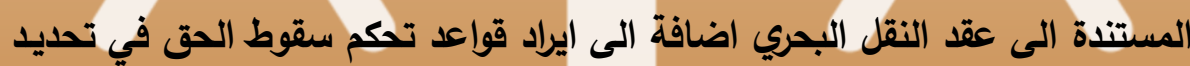

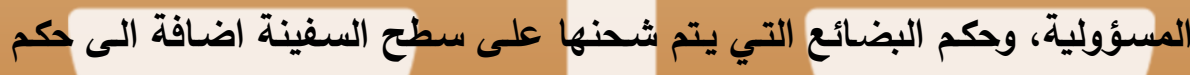

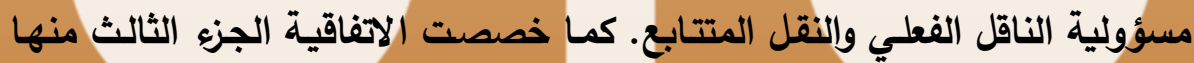

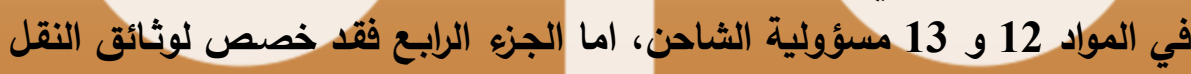

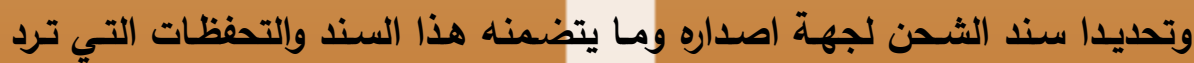

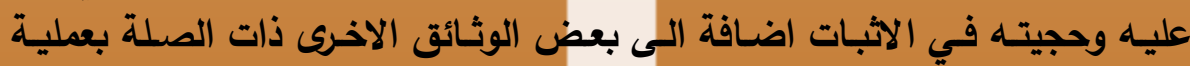

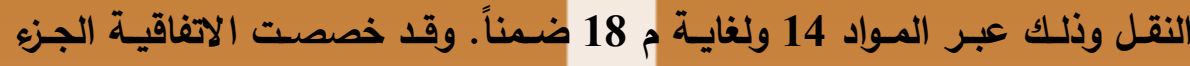

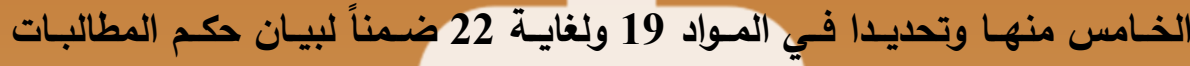

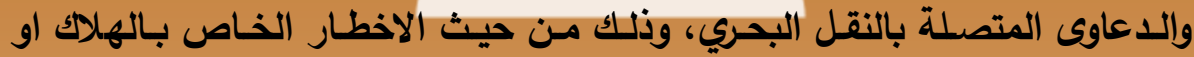

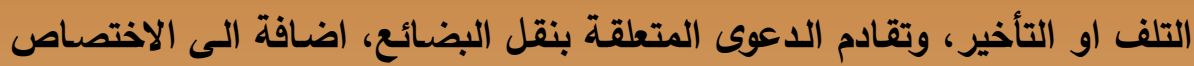

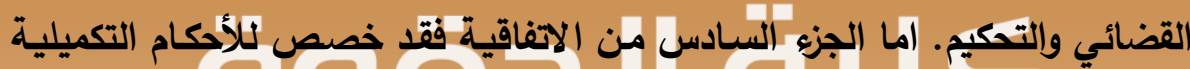
ذات الصلة بالنقل البحري وذلك في المواد 23 ولغاية 26 ضمناً، وفي الجزء الساقية السابع

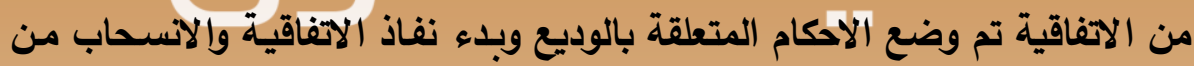

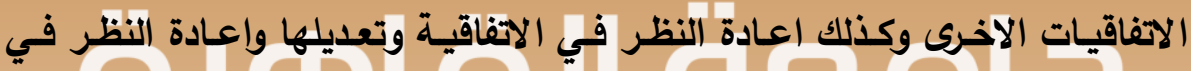

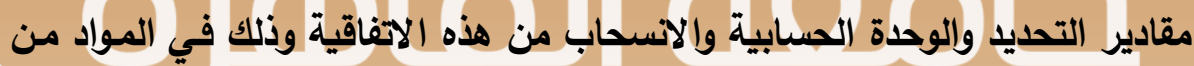

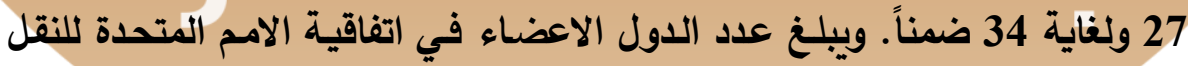

AMD,Marrakesh, 5-6 November 2009, available online at www.comitemaritime.org/draft/pdf/Comparative analysis.pdf and http://www.uncitral.org/pdf/english/workinggroups/wg_3/Berlingieri_paper comparing_RR_Hamb_HVR.pdf 
العربي الاسترشادي البحري 2016

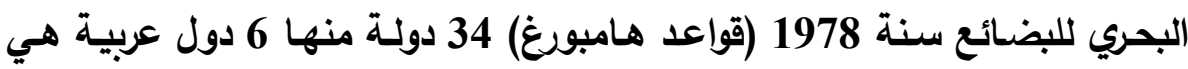

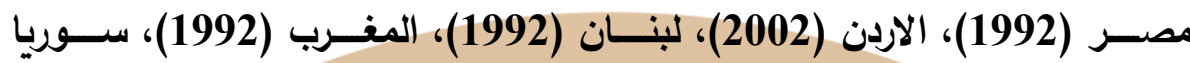

(1992). (2003)، وتونس (1992)

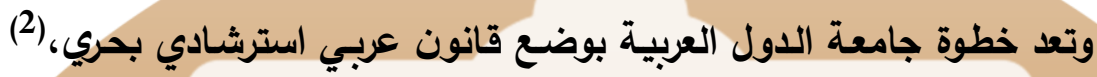

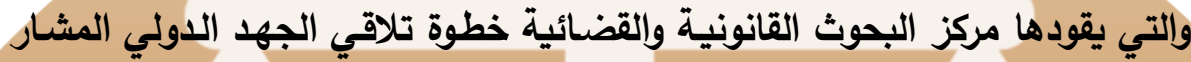
اليه بقواعد هامبورغ وكذلك الجها الدولي الذي اعتمد سنة 2008 اتفاقية الأمـ التما

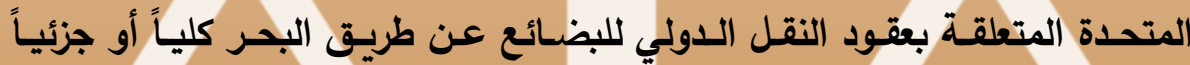

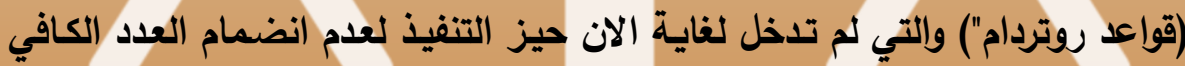

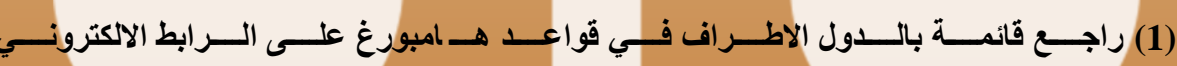
http://www.uncitral.org/uncitral/ar/uncitral texts/transport_goods/Ham

burg status.html

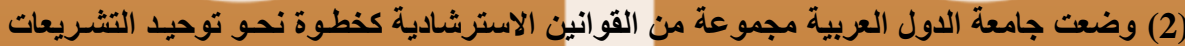

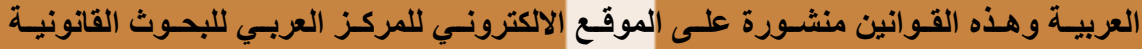

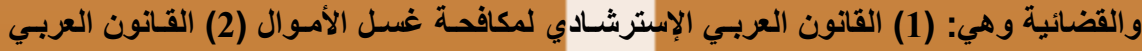

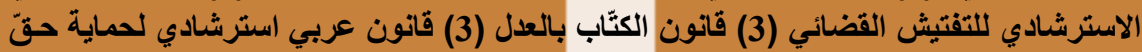

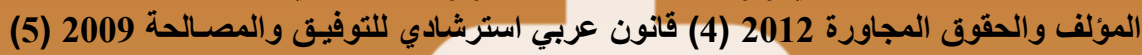

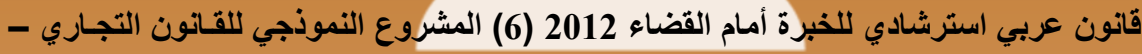

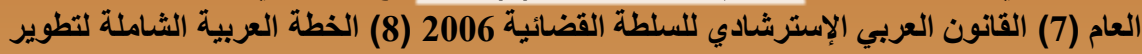

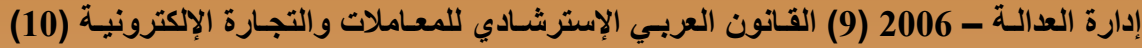

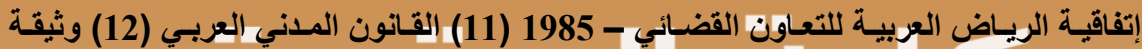

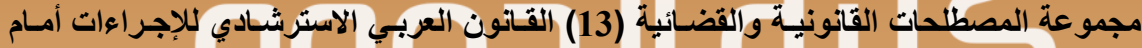

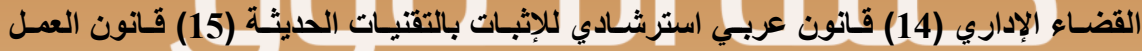

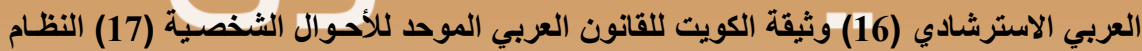

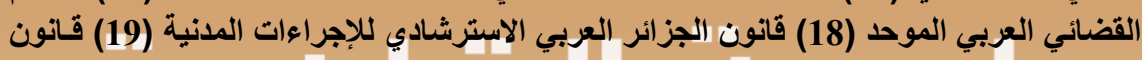

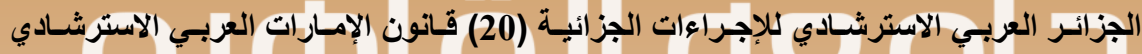

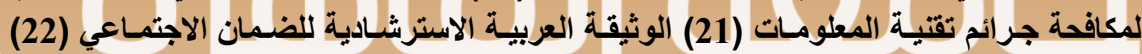

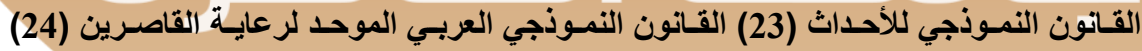

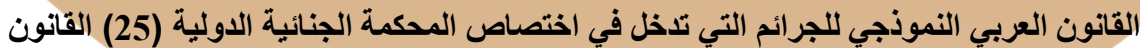

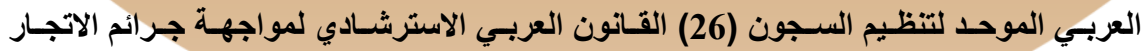

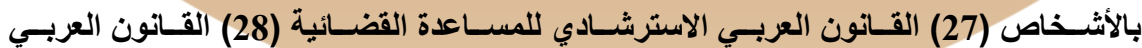

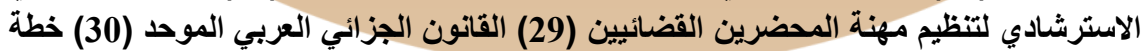

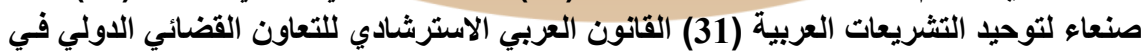
المسائل الجنائية (32) القانون العربي الموجد للتسجيل العقاري العيدي 
من الدول كدول اطراف لغاية الان، وهذ القواعد اتت كي توفر إطارا قانونيا موحدا

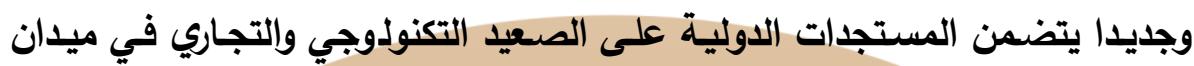

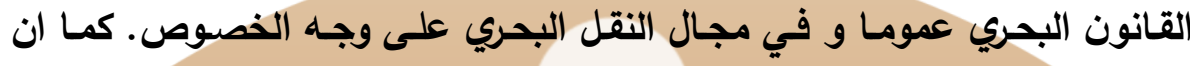

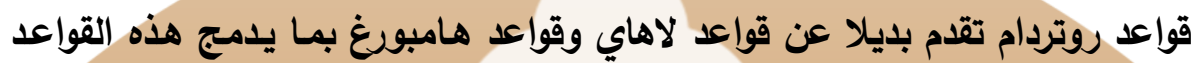

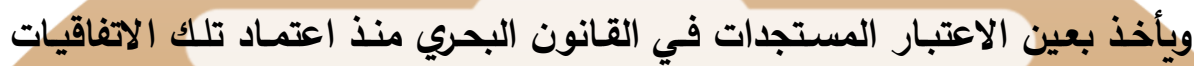

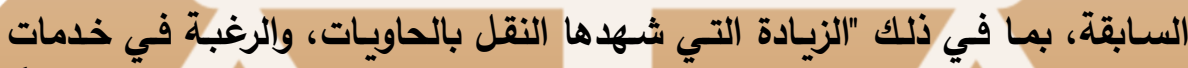

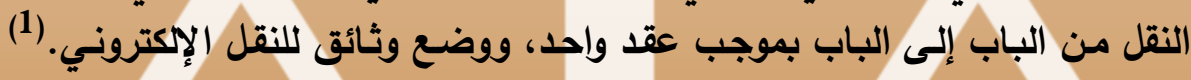

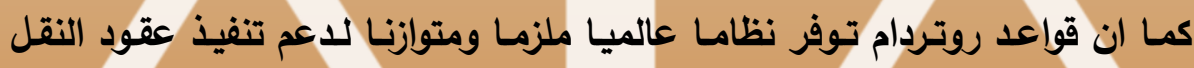

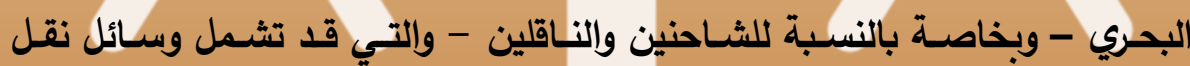

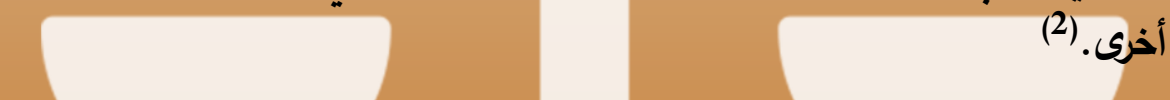

وقد عبرت الامم المتحدة حينذاك عن ان الهدف الرئيس من هذه الاتفاقية

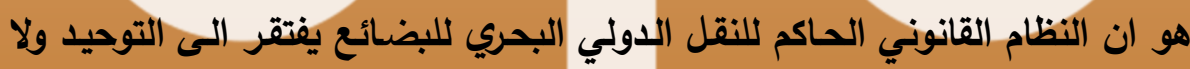

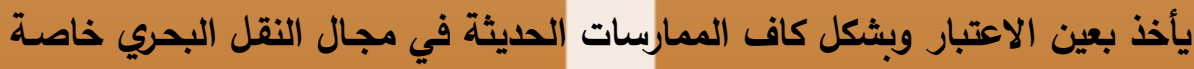

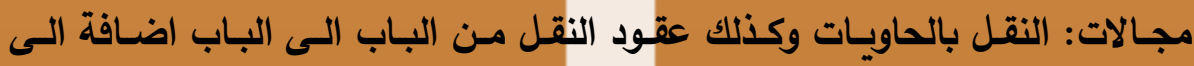

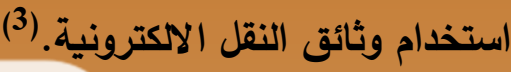

(1) Paul Page, ROTTERDAM Rules, Rotterdam Rules, Editor's Letter "Rotterdam Rules", Journal of Commerce, 6 July 2009, Publisher; Liam Power, 2009

http://www.uncitral.org/pdf/english/texts/transport/rotterdam_rules/JO C_editorial_6July09.pdf

(2) Dr. HONKA, Hannu, United Nations Convention on Contracts for the International Carriage of Goods Wholly or Partly by Sea - Scope of application and Freedom of contract, P.2, CMI Colloquium on the Rotterdam Rules, Rotterdam, September 21, 2009, Published on http://www.rotterdamrules2009.com/cms/uploads/Def.\%20tekst\%20Ha nnu\%20Honka.pdf

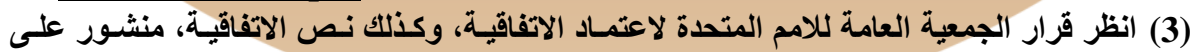

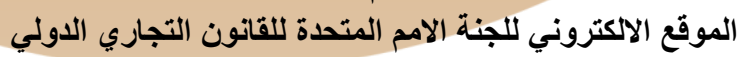

http://www.uncitral.org/pdf/arabic/texts/transport/Rotterdam_Rules/Rotter dam-Rules-A.pdf 


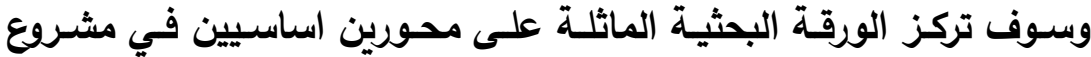

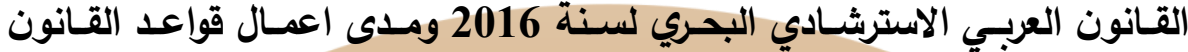
البحري الدولي ضمنه، والمحورين هما:النقل البحري والتامين البحري.

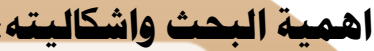

تنبع اهمية البحث في مدى إعمال قواعد القانون البحري الدولي في مشروع الإنياء

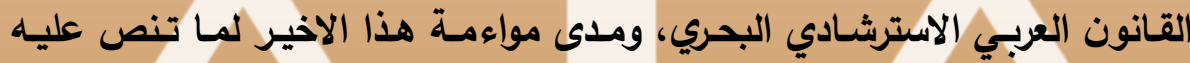

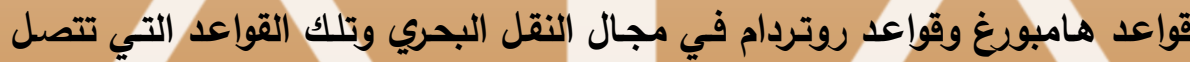

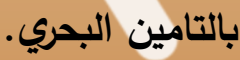

بينما تتركز الاشكالية في تبيان مدى توافق مشروع القانون العربي المشار

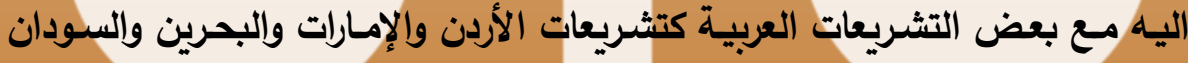

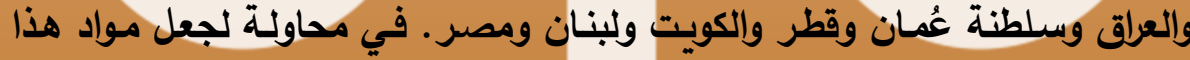

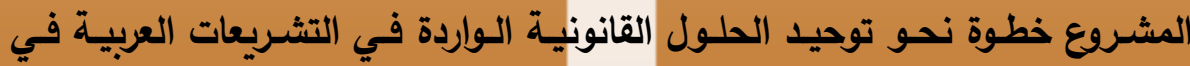
مجالي النقل والتأمين البحريين.

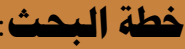
سوف نعرض لمشروع القانون العببي الاسترشادي البحري ومدى مواءمتـه

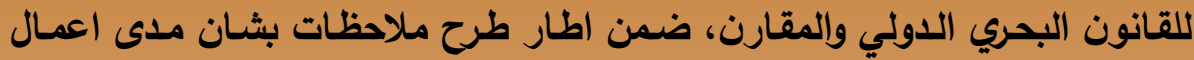

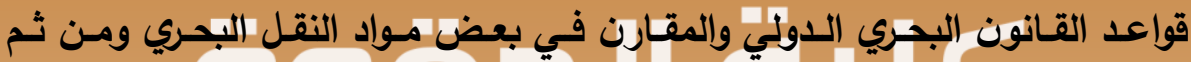

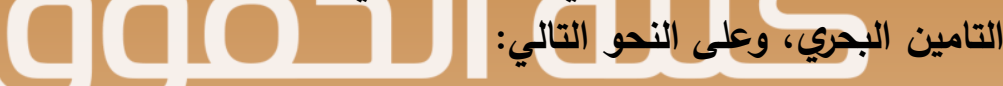
المبحث الاول: ملاحظات بشأن مدى إعمال قواعد القانون البحري الدولي

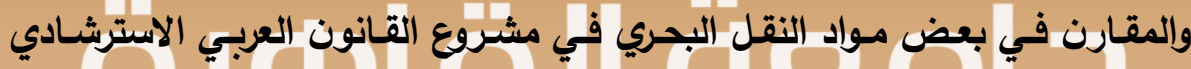

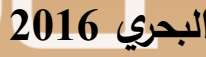

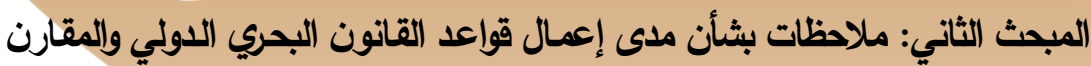
في بعض مواد التأمين البحري في مشروع القانون العببي الاسترشادي البحري 2016 


\section{الابمث الاول}

ملاحظات بشأن مدى إعمال قواعد القانون البمري الدولي والاتقارن في البول

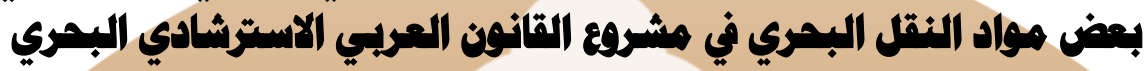
2016

عرض مشـروع القـانون البحري العربـي الاسترشــادي البحري للنقل البحري

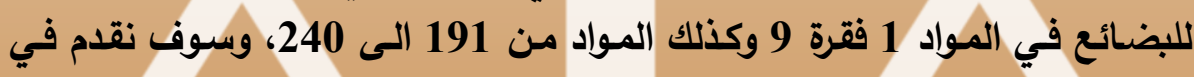

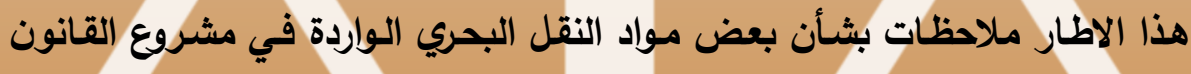

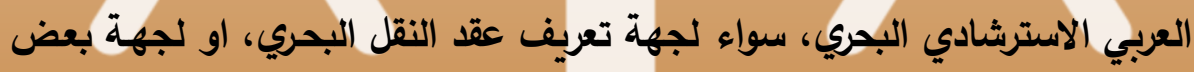

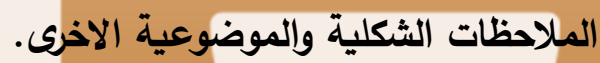

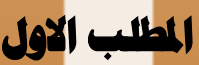

\section{ملامهنات من هيث تعريف مقد النقل البمري}

يعرف عقد النقل البحري للبضائع بأن ذلك العقد الذي يلتزم الناقل بمقتضاه

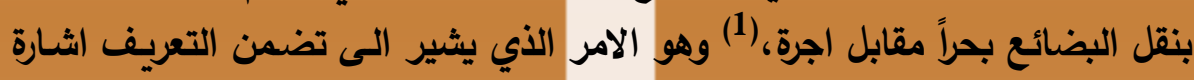

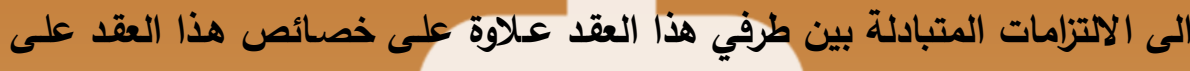

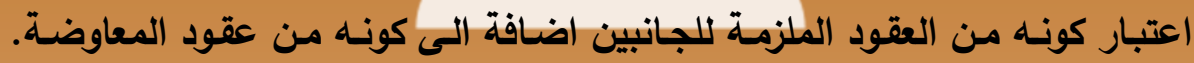

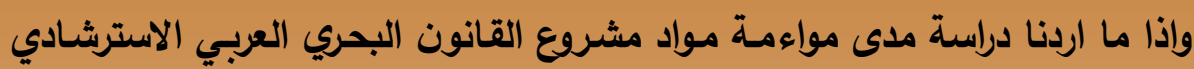

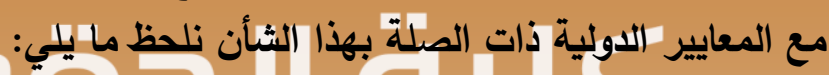

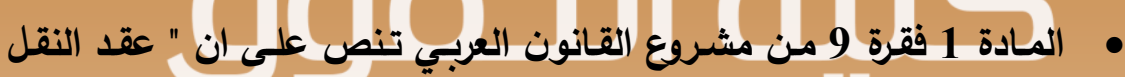

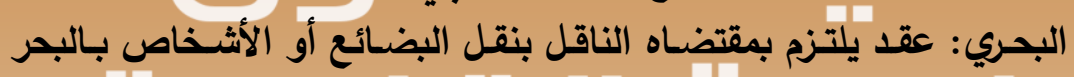

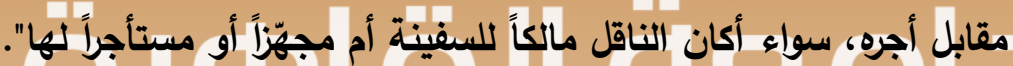
• بينما المادة 1 فقرة 6 من قواعد هامبورغ تنص على ان " يقصد بمصطلح

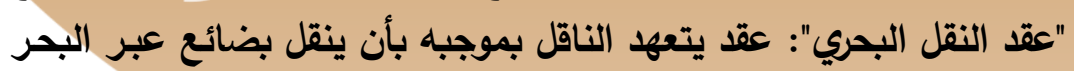

(1) د. عاطف محمد راشد الفقي، النقل البحري للبضائع، دار النهضـة العربيـة، القـاهرة، 1997، ص ص28 وما بعدها. 
من ميناء إلى أخر لقاء أجرة".(1) ثم تضيف قواعد هـامبورغ بـان النقل

$$
\text { يجب ان يكون بين دولتين مختلفتين. }
$$

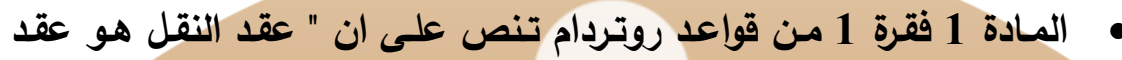

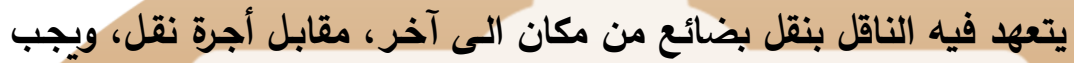

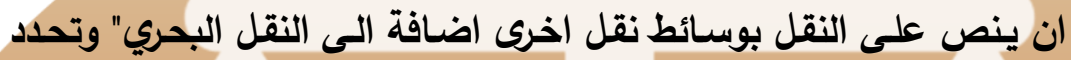

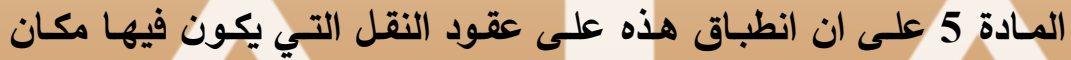

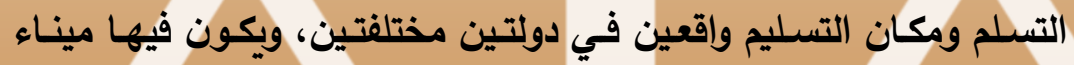
التحميل في عملية نقل بحري وميناء التفريغ في العملية ذاتها واقعين في وني فين دولتين مختلفتين.

والملاحظ ان التعريف الوارد في مشروع القانون البحري لـ يحدد الزامية ان يكون

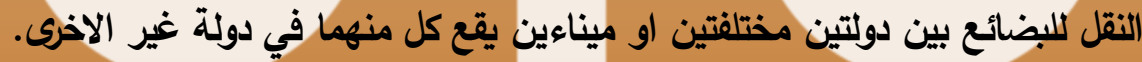

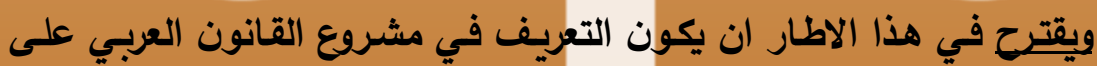

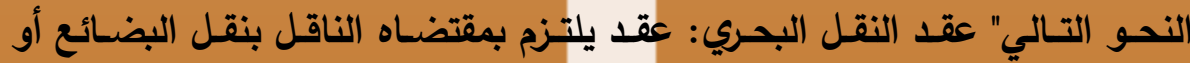

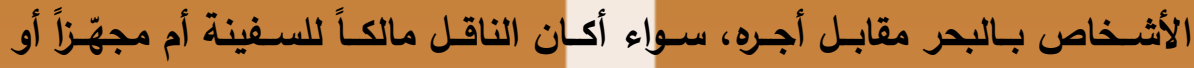

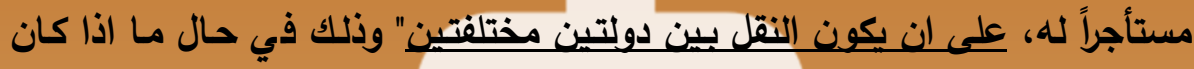
النقل دوليا، او بين ميناءين مختلفين اذا ما كان النقل داخل الدولة الواحدة. والعلة من اقتراح التعديل هو المواءمة مع الاتفاقيات الدولية التي تلتزم بها

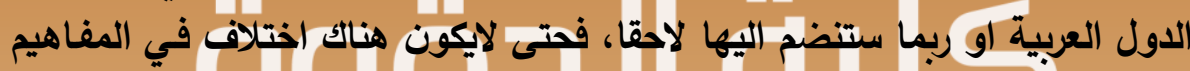

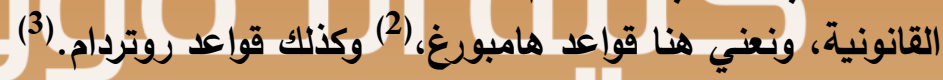

무

(1) الاتفاقية متاحة على الموقع الشبكي لليونسترال

http://www.uncitral.org/uncitral/ar/uncitral texts/transport_goods/Ha

mburg_rules.html

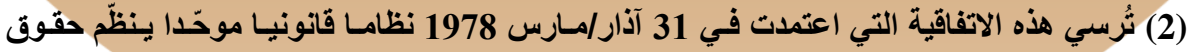

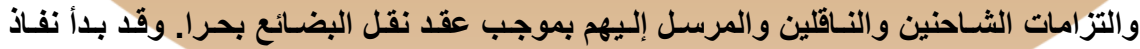

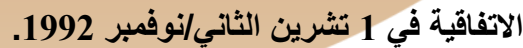

(3) ورد في القانون السوداني " قانون النقل البحى لسنة 2010 " والذي يعتبر من القوانين العربية

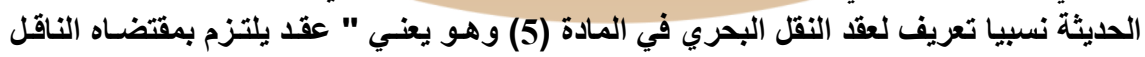




\section{الإلب الثاني

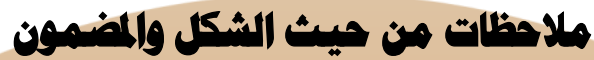

نعرض اولا للملاحظات الثكلية ومن ثم لبعض الملاحظات الموضوعية

\section{الفرع الاول}

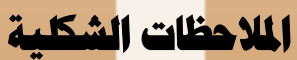

ثمة ملاحظات من حيث الثكل الخاص بتبويب وترتيب النصوص المتعلقة

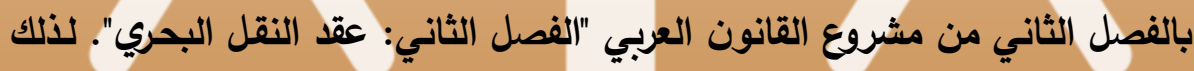

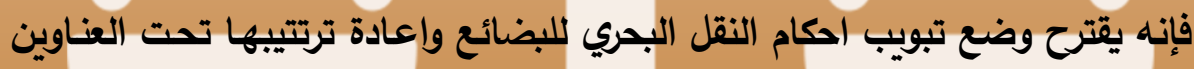
المختارة بحيث تثمل مايلي: أولا: الاحكـام العامـة ( تــنف وتوضـع احكـام الآبـات قربنـة لنقل البضـائع

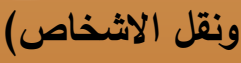

ثانيا: الاحكام الخاصة بنقل البضائع

1- وثائق النقل " مستندات النقل": تثمل المواد 192-193-195-195-196- '-196-

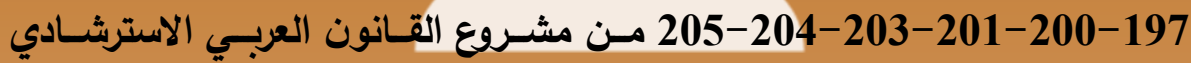

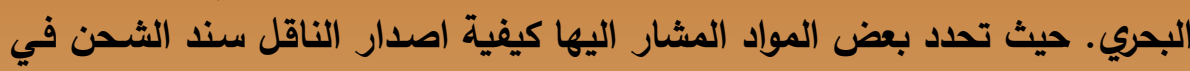

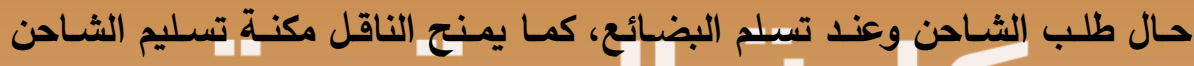

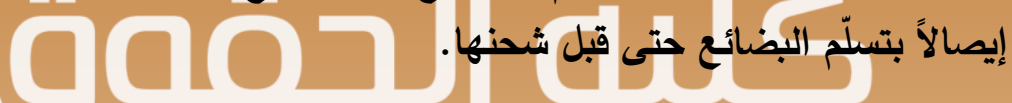
وتشير المواد المذكورة الى احقية الثاحن بطلب ايراد بيان مؤرخ على سند

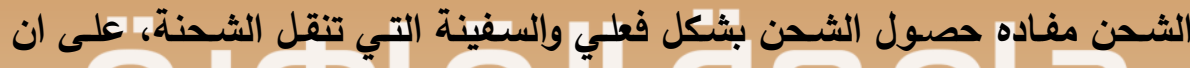
يقدم الطلب من الشاحن الى الناقل.

ويشـترط مشـروع القـانون البحري العربـي الاسترشـادي تـوفر مجموعـة مـن

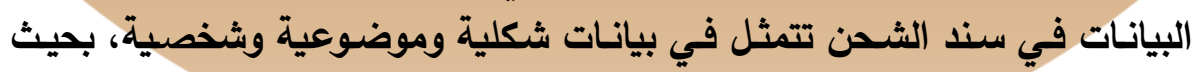

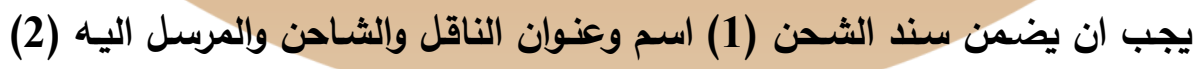

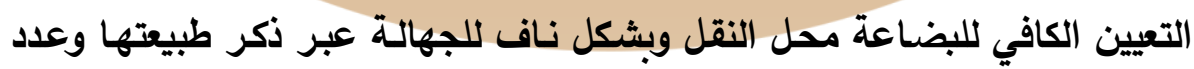

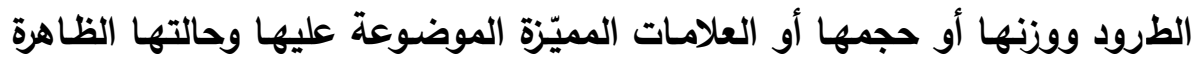


بما في ذلك حالة الأوعية الموضوعة فيها. (3) اسم اداة النقل اي إسم السفينة إذا

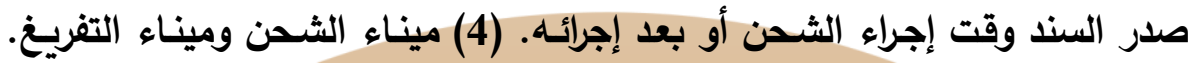

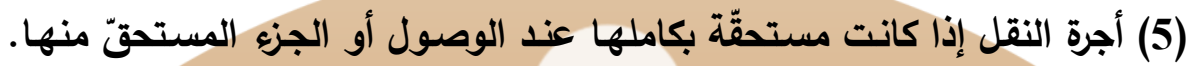

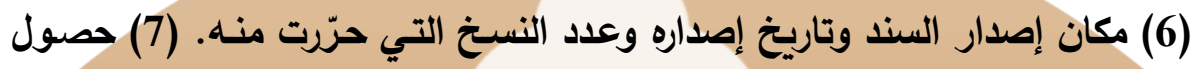

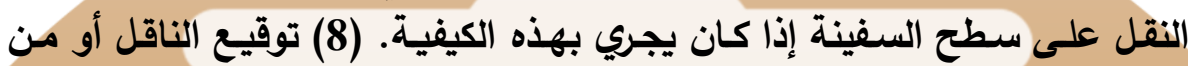

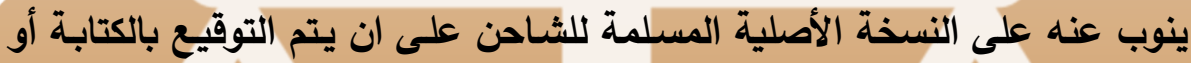

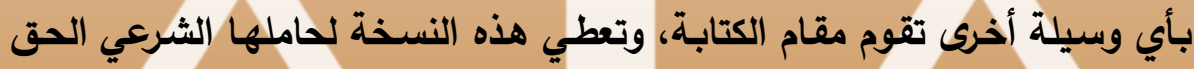

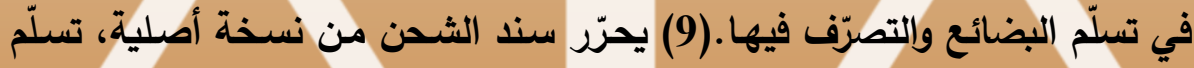

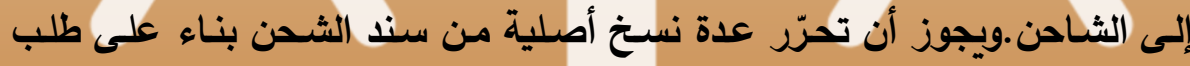

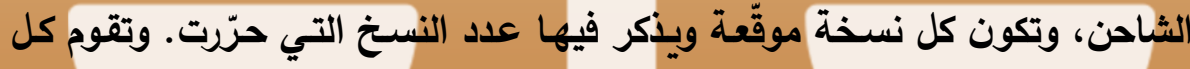

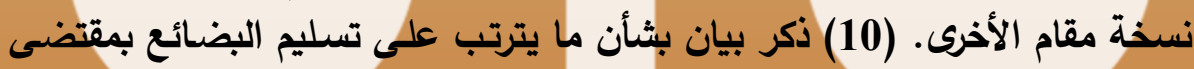

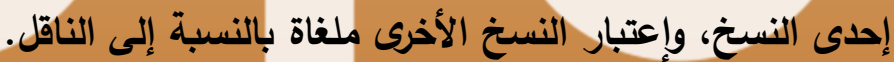

وتتنوع طرق تحرير السند بحسب المشروع العربي، فإما ان يتم تحرير السند

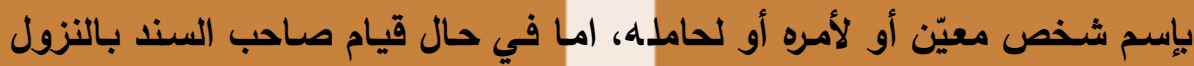

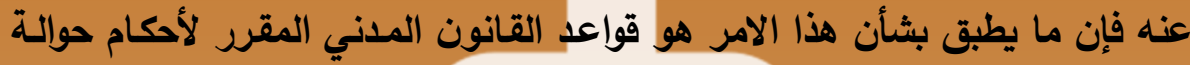

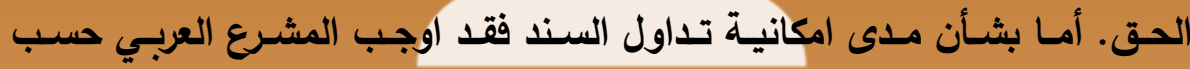

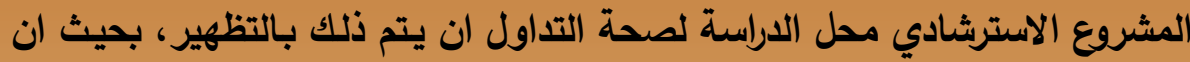

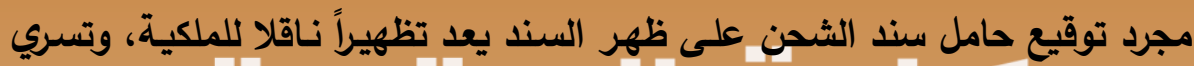

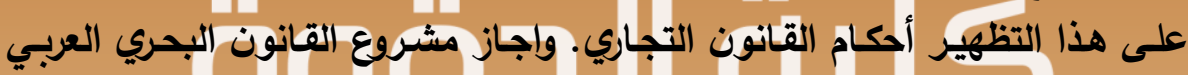
الاسترشادي النصّ في سند الثدن على حظر حوالته أو تداوله.

ومواءمة للتطورات التكنولوجية فقد اعترف المشروع العربي المشار بإمكانية

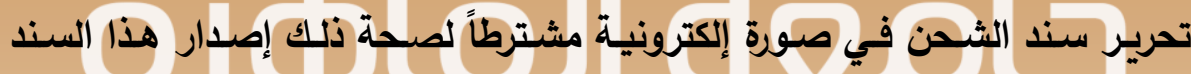

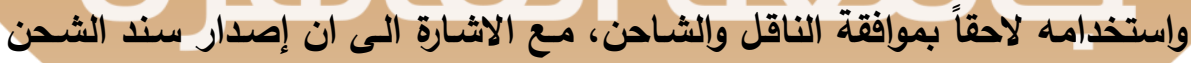

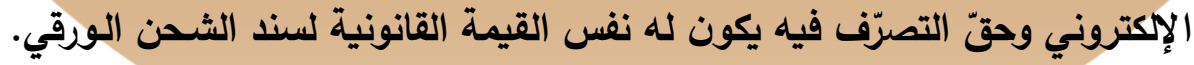

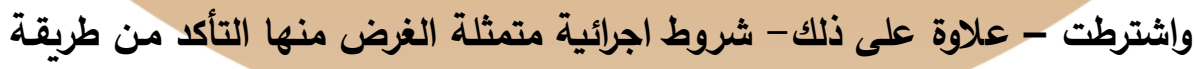

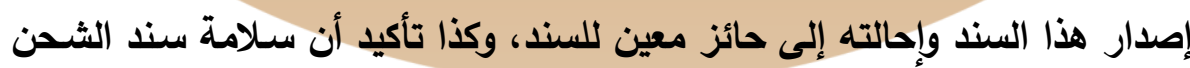

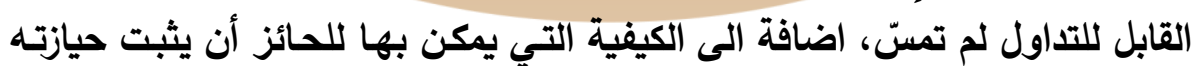




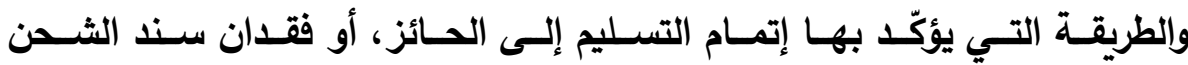

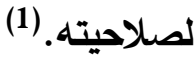

واذا اردنا مقاربة ما اتت به احكام المشروع العربي من تفصيلات وتحديدات

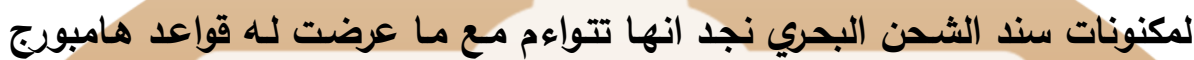

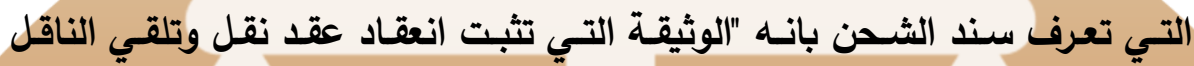

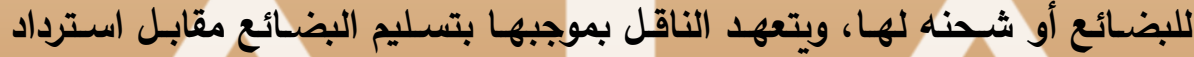

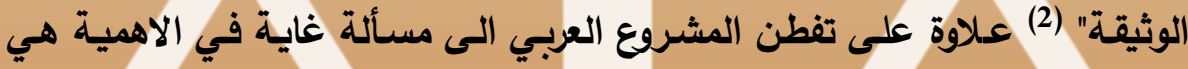

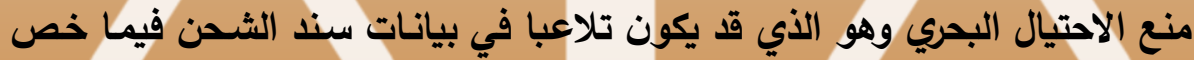

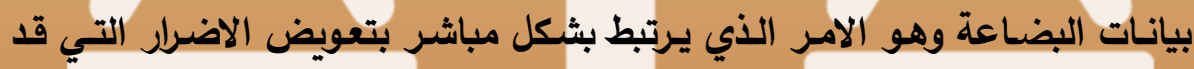

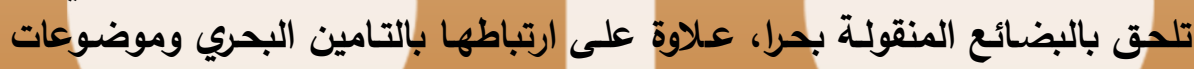

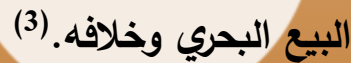

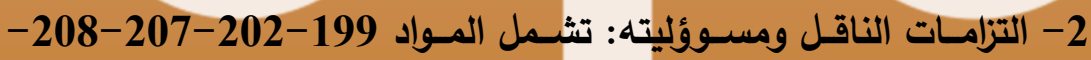

-228-227-226-225-223-222-218-217-216-211-210-209

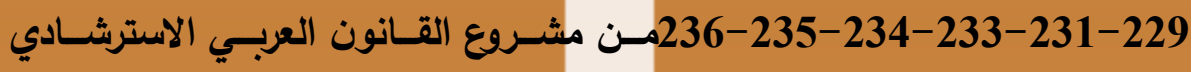

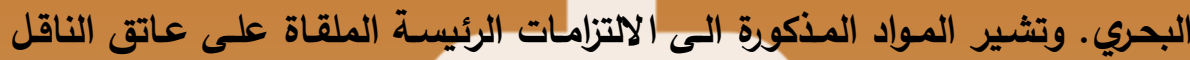
بموجب عقد النقد وكذلك انعقاد مسؤوليته.

أ. التزام الناقل طيلـة مراحل الرحلـة البحربـة وقبلهـا، ببـذل العنايـة الواجبـة

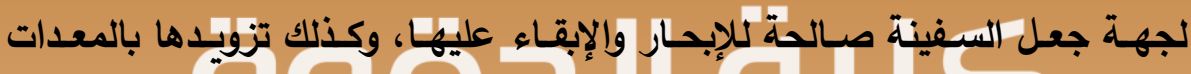

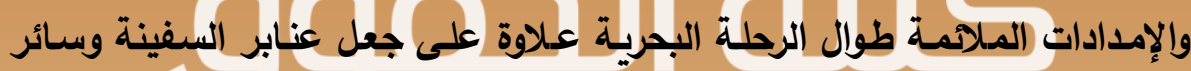

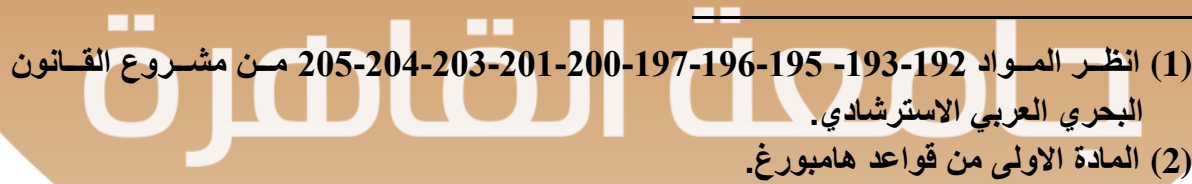

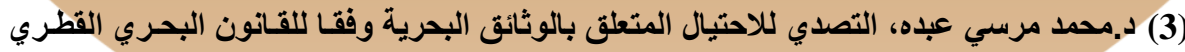

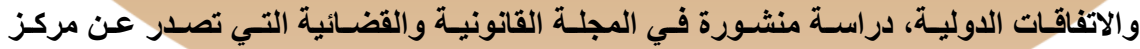

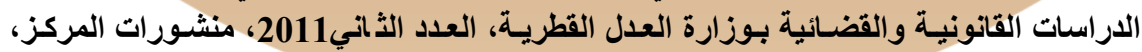
الدوحة، 2011، متاح الكترونيا على وانى http://www.almeezan.qa/ReferenceFiles.aspx?id=63\&type=doc\&language= ar.155 ص 
العربي الاسترشادي البحري 2016

أجزائهـا التـي تنقل فيها البضـائع، ومـا يـوفّره الناقل مـن حاوبـات مخصصــة لنقل

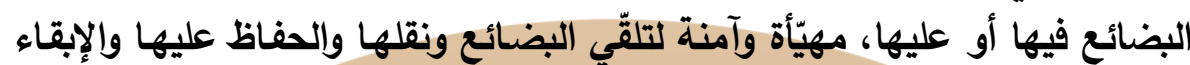
عليها كذلك.

ب. التزام الناقل بشعن ورص ونقل البضائع في السفينة وتفريخغ البضـائع مـا

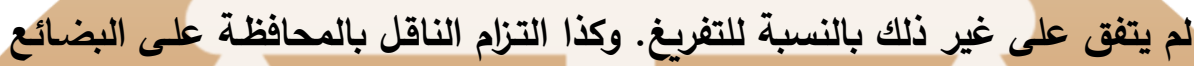
المشحونة على السفينة.

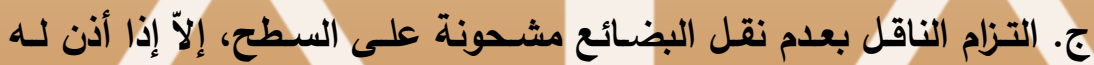

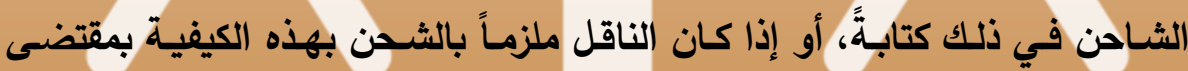

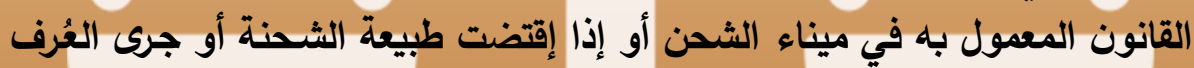

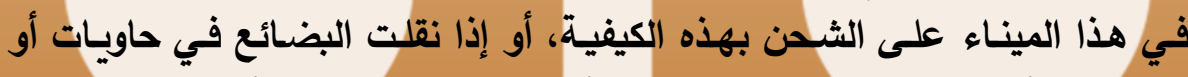

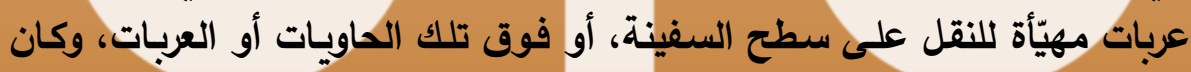

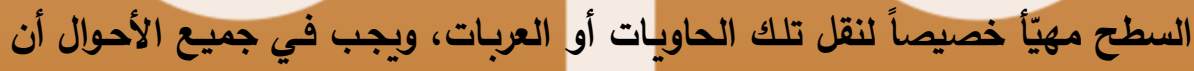

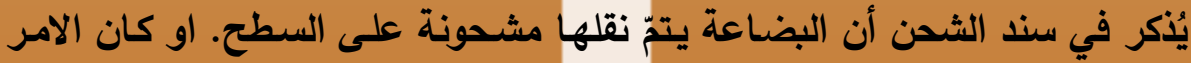
متعلقاً بالملاحة الساحلية.

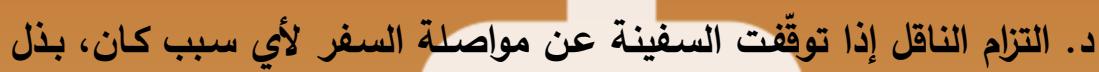

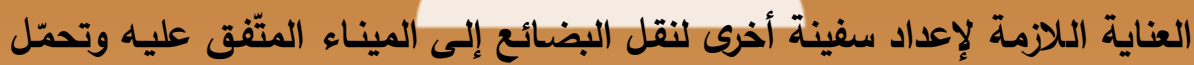

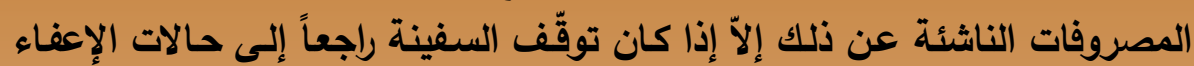
هـ التزام الناقل بتفيذ التعليمات الصادرة إليه مدّن له الحقّ في إصدارها؛ ضمن الدود والضوابط القانونية والاتفاقية. و. التزام الناقل أو من ينوب عنه بتسليم البضائع عند وصولها إلى الحامل الشرعي لسند الشحن أو من ينوب عنه في تسلّمها.

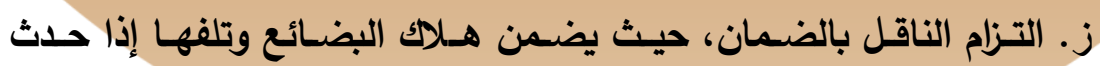

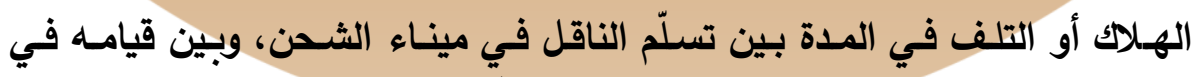

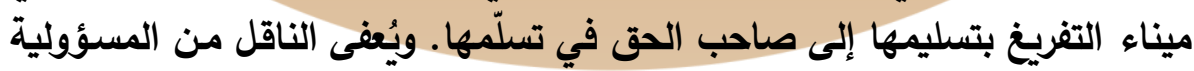

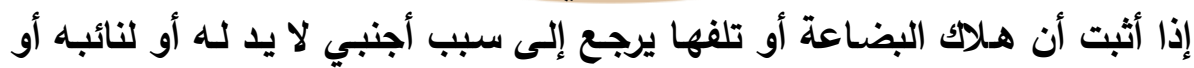


لأحد من تابعيه فيه، علاوة على عدم مسؤولية الناقل عن هـلاك أو تلف البضائع

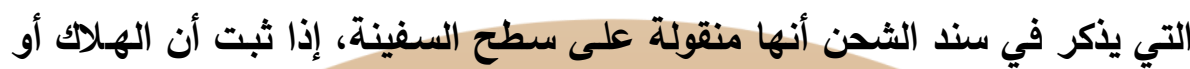

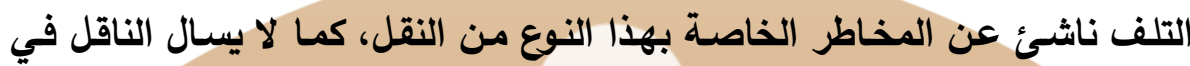

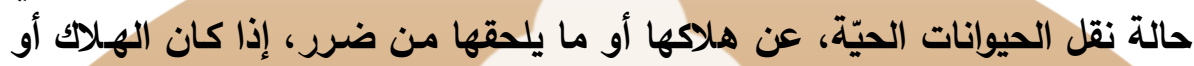

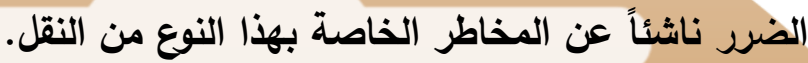
وتقر الاحكام التي وضعها المشروع العربي بطلان كل إتفاق يتمّ قبل وقوع

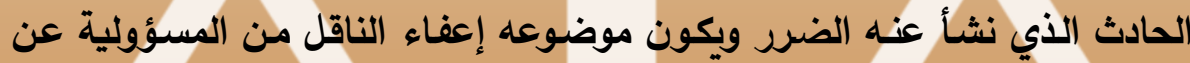

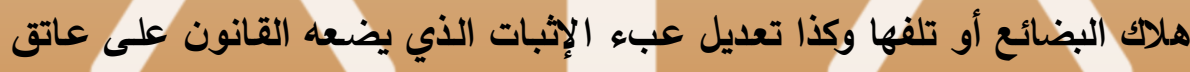

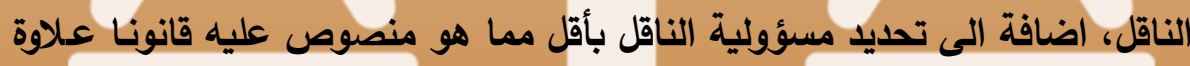

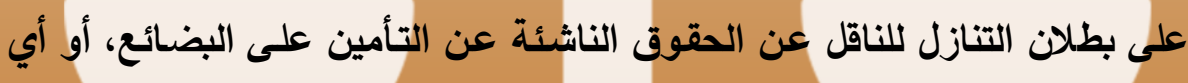

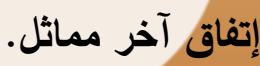

ويسأل الناقل عن التأخير في تسليم البضـائع، إلاّ إذا أثبت أن التأخير يرجيع

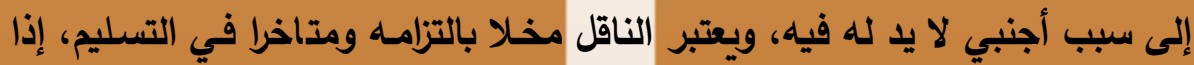

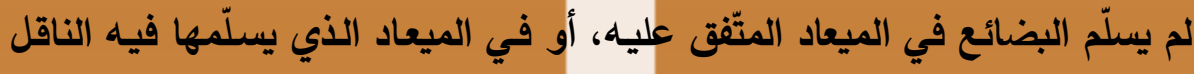
العادي في الظروف المماثلة، إذا لم يوجد مثل هذان المئ الإتفاق.

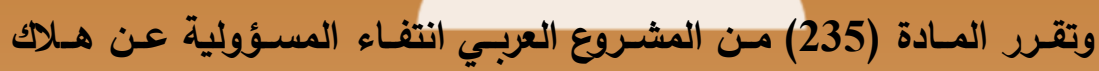

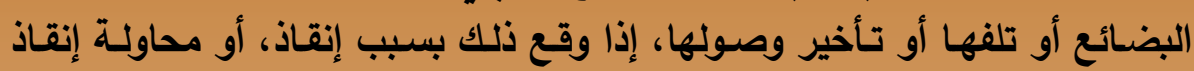

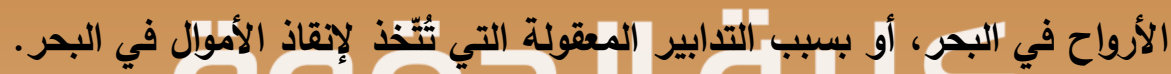
وفي مقاربة ما تم ذكره من الناحية الشكلية في المشروع العربي مـع المعايير

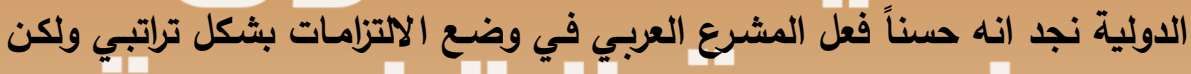

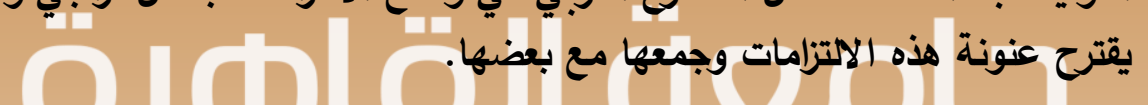

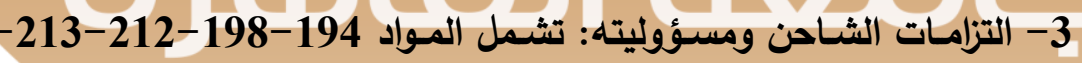

$$
\text { 214-217-215-217 من مشروع القانون العربي الاسترشادي البحري. تئيمل. }
$$

وضـع صـائغو مشروع القانون البحري العربي الاسترشـادي ضمن مواد هذا المشروع مجموعة من الالتزامات الملقاة على عاتق الشاحن تمثلت بالتالئي: 
أ. التزام الثاحن بتسليم البضائع للناقل في الزمـان والمكان المتّفق عليهمـا،

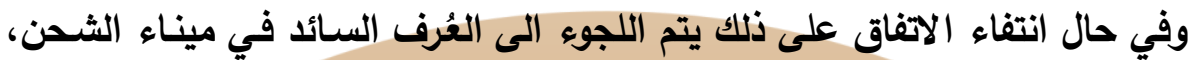

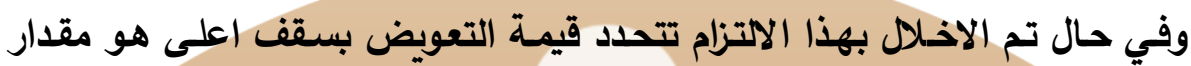

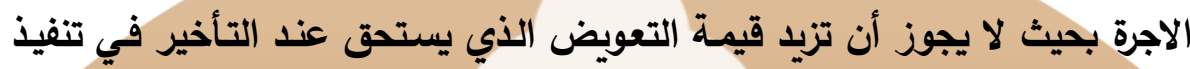
هذا الإلتزام على مقدار الأجرة.

ب. التزام الثـاحن تسليم البضائع للناقل جاهزة للنقل وبحالـة تكفل تحمّلها

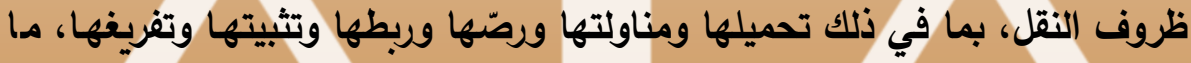
لم يتّفق على خلاف ذلك. وأن لا تسبّب أذى للأثخاص أو ولى الممتلكات.

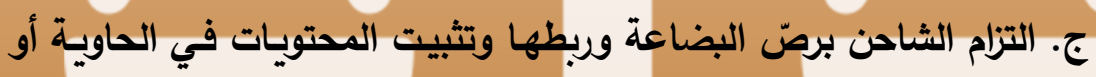

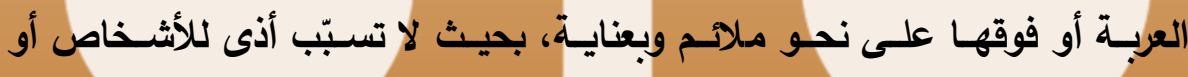
الممتلكات.

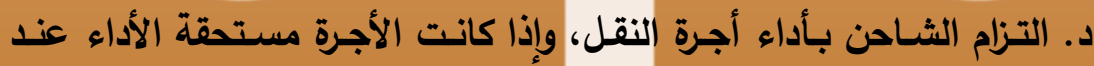

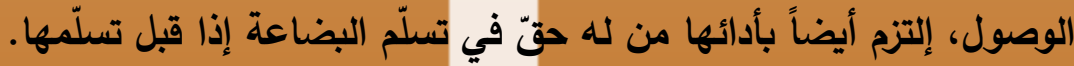

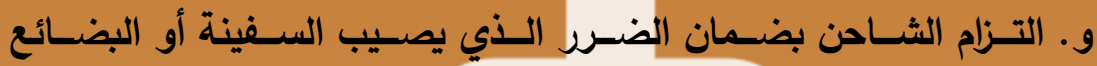

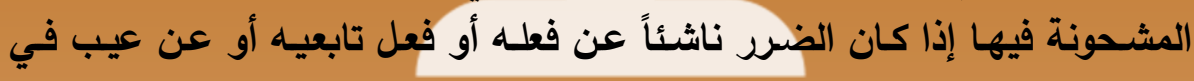
بضائعه. وشكلياً فإن ترتيب الاتزامات المتعلقة بالثاحن اتي منقياً وبعد ذكر التزامـات

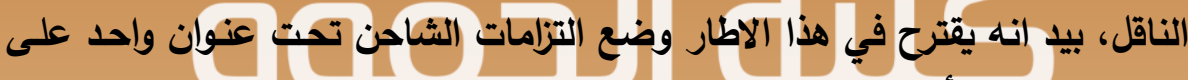
غرار المقترح بشأن التزامات الناقل.

4- احكام اخرى متعلقة بالتسلم والتسليم: تشمل المواد: 206-219-220-2 232-230-21 من مشروع القانون العربي الاسترشادي البحري. وفي هذا الاطار فإنـه يقترح ترتيب المواد المشـار اليها تحت عنوان الاحكام

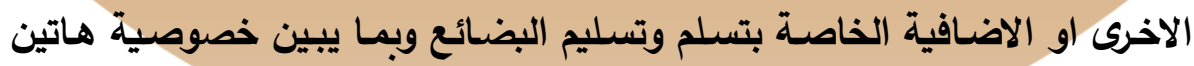
العمليتين بالنسبة لعقد النقل البحري للبضائع. 5- دعـاوى المسؤولية:تشـمل المـواد 237-238-239-240 مـن مشـروع 


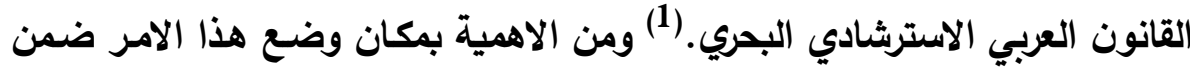

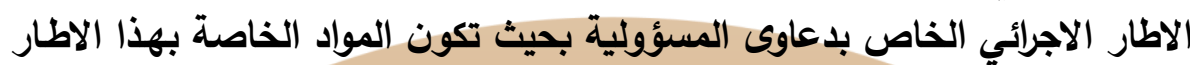
مرتبة خلف بعضها وتحت العنوان الخاص بلدعاوى المسؤولية.

\section{الانغع الثنزي}

\section{المالامشظات الموضوفية}

نركز في هذا الاطار على بعض الملاحظات الخاصة بمسؤولية الناقل البحري

للبضائع أولا: هم المسؤولية

يُلقـي عقد النقل الدولي البحري للبضـائع بعدة التزامـات على عـاتق الناقل

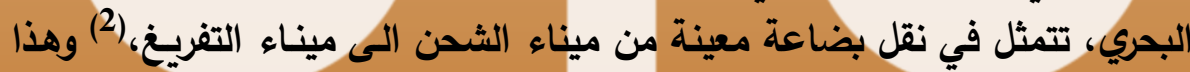

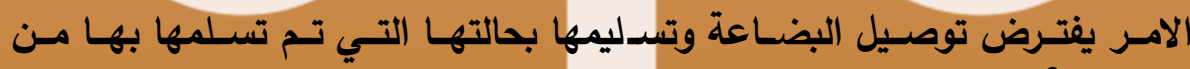

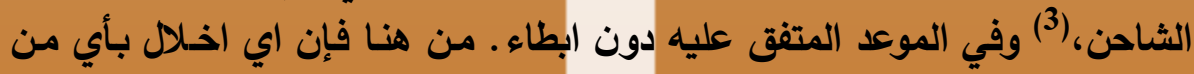

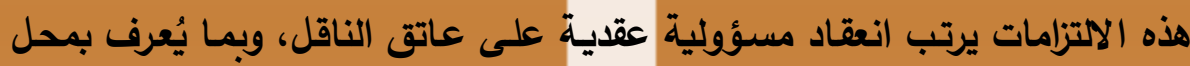

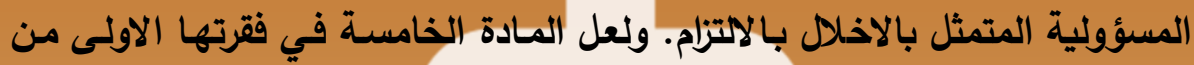

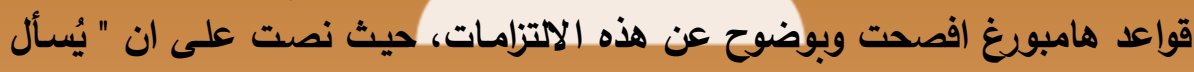

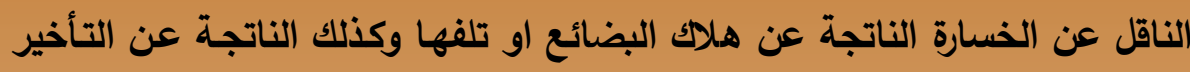

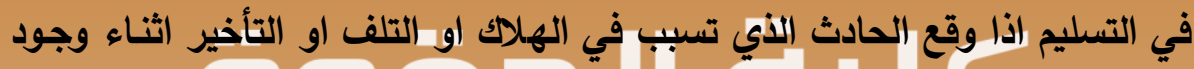

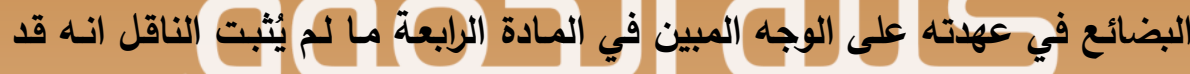

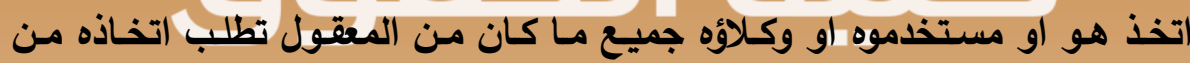

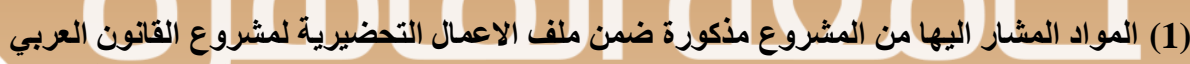

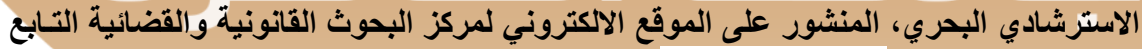

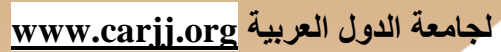

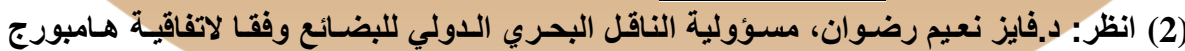

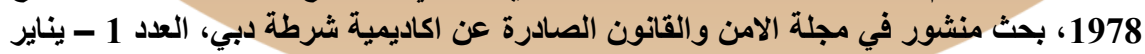

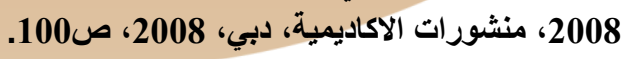

(3) د.حسين النوري، دراسات في القانون التجاري البحري، مكتبة عين شمس، القـاهرة، بدون ذكر 
امـا مشروع القـانون العربي فقد نص في المـادة (222) منسه على ان " 1. يضمن الناقل هلاك البضائع وتلفها إذا حدث الهـلاك أو التلف في المداة بين فين تسلّم

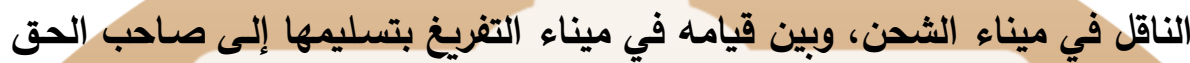

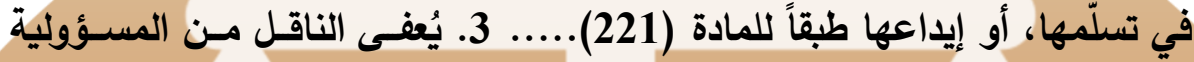

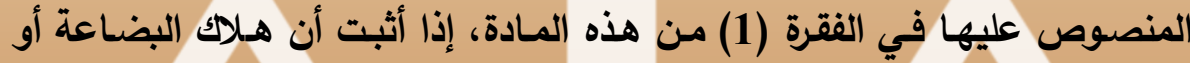

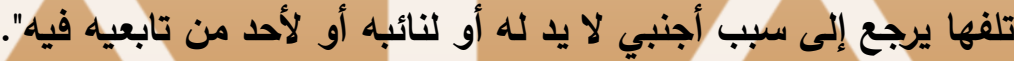

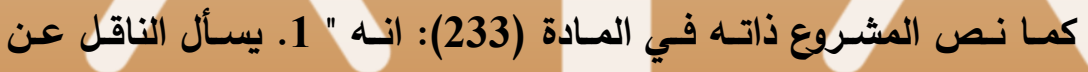

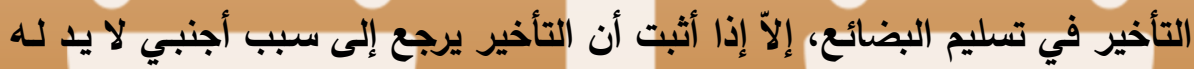

ويلاحظ في هذا الشأن ان المشروع العربي عرض بالنسدبة لمسؤولية الناقل

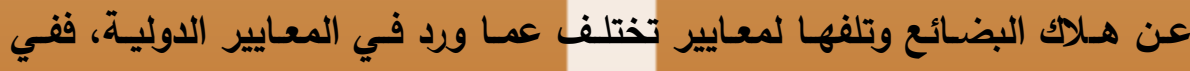

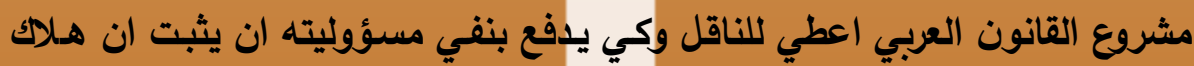

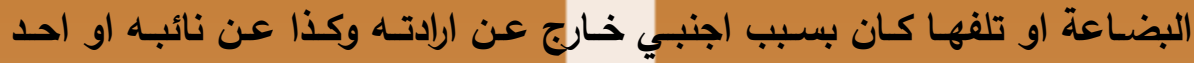

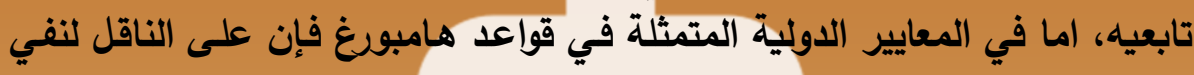

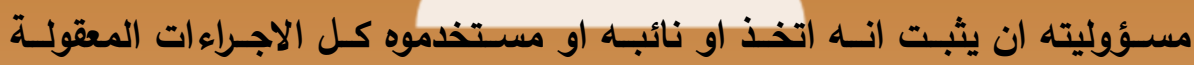

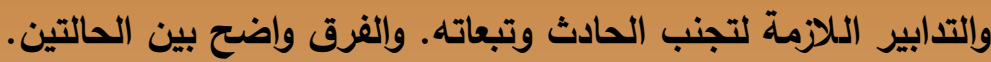

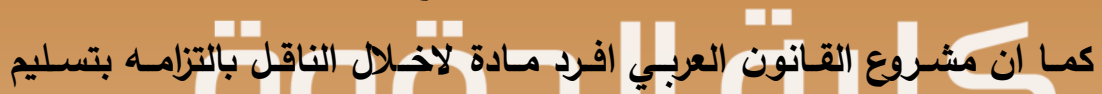

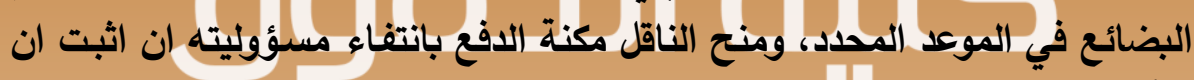

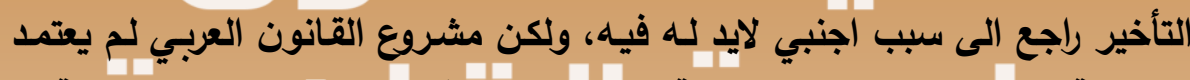

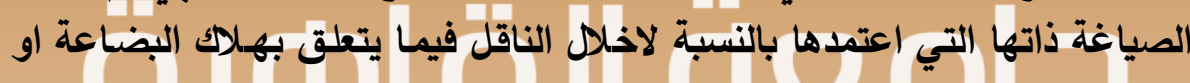

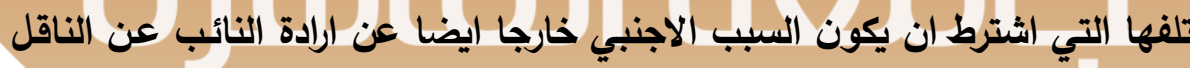
وكذلك تابعي الناقل. والاقترح في هذا الاطار اهران: 1- اعتمـاد نص قواعد هامبورغ بالنسبة لالتزام الناقل وضرورة تطلب قيامـه بالتدابير والاجراءات المعقولة لتجنب الحادث وتبعاته. 
2- توحيد الحلول القانونيـة في مشروع القانون العربي الخاصـة بالتأخر في

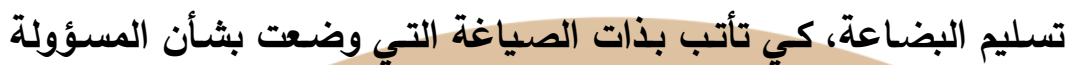

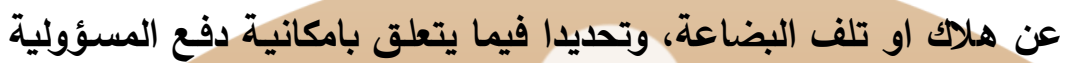
باثبات السبب الاجنبي الخارج عن ارادة الناقل او وكيله او تابعياهيه. وللتوضيح فإن صور الاخـلال بالالتزامـات الملقاة على الناقل البحري كمحل

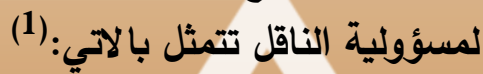

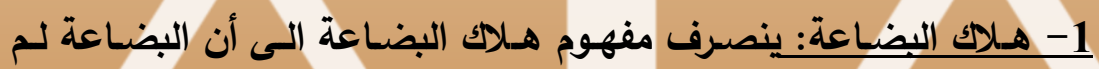

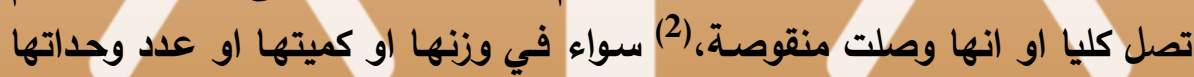

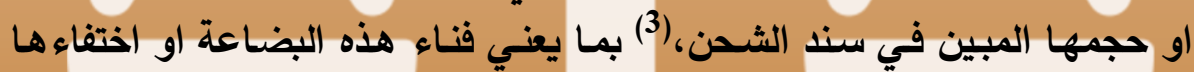

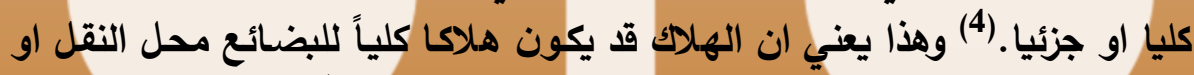

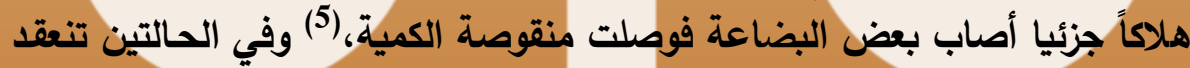

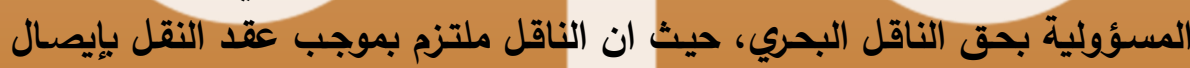

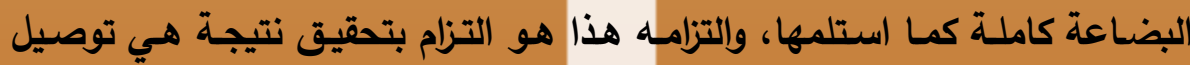

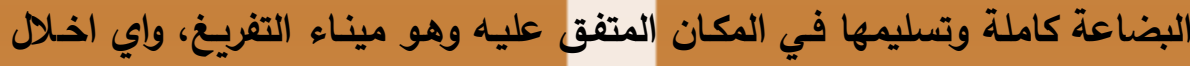

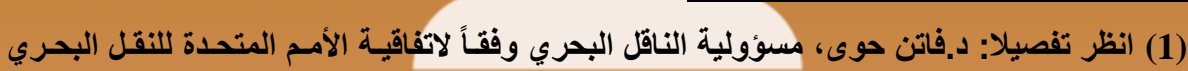

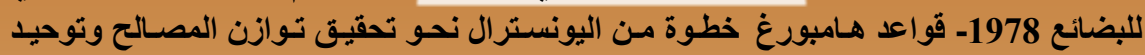

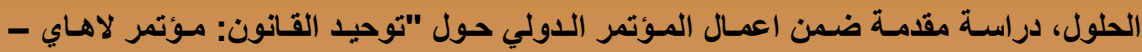

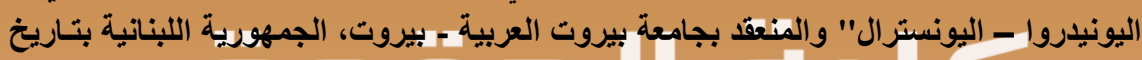

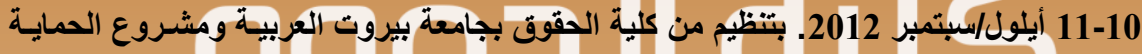

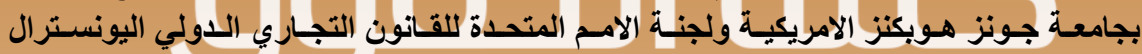
و اليونياروا ومؤتمر لاهاي.

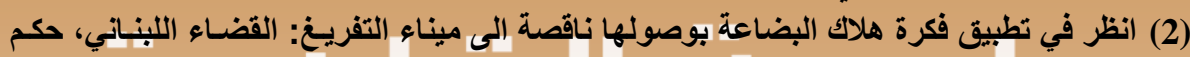

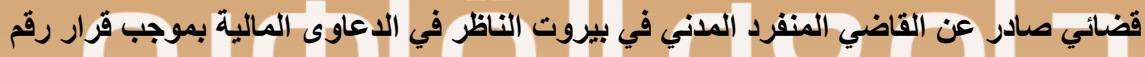

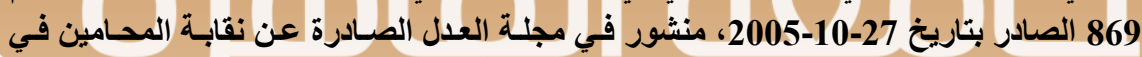

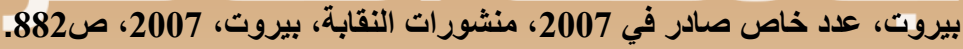
(3) انظر اساتنتا د.محمد العريني و د.محمد الفقي، قانون النقل، منشورات الحلبي الحقوقية، بيزوت،

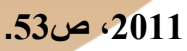

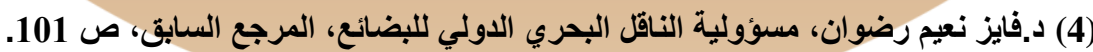

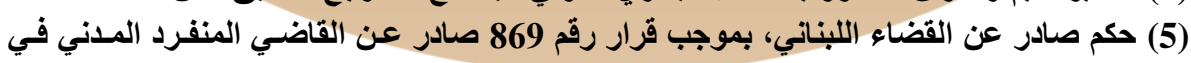

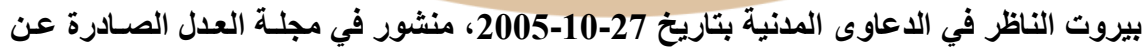

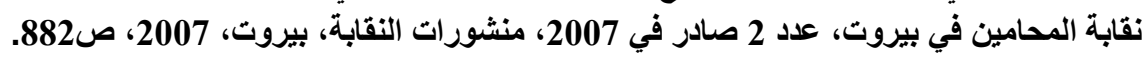


بمتضمنات هذا الالتزام يرتب مسؤولية عقدية.

بيـان ان هنالك نـوع مـن الهـلاك اليسير لجزي مسن البضـاعة، وهـو نـوع مـن

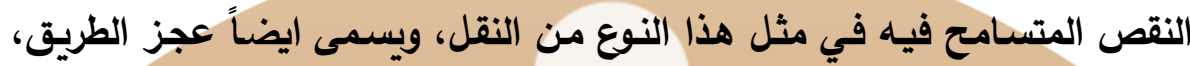

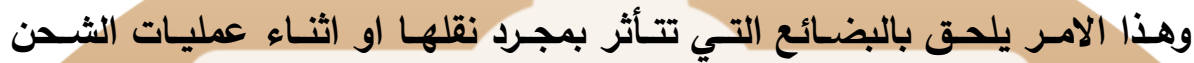

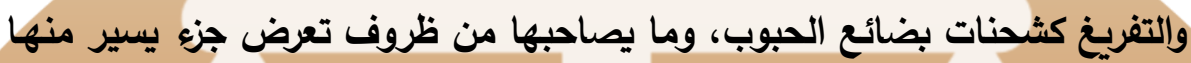

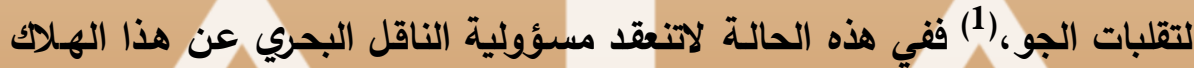

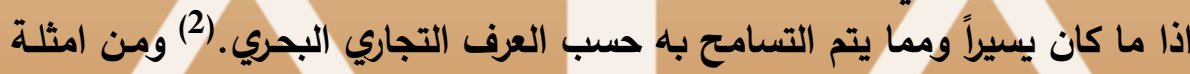

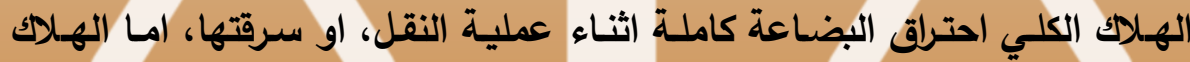
الجزئي فمثاله احترلق جزه من البضائع وبقاء جزء منها بحالة سليمة. وهنا يثور التساؤل حول المُكلّف بإثبات وقوع هذا الهـلاك، وتكمن الاجابة

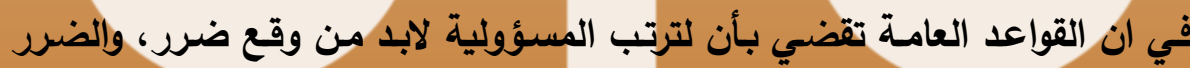

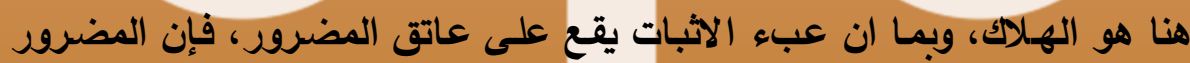

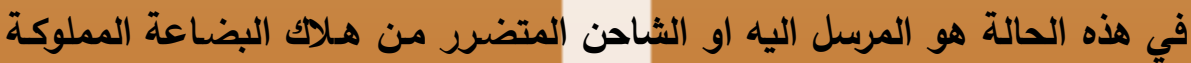

2- تلـف البضــاعة: يفترض تلـف البضــاعة لاعتبارهـا صـورة مـن صـور

الاخلال بالتزام الناقل البحري ان يكون الناقل قد تسلم البضاعة من الشـاحن بحالة

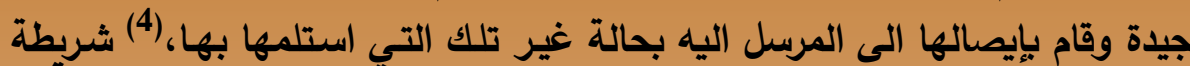

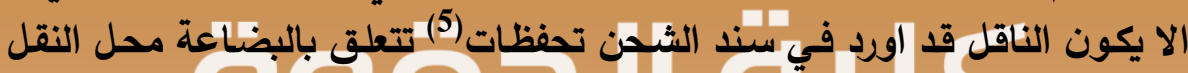

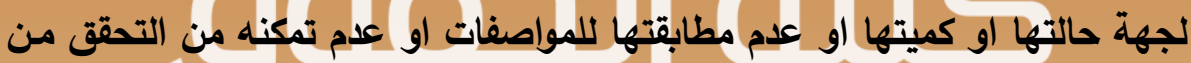

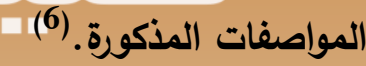

(1) د. مصطفى كمال طه، القانون البحري، دار المطبو عات الجامعية، الاسكندرية، 2000، ص328.

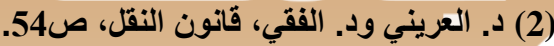

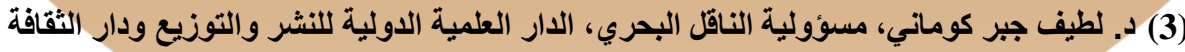

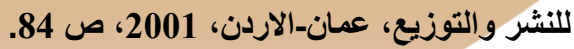

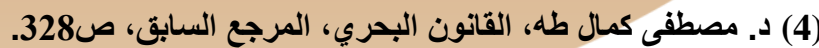

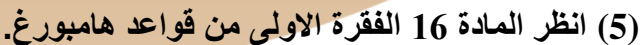

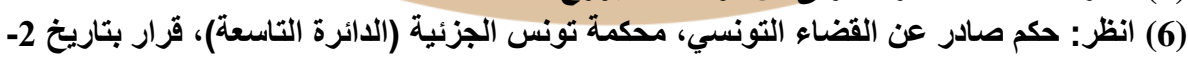

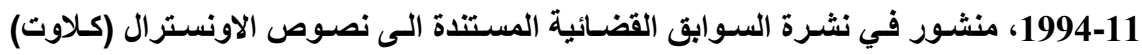


وهذا يعنـي ان المقصسود بتلـف البضـاعة او تعيبها هـو وصـولها كاملـة او

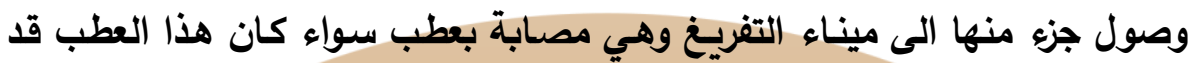

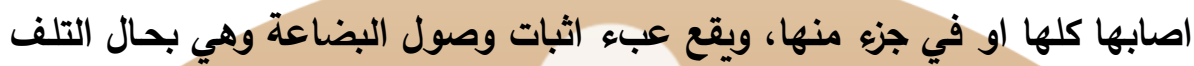

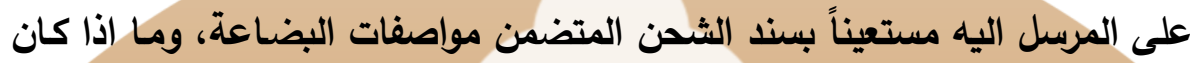

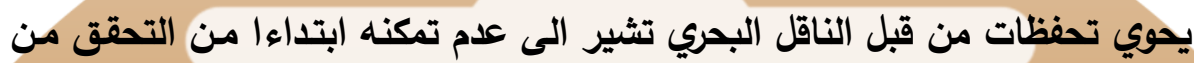

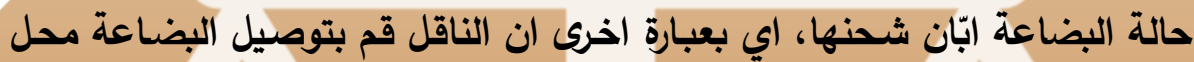

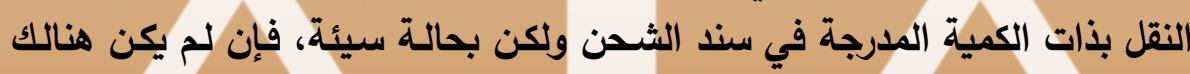

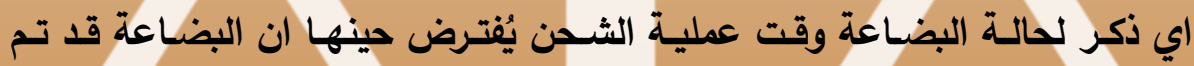

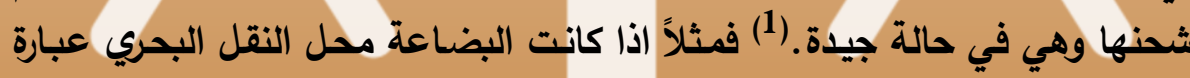

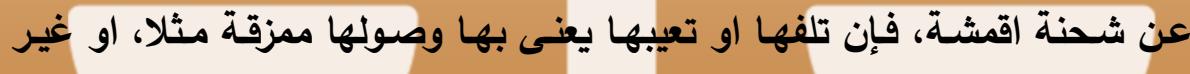

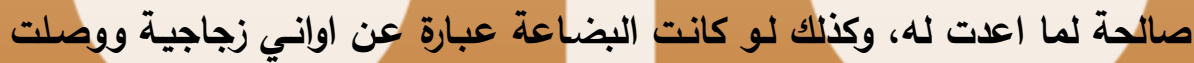

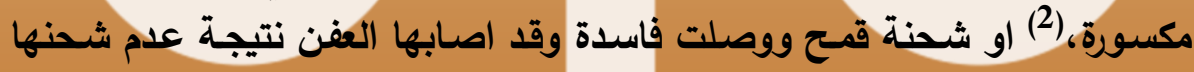

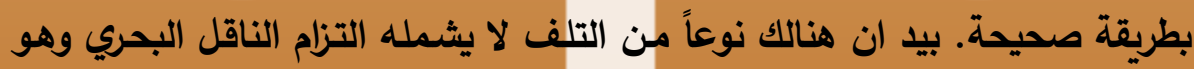

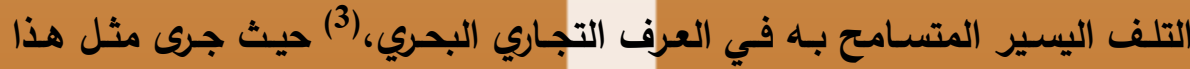

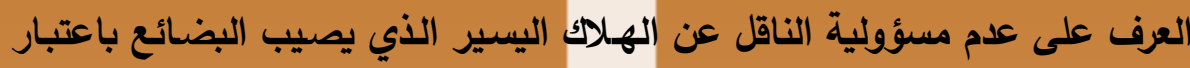

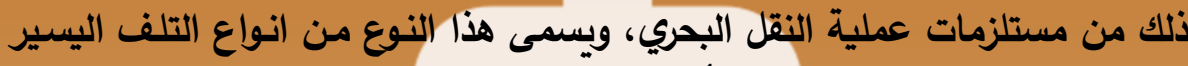
"هدر الطريق" او "عجز الطريق".(4) معلية النقل البحئ

3- تأخير وصول البضاعة: بموجب عقد النقل البحري يلتزم الناقل بإيصال

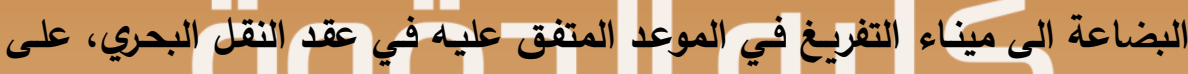

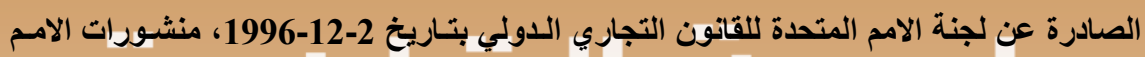

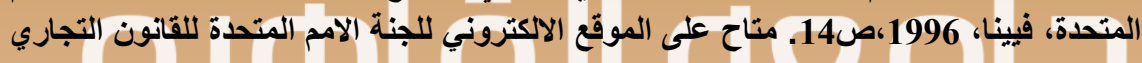

http://www.uncitral.org/clout/searchDocument.do

الدولي "اليونسترال فينا،

(1) انظر في مفهوم تلف البضاعة: د.فايز رضوان، القـانون البحري، منشورات كلية شرطة دبي،

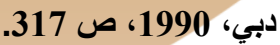

(2) دـ هشام فرعون، القانون التجاري البحري، منشورات جامعة حلب ـ كلية الحقوق، حلبـ سوريا،

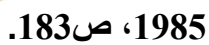

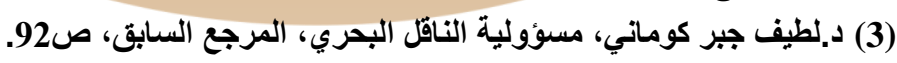

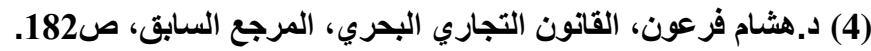


ان يتم التسليم الى من لله الحق في تسلم البضاعة، (1) وفي حال غياب مثل هذا

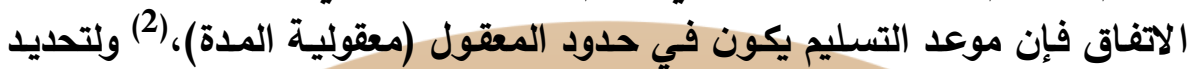

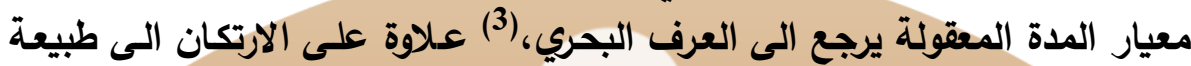

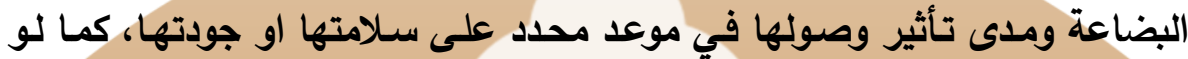

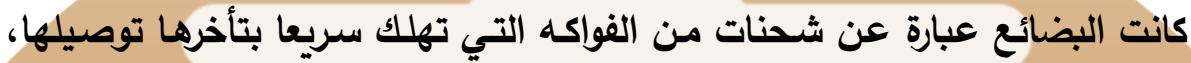

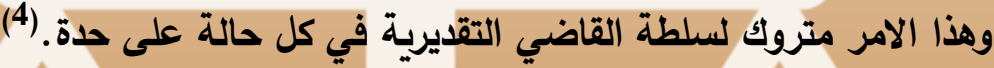

\section{المبحث الهاني}

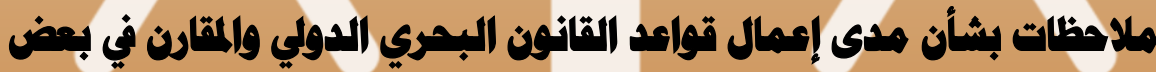

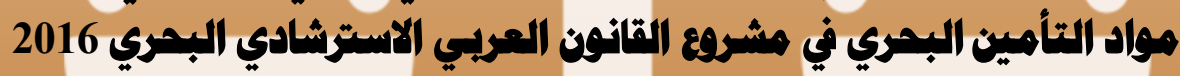

نعرض في هذا الاطار ببعض الملاحظات بثـأن بعض مواد التأمين البحري

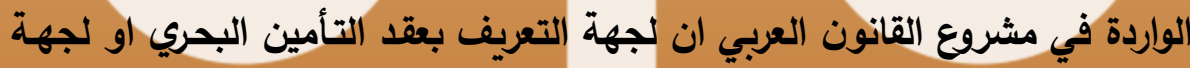
بعض الملاحظات الثكلية و الموضوعية الاخرى.

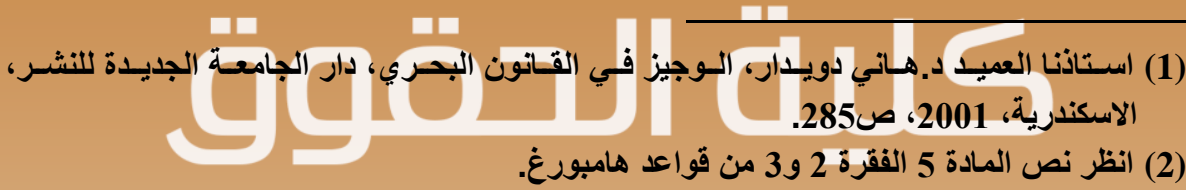

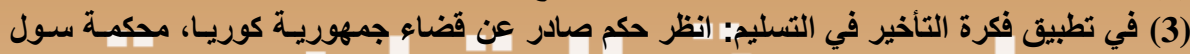

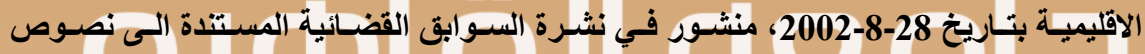

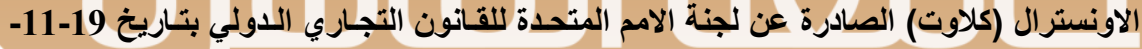

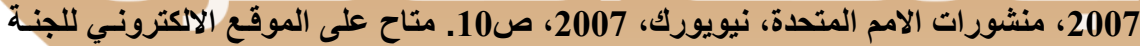

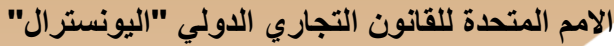

http://www.uncitral.org/clout/searchDocument.do

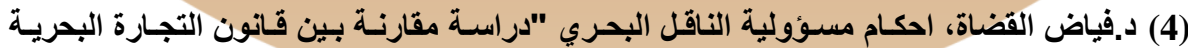

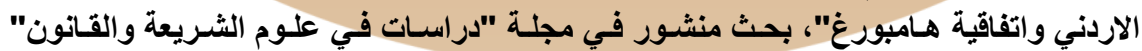

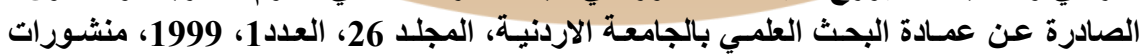

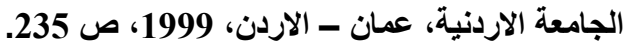




\section{الإطلب الاول}

\section{هلاومنات من هيثث تعريف عقد التامين البمري}

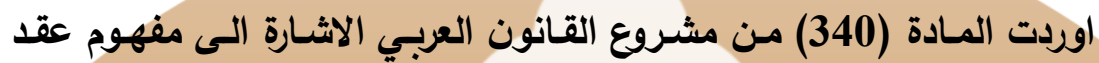

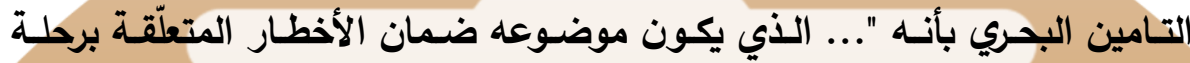

\section{بحرية".}

بيـ ان هذه الاشـارة بحاجة الى مزيــ من التحديد الذي يستطيع من خلاهله

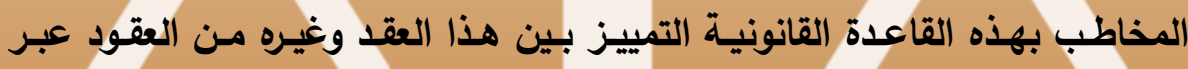

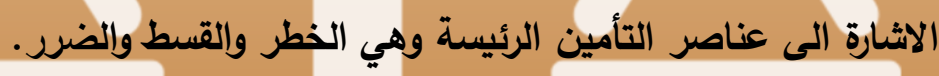

وبالرجوع الى المعايير الدولية، نجد عدم وجود تعريف واضـح لهذه المسألة،

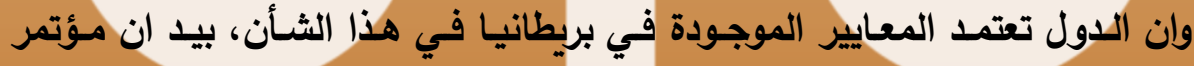

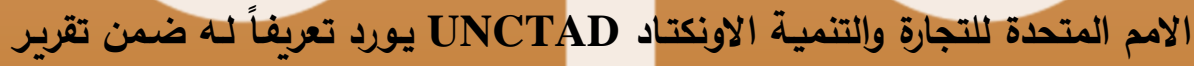

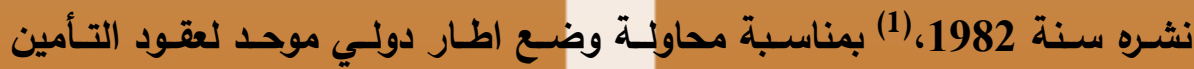

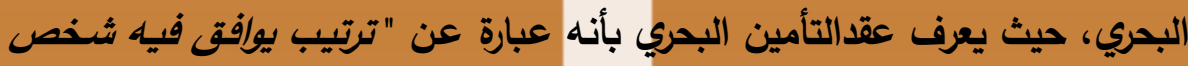

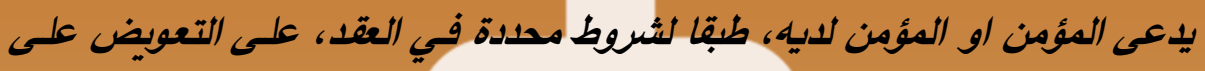

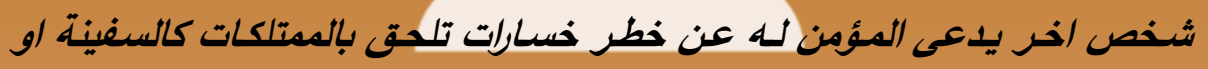

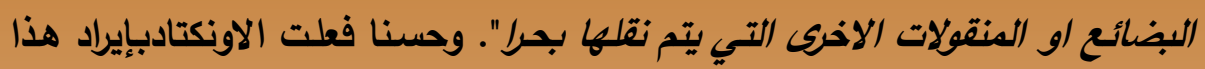

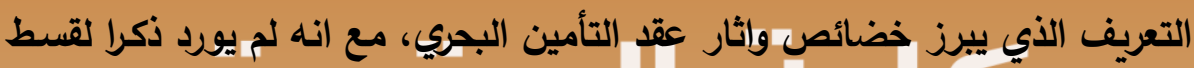
التامين واحال بثأنه الى شروط العقد. لذلك فإن المقترح وضع تعريف دقيق لعقد التأمين البحري.
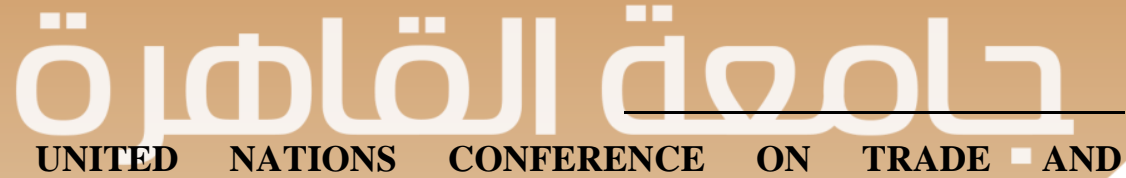

(1) UNITED NATIONS CONFERENCE ON TRADE AND DEVELOPMENT (UNCTAD), Legal and documentary aspects of the marine insurance contract, Report by the UNCTAD secretariat, UN, New York, 1982. Available on line at: http://unctad.org/en/PublicationsLibrary/c4isl27rev1 en.pdf (2) الامم المتحدة، الاونكتاد، الجوانب القانونية والوثائقيـة لعقود التـامين البحري، منشورات الامـم 
ويقترح ان يكون تعريف عقد التأمين البحري على النحو التالي:

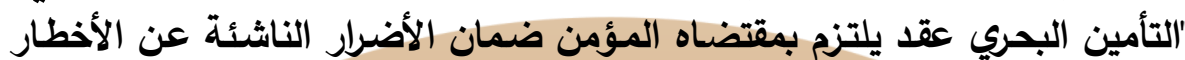
البحرية مقابل قسط مالي معين يؤديه المؤمن له. له.

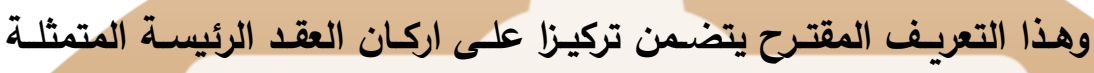

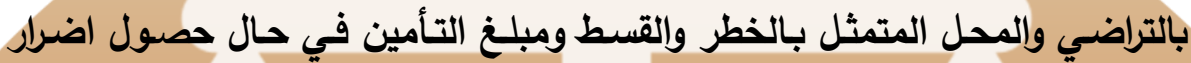
ناشئة عن خطر بحري.

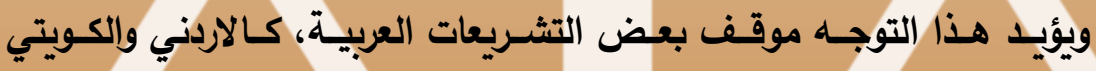

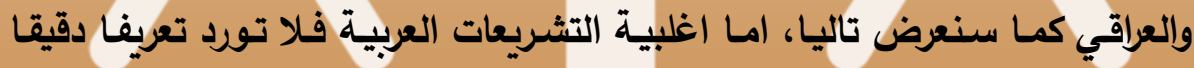
لعقد التامين ومبينا لخصائصه المميزة له عن غيره من العقود.

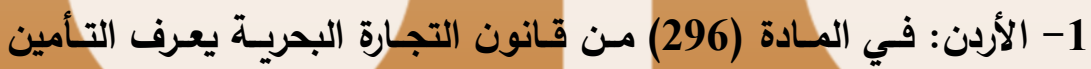

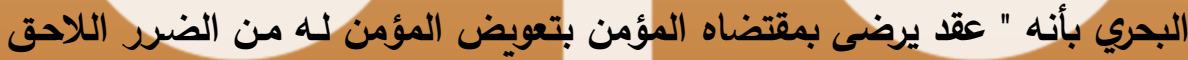

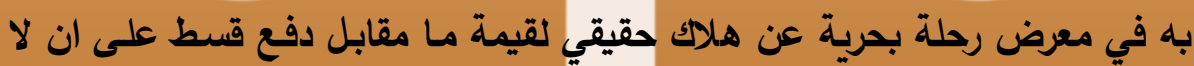

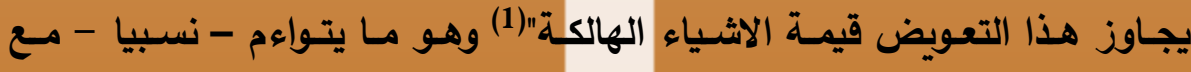

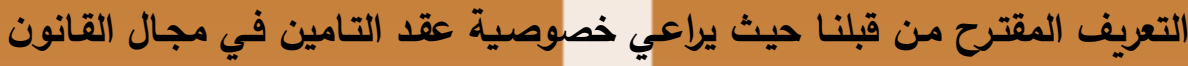
البحري وكذلك خصائصه.

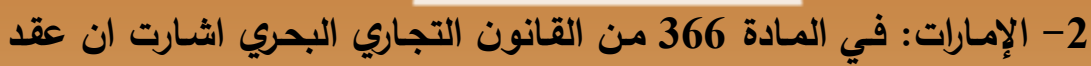

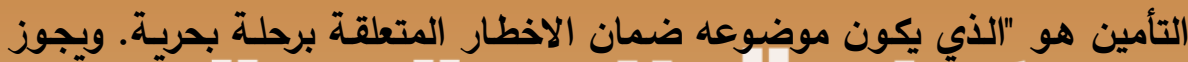

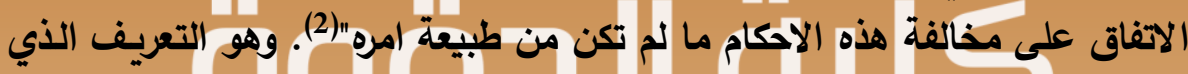

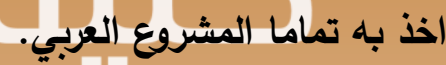

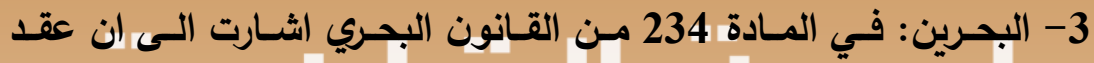

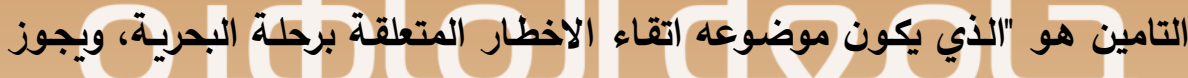

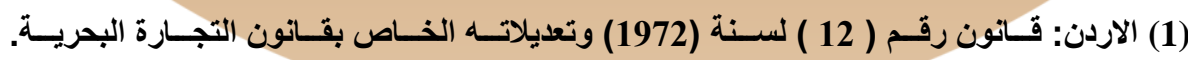
http://www.lob.gov.jo/AR/Pages/AdvancedSearch.aspx

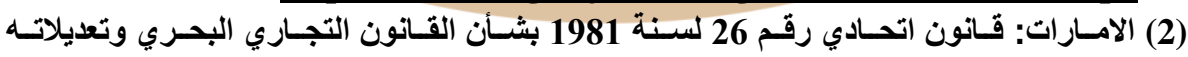
http://www.elaws.gov.ae/ArLegislations.aspx 
الاتفـاق علـى مخالفـة هذه الاحكام الا اذا كانـت ذات صـفة الزاميـة" (1) وهـو ذات التعريف تقريبا الذي اخذ به المشروع العربي والتقانون الاماراتي.

5- السـودان: في المـادة 163 مـن قـانون النقـل - ويعتبر مـن القـوانين

الحديثة عربيا حيث صدر في 2010 - عرف عقد التأمين بأنه " عقد يلتزم بموجبه ولفيه

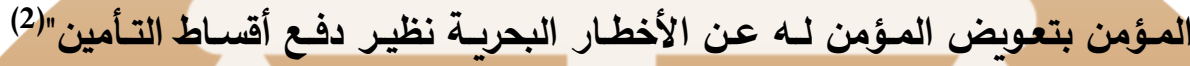

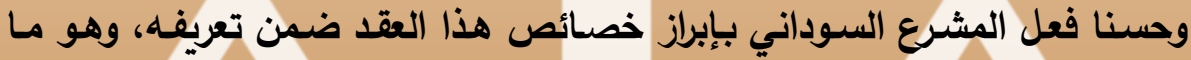

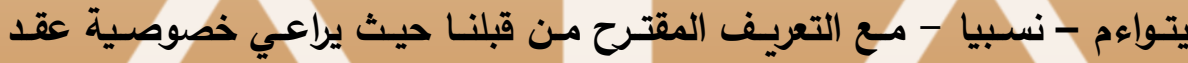
التامين في مجال القانون البحري وكذلك خصائصه.

5- العرلق: في المـادة 175 من قانون التجارة العثـاني الذي لازال سـاريا

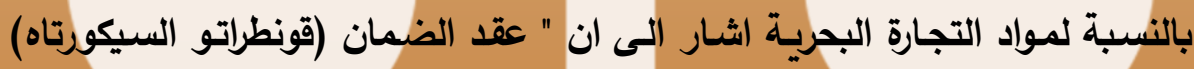

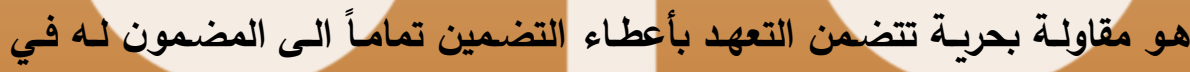

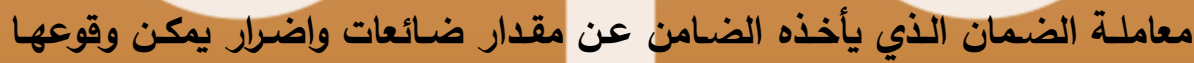
بسبب نائبة بحرية على اشياء يحترز عليها من ان تصادف خطر سفر بحري (3)".

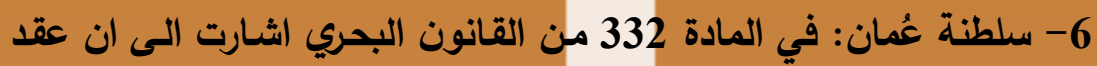

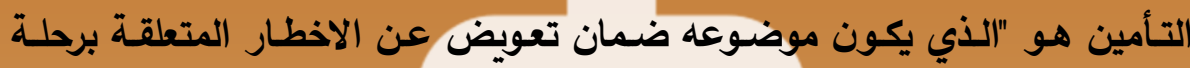
بحربة". (4) بامين هو

7- قطر : في المـادة 233 من القانون البحري اشـارت الى ان عقد التأمين

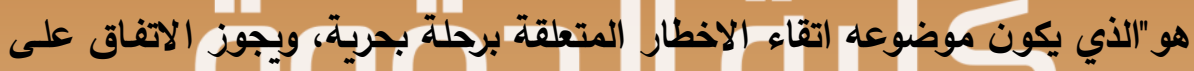

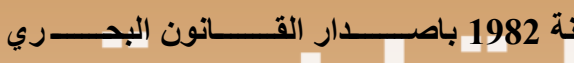

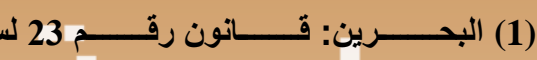
http://www.mtt.gov.bh/Uploads/Documents/PulicationBahrainMaritimeCode1982.pdf 2010 a انتون

http://moj.gov.sd/content/lawsv4/12b/17.htm

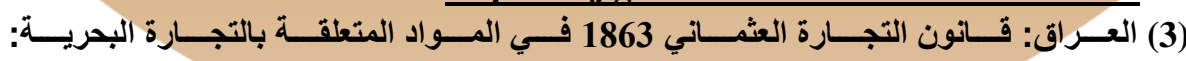
http://www.iraqld.iq/LoadLawBook.aspx?SP=ALL\&SC=280520104356

764\&PageNum $=9$

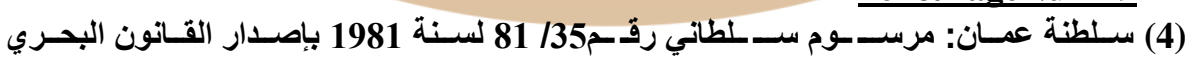
http://www.mola.gov.om/mainlaws.aspx 
مخالفـة هذه الأحكام إلا إذا كانت ذات صفة إلزامية(1)"، وهي ذات الصياغة ايضـا

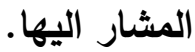

8- الكويت: في المادة رقم 267 من قانون التجارة البحري نصت على ان "

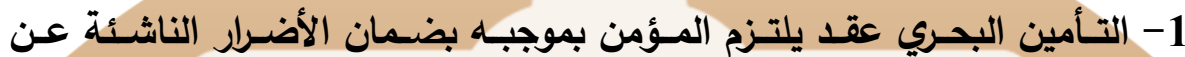

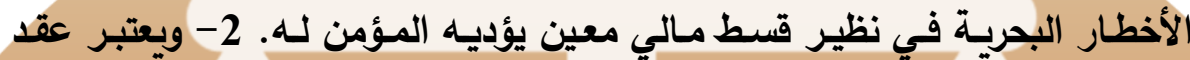

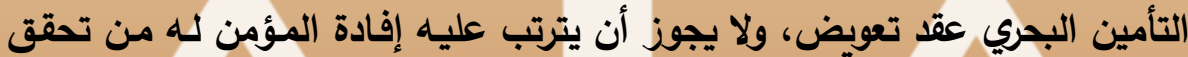

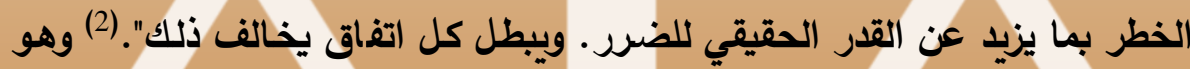

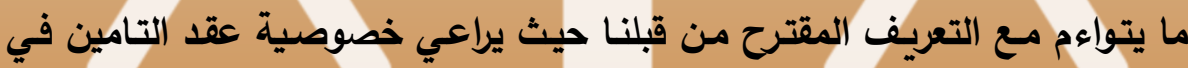
مجال القانون البحري وكذلك خصائصه.

9- لبنـان: في المـادة 61 مـن من قانون التجارة البحريـة اشـارت الـى انـهـ

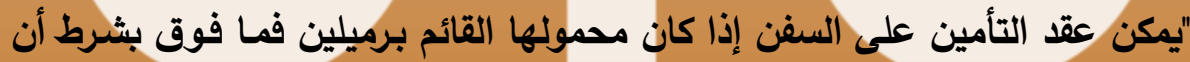

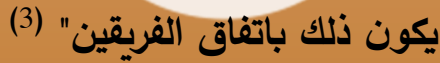

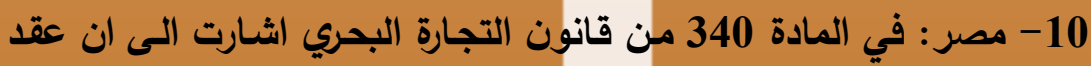

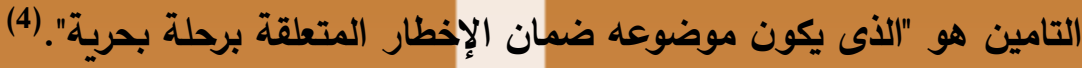

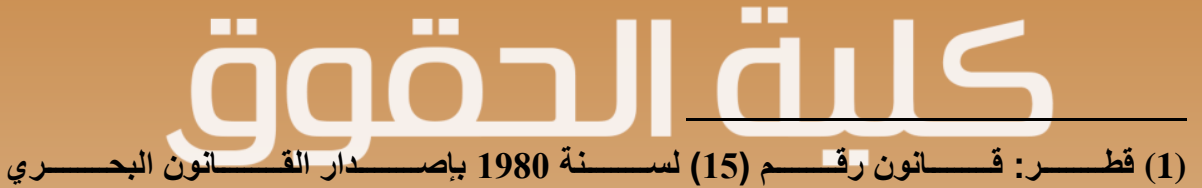
http://www.almeezan.qa/mojportal/LawPage.aspx?id=104\&language=ar (2) الكويت: مرسوم بالقانون رقم 28 لسنـة 1980 باصصدار قَاتون التجـارة البحريـة ( 28 / 1980 ) http://www.gcclegal.org/LawAsPDF.aspx?opt\&country=0\&LawID=1003

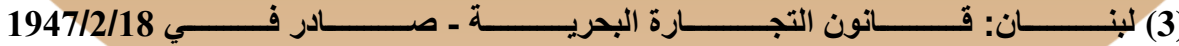
http://www.transportation.gov.lb/topic.aspx?zoneid=24\&head=Sea\&con tentid=59

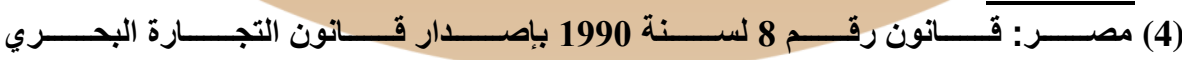
http://www.arablegalportal.org/egyptverdicts/LoadLawBook.aspx?SC $=$ $\underline{090520047847487}$ 
الإلابب الثاني

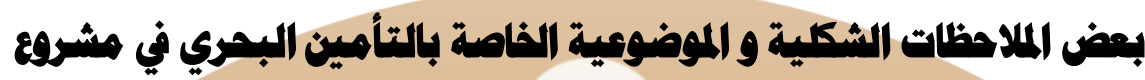

التانمن العربي الاسترشادي البمري 2016

لعل من المسلم به فقها وقانونـا وقضاء بأن تناول موضوع التأمين البحري

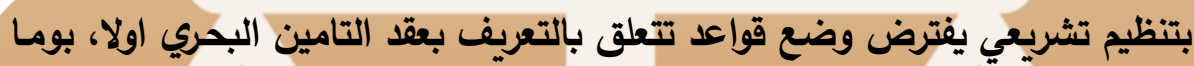

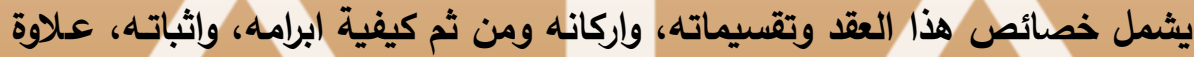

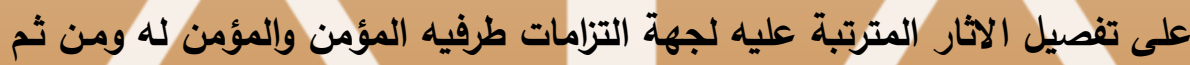

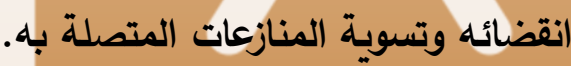

في هذا الاطار ومـن استقراء النصوص التي وضعت في مشروع القانون

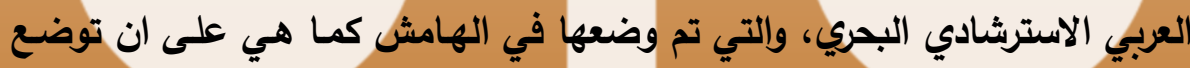

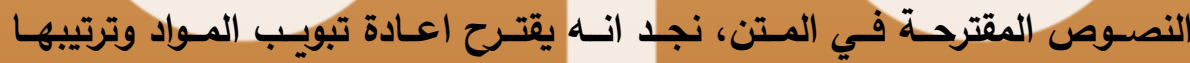
وصياغتها على النحو التالي:

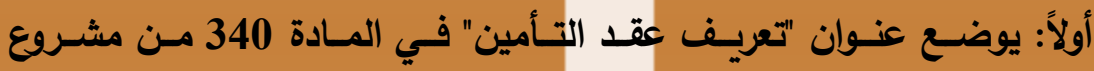
القانون العربي. مادة (340):تسري أحكام هذا (الباب على عقد التأمين الذي يكون موضوعه ضمان الأخطار المتعلقة برحلة بحربة.

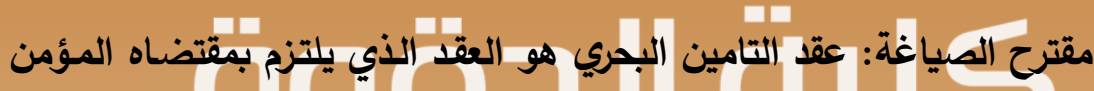

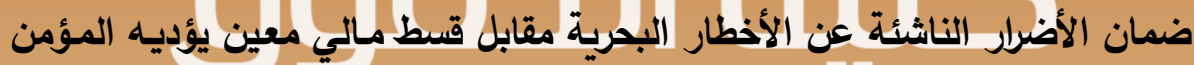

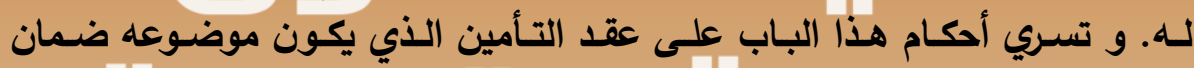

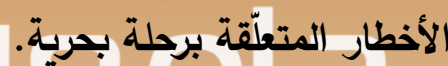
ثانيا: يوضع عنوان "اثبات عقد التأمين" في المادة 341 من مشروع القانون

$$
\text { العربي }
$$

مـادة (341): 1. لا يثبت عقد التأمين وكل مـا يطرأ عليه من تعديلات إلاّ إل

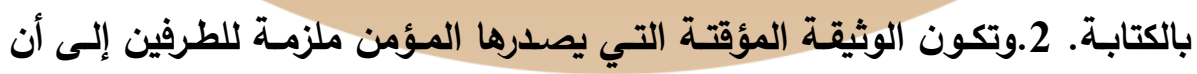
تصدر الوثيقة النهائية. 
العربي الاسترشادي البحري 2016

مقترح الصـياغة: يثبت عقد التـامين اي تعديلات عليـهـ بالكتابـة، وتكـون

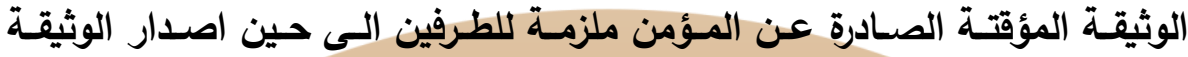
النهائية للتامين البحري.

ثالثاً: يوضع عنوان "وثيقة التأمين"، وتوضع ضمن اطاره المواد 342-343

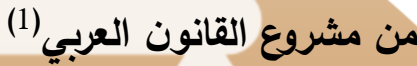

مقترح الصياغة: يعدل فقط بند (و) من فقرة (1) من م 342 بحيث يوضـع مبلغ التامين في بند مستقل عن قسط التأمين.

رابعاُ: يوضع عنوان "نطاق التامين" وتوضع في اطاره المواد 345 و 356-

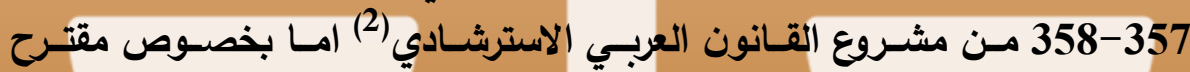
الصياغة فلايوجد.

خامسـاً: يوضـع عنـوان "حـالات ابطـال عقدـ التـأمين" وبضــم المـواد 347-

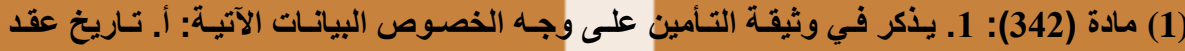

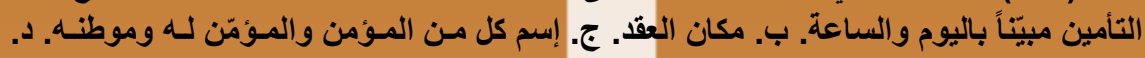

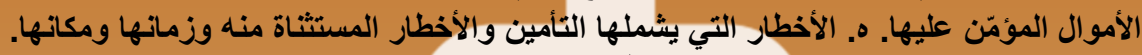

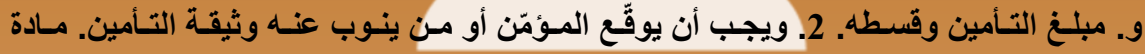

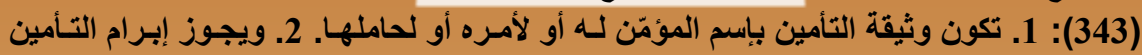

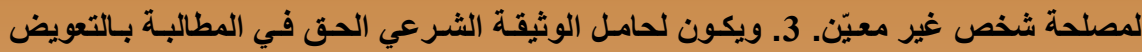

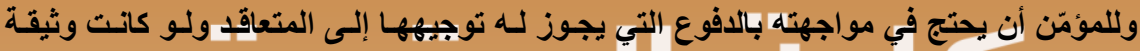

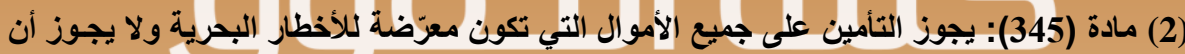

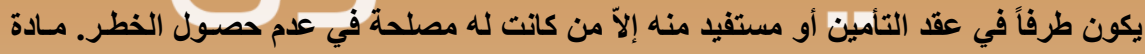

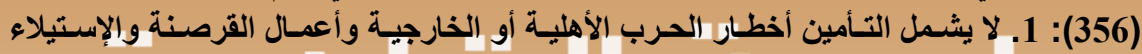

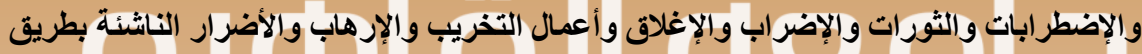

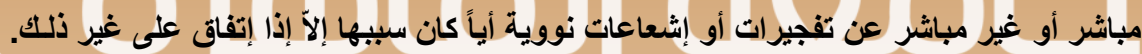

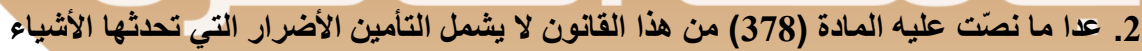

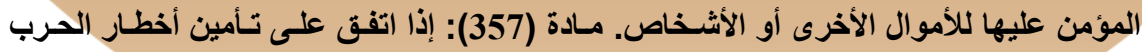

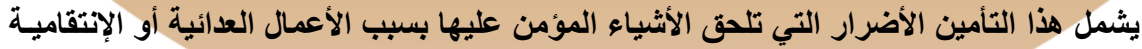

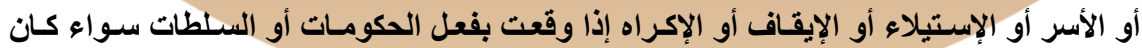

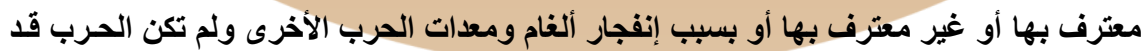

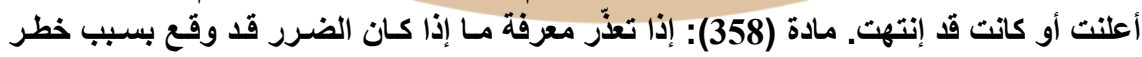
حربي أو خطر بحري، اعتبر ناشئاً عن خطر بحري ما لم لم يثبت خلاف ذلك. 
350-349 من مشروع القانون العربي الاسترشادي.(1)

مقترح الصياغة: في المادة (347): 1. يجوز للمؤمن أن يطلب إبطال عقد

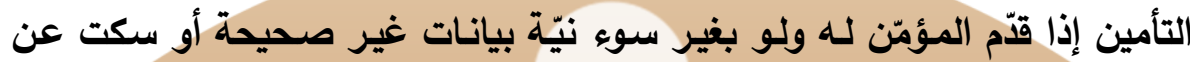

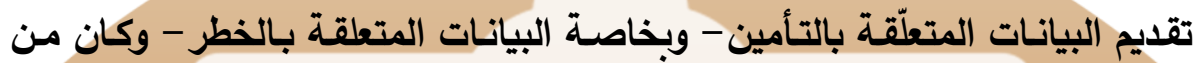

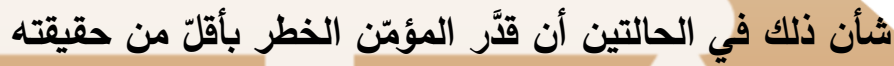

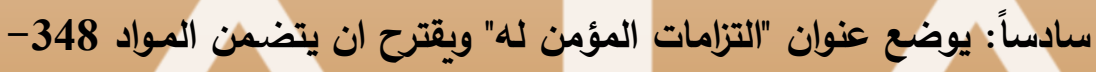

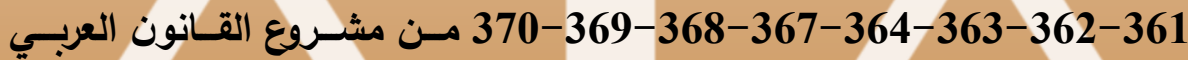

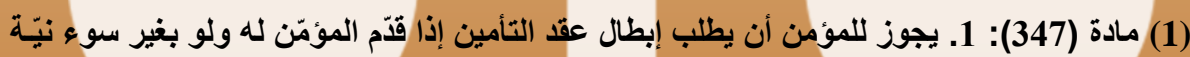

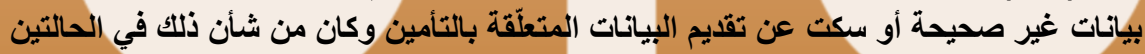

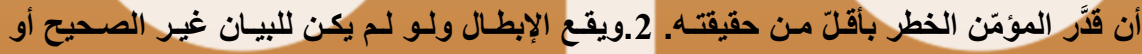

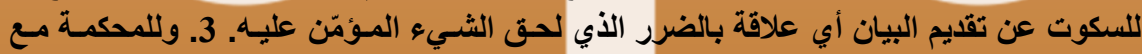

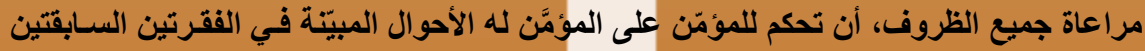

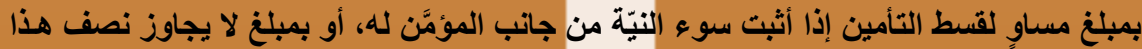

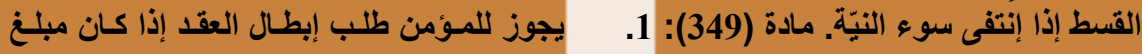

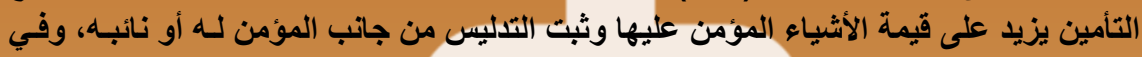

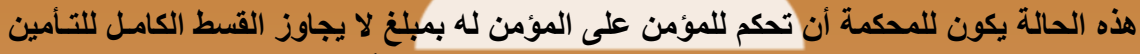

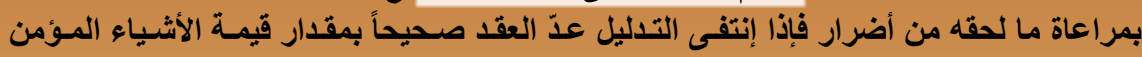

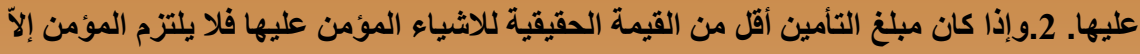

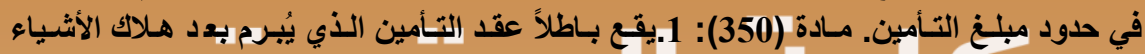

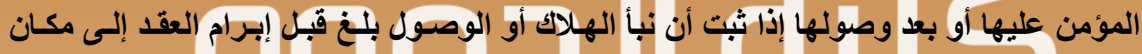

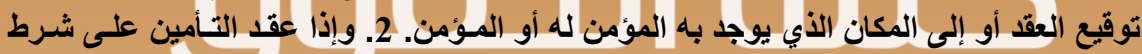

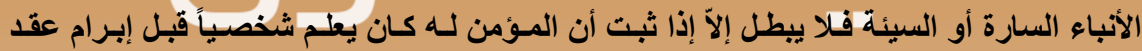

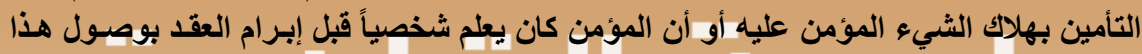

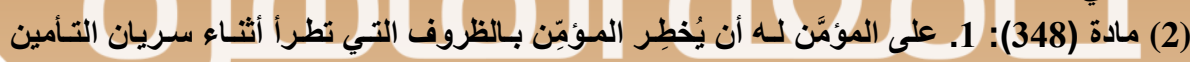

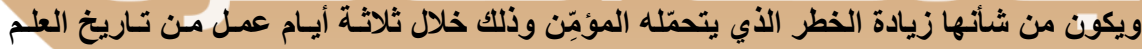

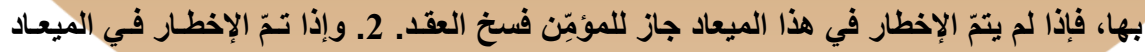

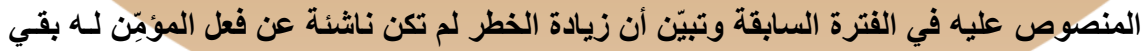

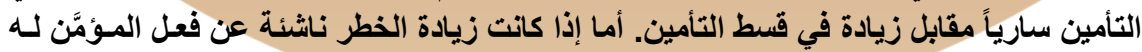

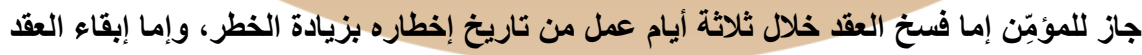

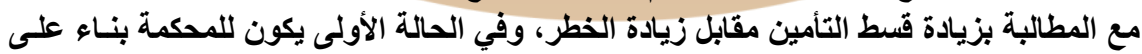

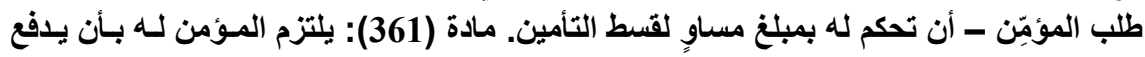


مقترح الصياغة: تضاف في بداية مادة (348): (على المؤمَّن لـه أن يُخطِر

المؤمِّن بدقة وقت ابرام العقد بكل الظروف المعلومـة لـه والتتي يهم المؤمن معرفتها

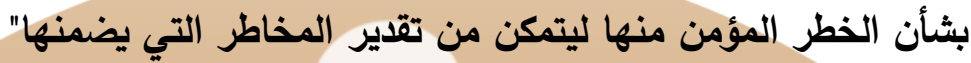
سـابعا: يوضع عنوان " التزامـات المؤمن" ليشـل المواد 353-354-355-

قسط التأمين والمصروفات في المكان والزمان المتفق عليهما، كما يلتزم بأن يبذل الغناية المعقولة

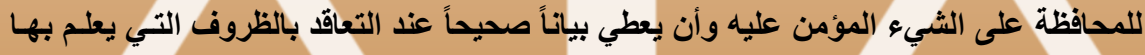

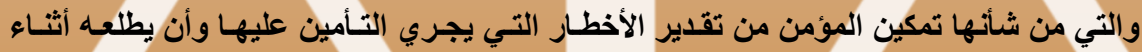

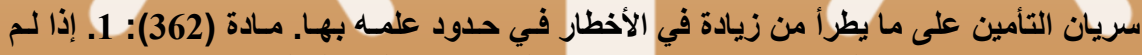

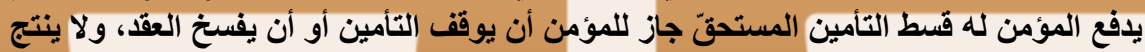

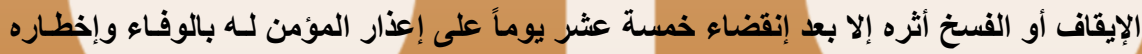

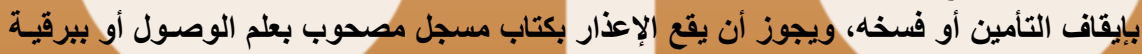

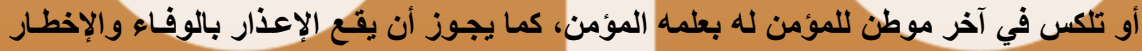

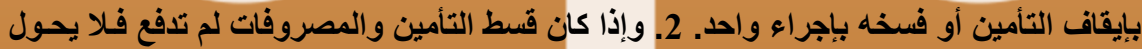

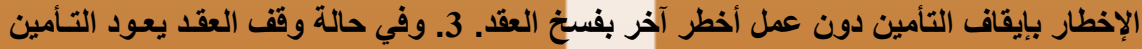

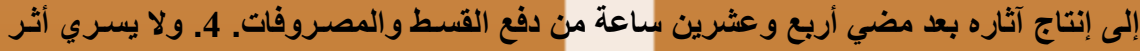

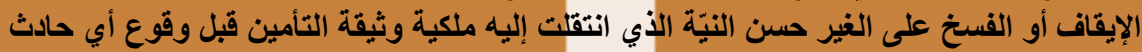

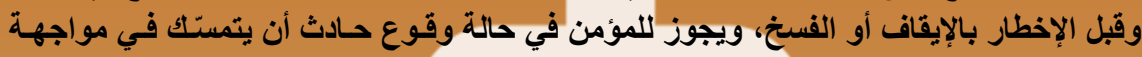

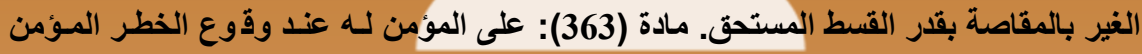

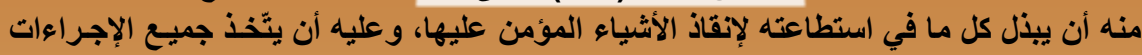

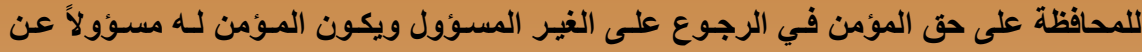

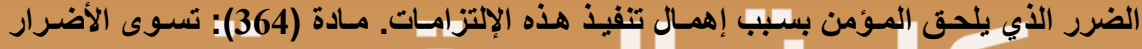

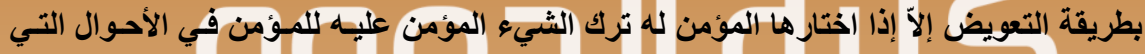

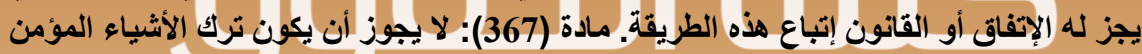

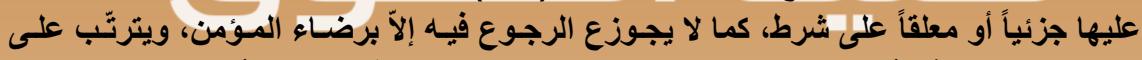

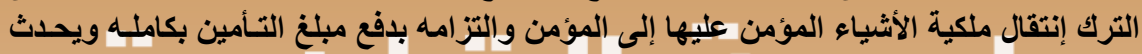

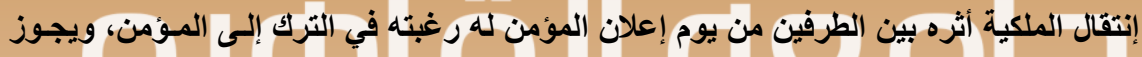

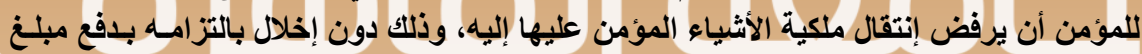

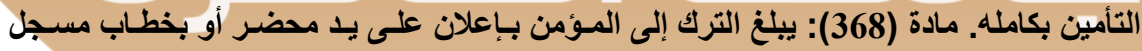

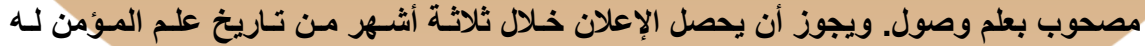

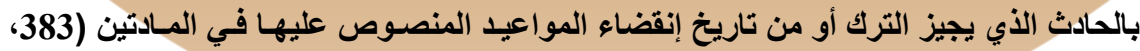

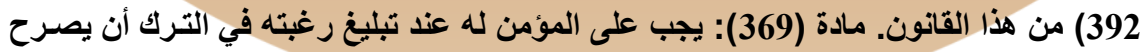

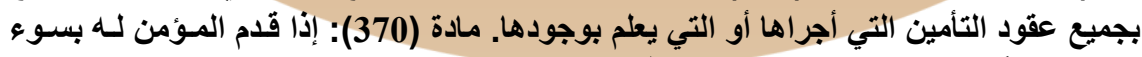

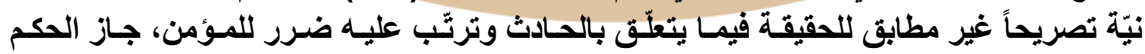
بسقوط حقه في التأمين كله أو بعضه. 


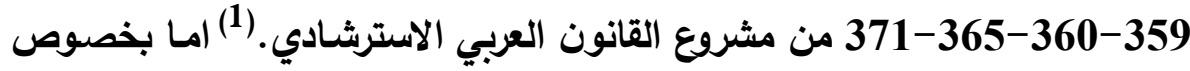

وجود مقترح الصياغة فلا يوجد اي مقترح. منتروعن

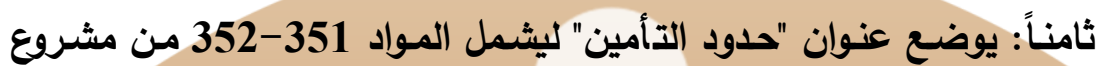

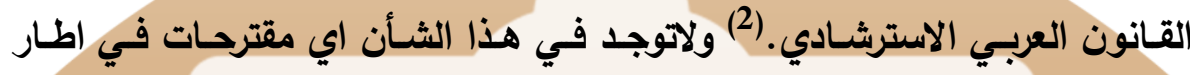

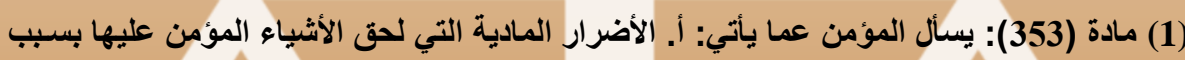

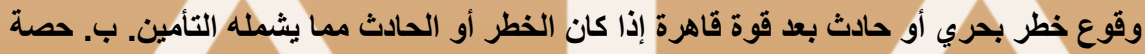

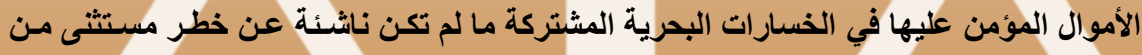

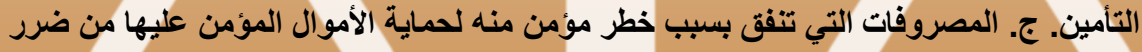

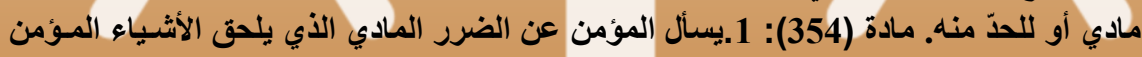

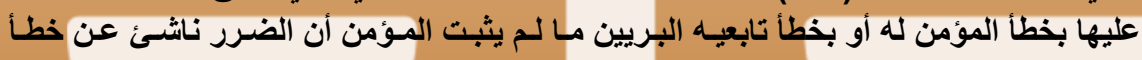

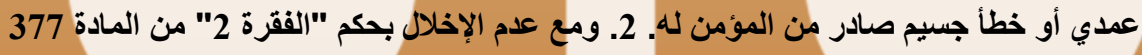

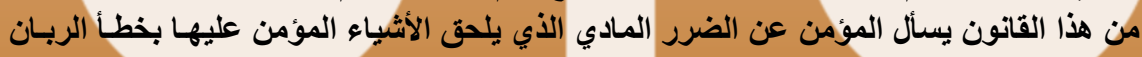

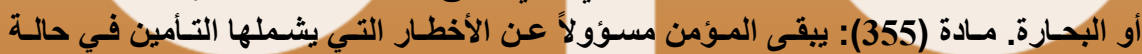

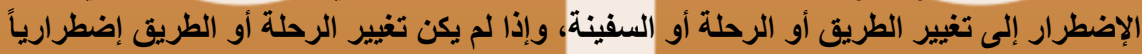

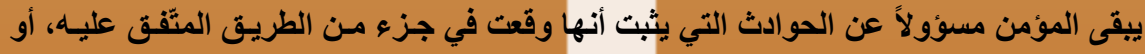

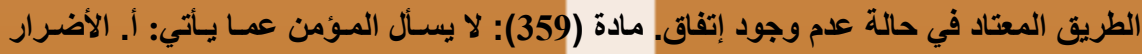

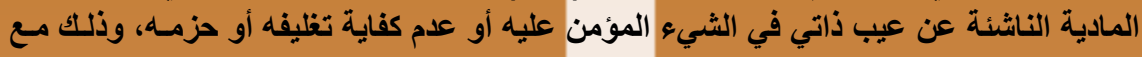

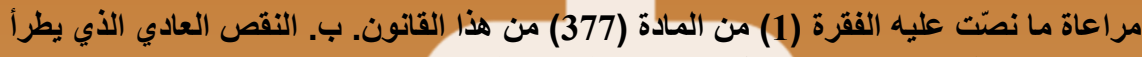

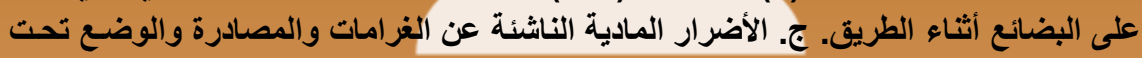

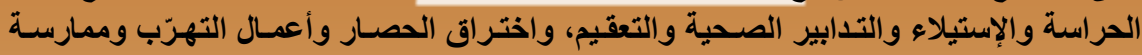

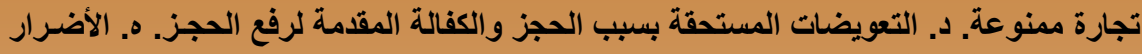

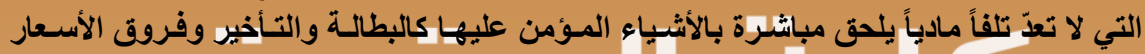

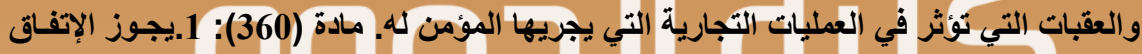

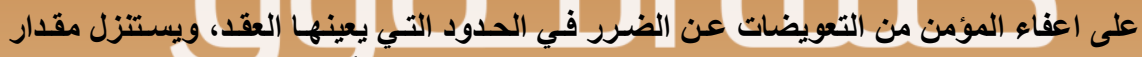

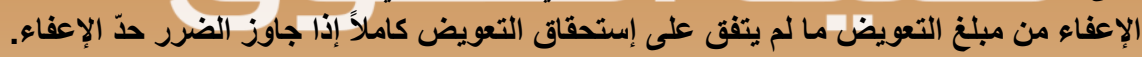

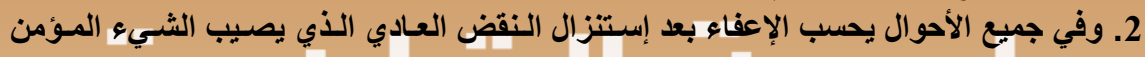

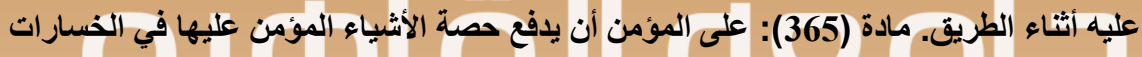

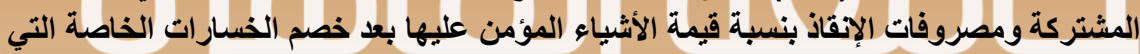

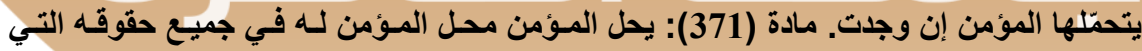

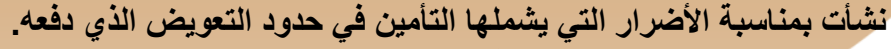

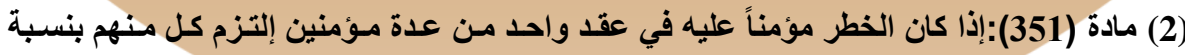

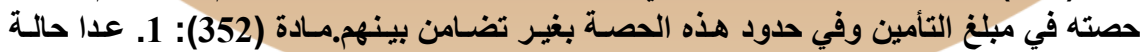

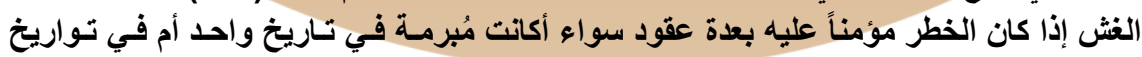

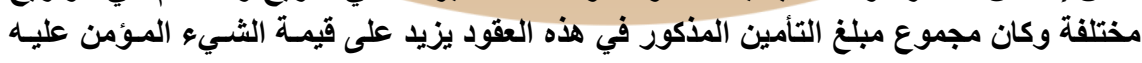

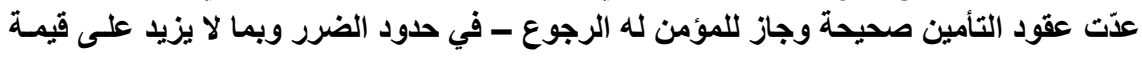




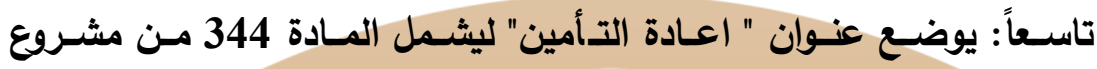

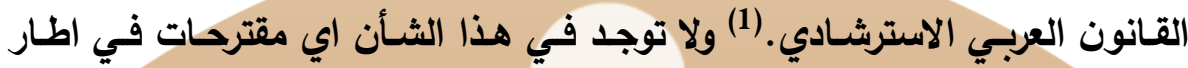

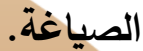

عاشراً: يوضع عنوان "دعوى التأمين" ليثمل المواد 346-372 من مشروع

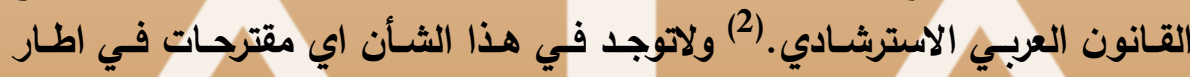

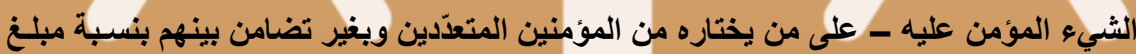

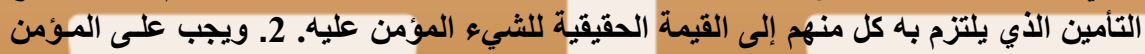

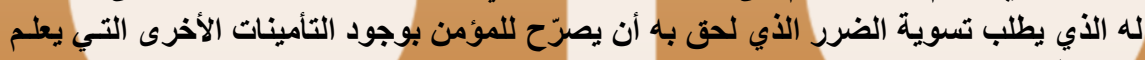

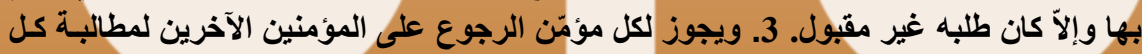

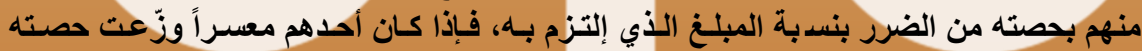

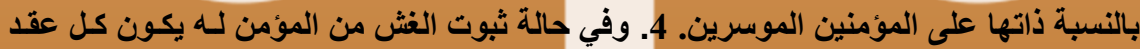

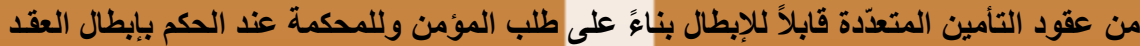

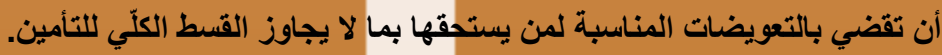

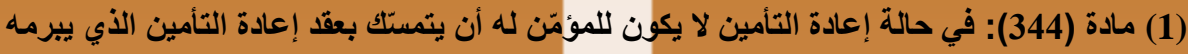

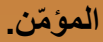

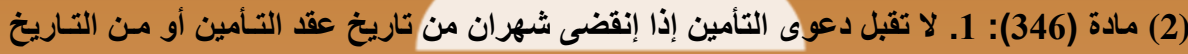

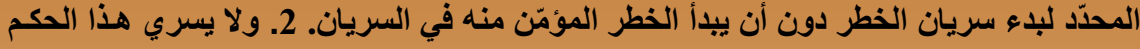

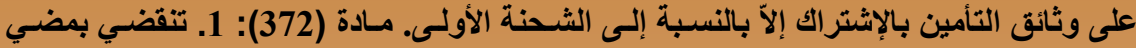

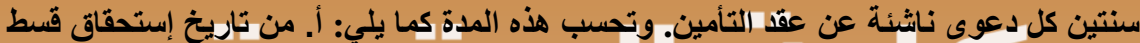

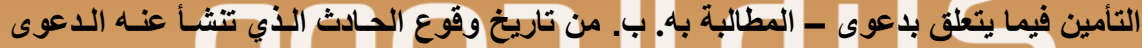

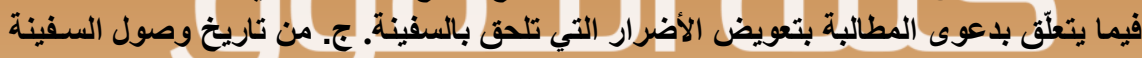

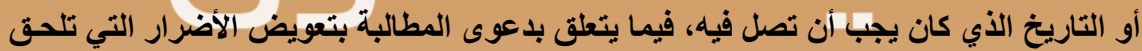

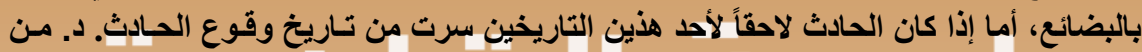

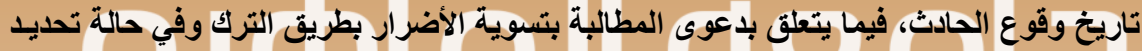

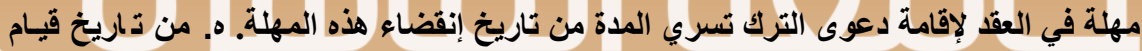

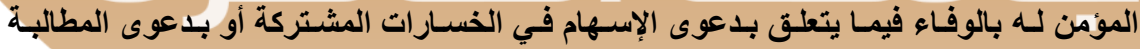

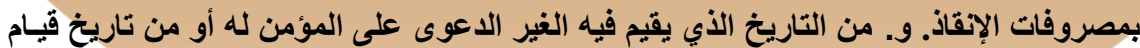

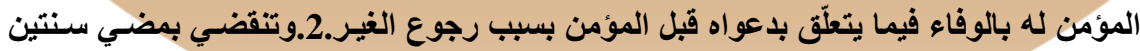

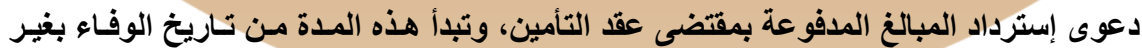

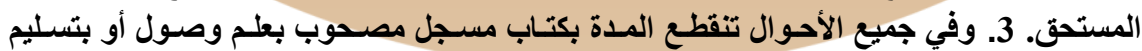
المستثدات المتعلقة بالمطالبة أو بندب خبير لتقدير الأضرار، وذلكك بالإضافة إلى الأسباب المقررة 
الصياغة.

ولعل ايراد ملاحظات شكلية وموضوعية بشأن عقد التامين البحري وتعريفه

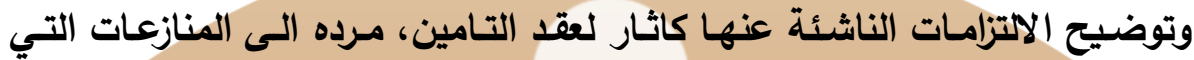

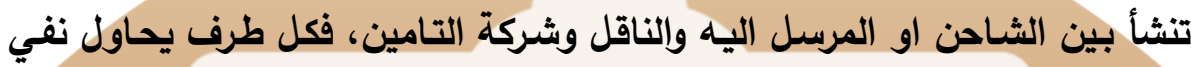

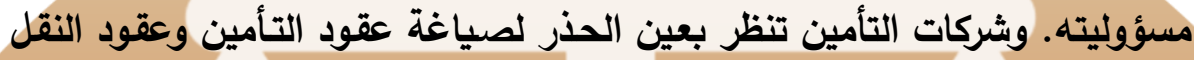

وعملياً فإن نظرة على حكم قضائي مرتبط بهذا الامر يعد من الاهمية بمكان في مجال تعديد المسؤولية في كل من عقدي النقل البحري والتأمين البحري. ففي حكم صادر عن القضاء التونسي، كان الناقل قد ادرج تحفظا في سند

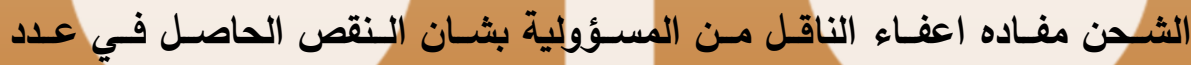

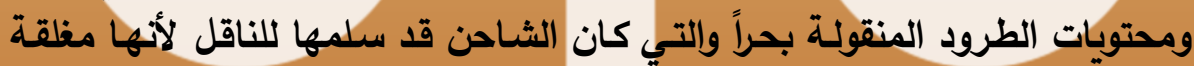

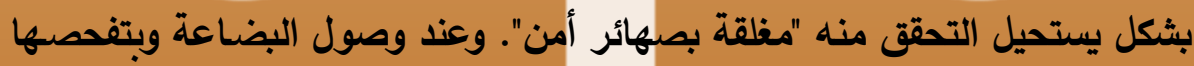

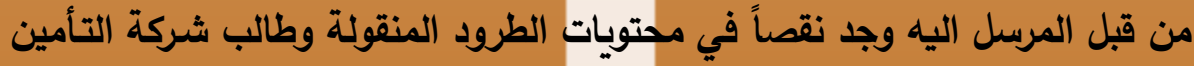

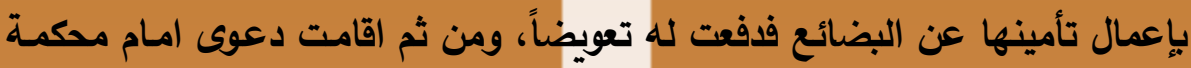
تونس الجزئية لآبات مسؤولية الناقل والزامسه بدفع قيمة البضائع التي نقصت.

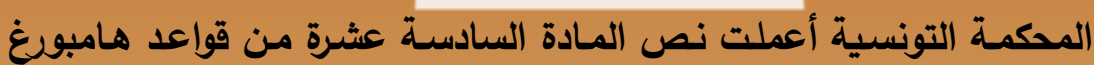

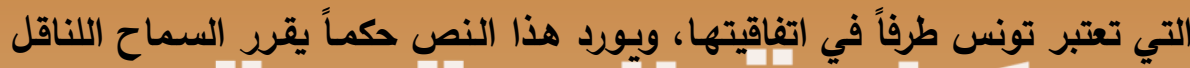

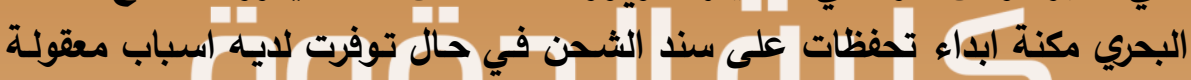

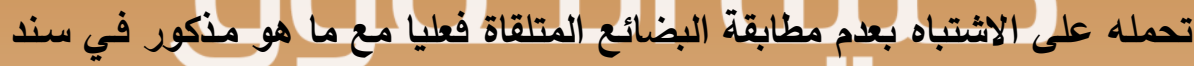

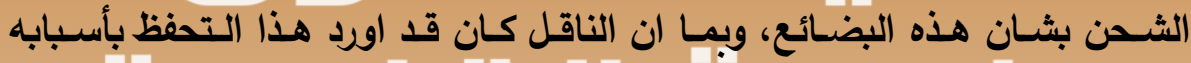

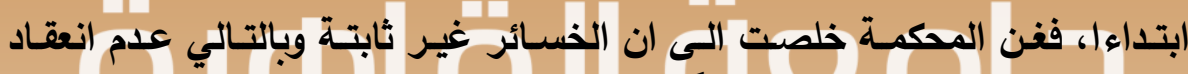

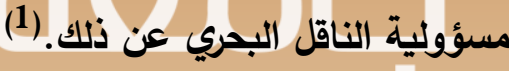

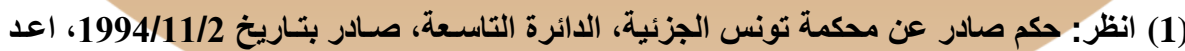

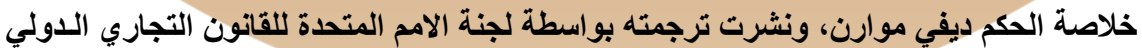

https://documents-ddsعلى الموقع الاكتروني

ny.un.org/doc/UNDOC/GEN/V96/879/57/IMG/V9687957.pdf?OpenElement 


\section{خاتمة ونتائج الدراسة}

عرضنا في دراستنا هذه لبعض مواد المشروع العربي الاسترشـادي البحري،

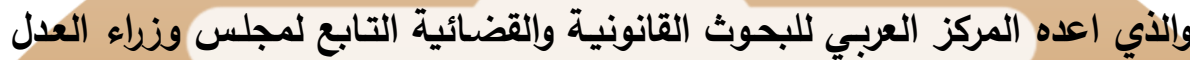
العرب بجامعة الدول العربية.

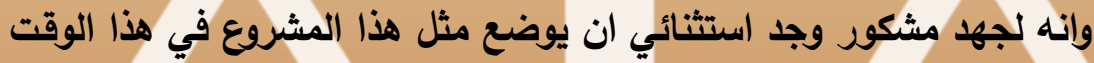

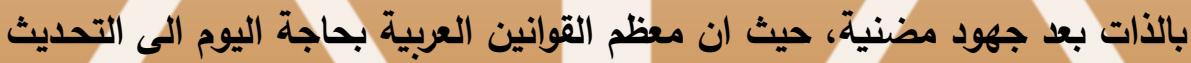

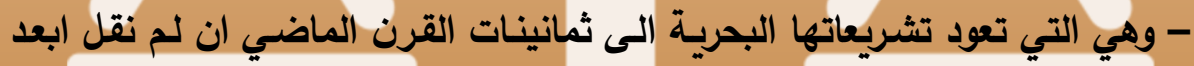

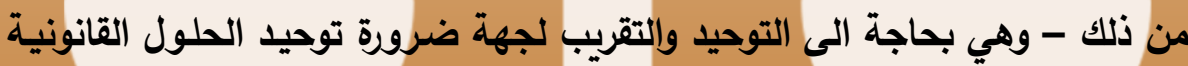
والتوجهات الدولية التي تدفع في هذا الشأن وإلتي تدل عليها قواعد روتي فتردام. في هـا الاطـار فقد ركزنـا بحثنـا واستعراضـنا على المـواد المتعلقـة بالنقـل

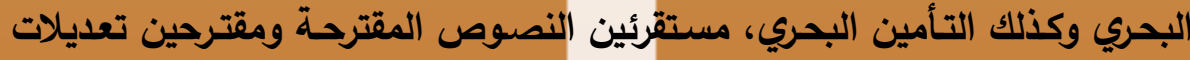

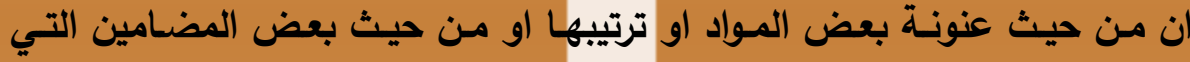

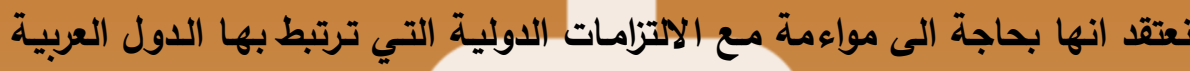

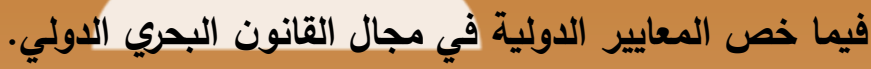
وخلصنا الى مجموعة من المقترحات التي نأمل من الباحثين وخبراء جامعة

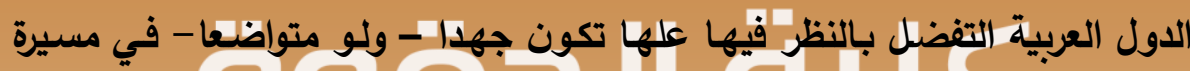
تطوير التشريعات العربية وتوحيدها. ومـن خـلال متضــنات الدراسـة نخلـص الـى ان مشـروع القـانون العربـي

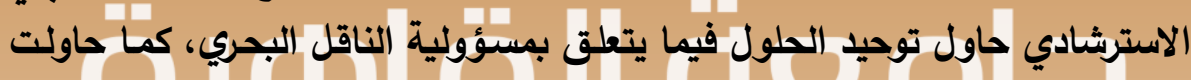
نصوصه فرض نوع من التوازن بين مصالح الناقلين والثاحنين- وقد تمثل ذلك بماتئا

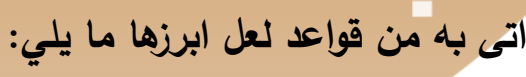

1- حددت محل مسؤولية الناقل البحري ليس عن هـلاك البضـائع او تلفها وحسب بل يشمل ايضا التأخير في تسليم البضائع المنقولة.

2- اسست مسؤولية الناقل البحري عن هـلاك البضـائع المنقولـة او تلفها او 
التأخير في تسليمها على اساس الخطأ المفترض.

3- وضعت تنظيما لمسؤولية الناقل البحري المتعاقد وكنلك الفعلي وايضا في

حالة النقل المتتابع.

4- حددت مدة المسؤولية بالمدة التي تكون فيها البضائع تحت عهدة الناقل

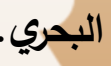

5- وضعت قواعد مفصلة للاختصاص القضائي واللجويء الى التحكيم للفصل

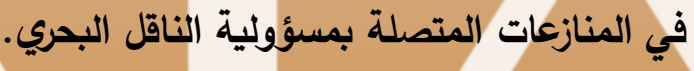

كما خاصنا الى بعض المقترحات تمثلت بالتالي:

1- اقتراح صياغة جديدة لمفهوم عقد النقل البحري استنادا الـى المعايير

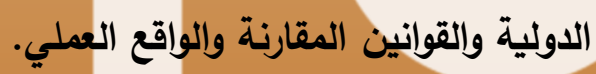

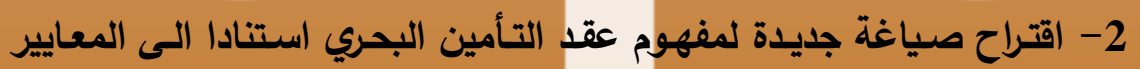

الدولية والقوانين المقارنة والواقع العملي.

3- اقتراح بعض المضـامين والعنـاوين لبعض المـواد الخاصـة بالنقل البحري

والتأمين البحري كما ورد في متن الدراسة.

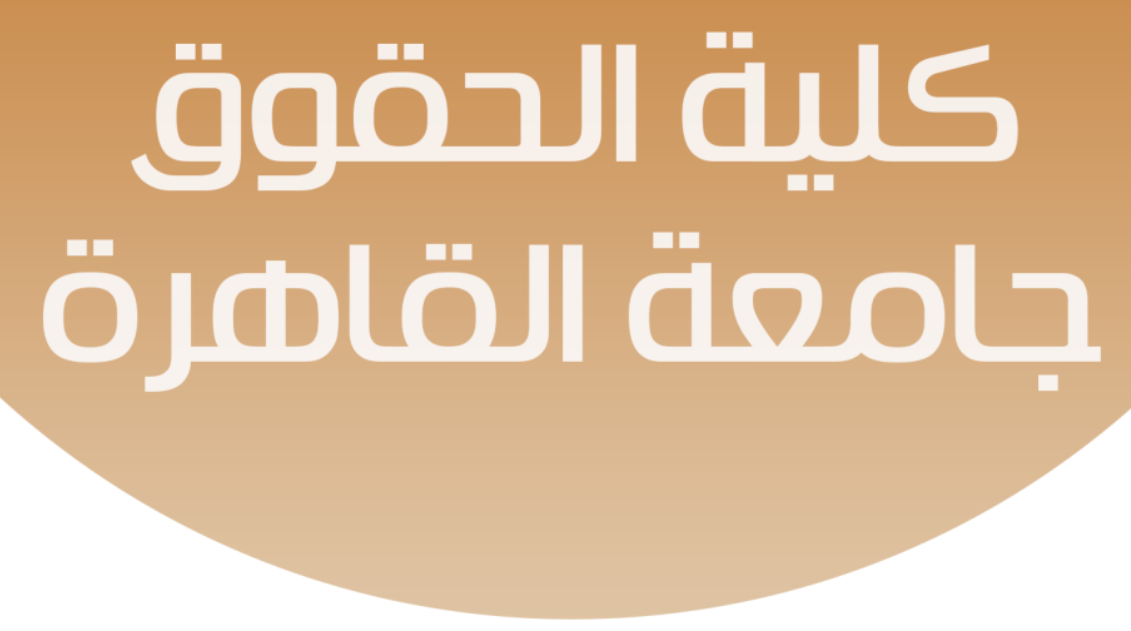




\section{المراجع}

\section{أولا: المراجع العربية}

المراجع العاهة

• البنك الدولي، تقرير عن التمية في العام 2016 ؛(العوائد الرقمية، منشورات

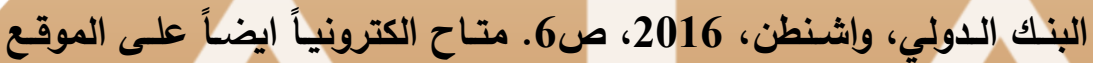
الاكتروني للبنك الدولي.

• د.فايز رضوان، القانون البحري، منشورات كلية شرطة دبي، دبي، 1990.

• د. لطيف جبر كومـاني، مسؤولية الناقل البحري، الـار العلميـة الاوليـة للنشر والتوزيع ودار الثقافة للنشر والتوزيع، عمان -الاردن، 2001.

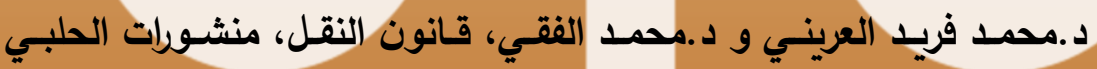
الحقوقية، بيروت، 2011.

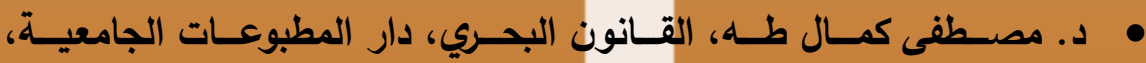

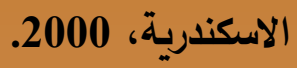
• ـ. هشـام فرعون، القـانون التجـاري البحري، منشـورات جامعة حلب - كلية

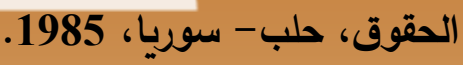

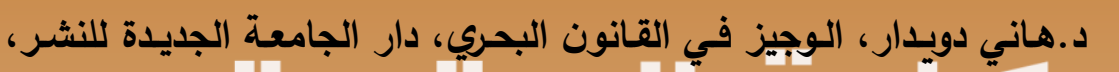

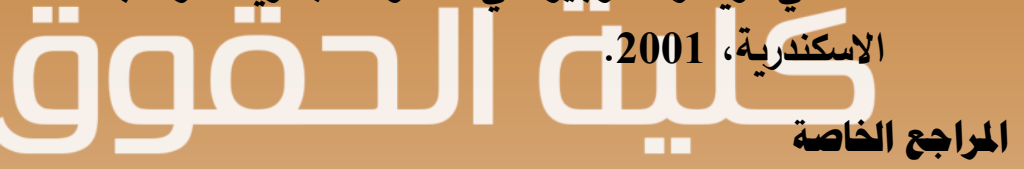
• الامم المتحدة، الاونكتاد، الجوانب القانونية والوثائقية لعقود التامين البحري، منشورات الامم المتحدة، نيويورك، 1982.

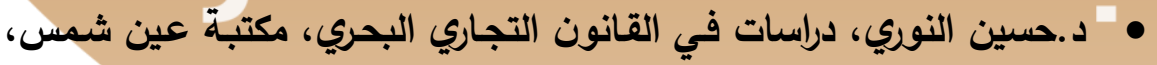

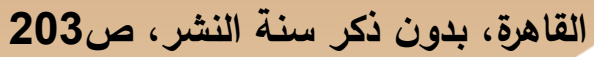

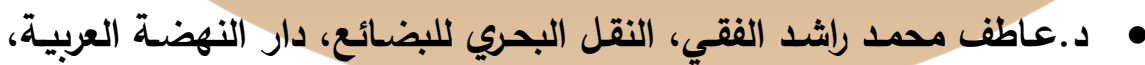
القاهرة، 1997. 


\section{الإقالات والابحاث}

• د.فـاتن حـوى، مسؤولية الناقل البحري وفقـاً لاتفاقية الأمـم المتحدة للنقل

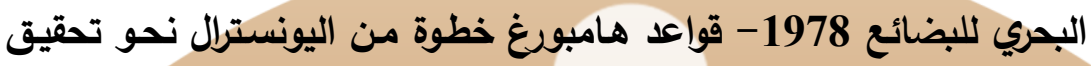

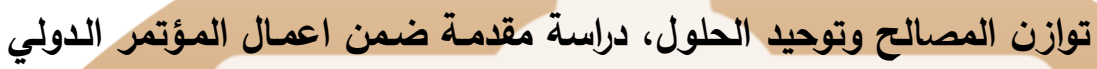

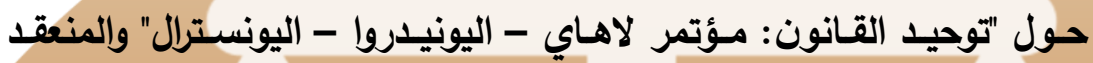

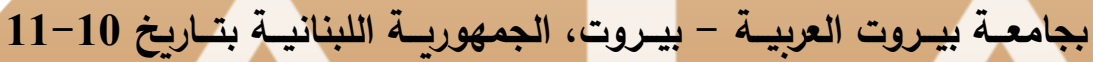

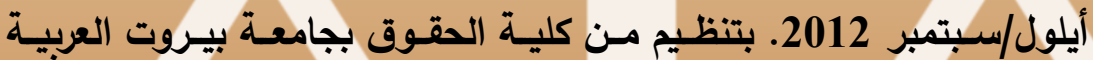

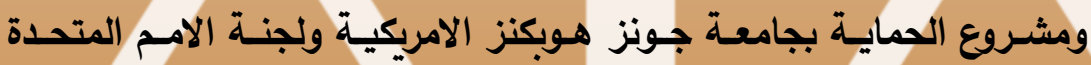
للقانون التجاري الدولي اليونسترال واليونيدروا ومؤتمر لاهاي. د.فايز نعيم رضوان، مسؤولية الناقل البحري الدولي للبضائع وفقا لاتفاقية

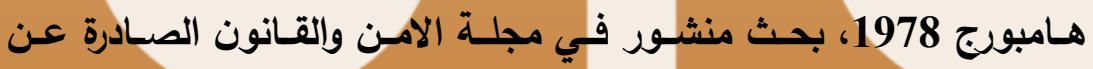

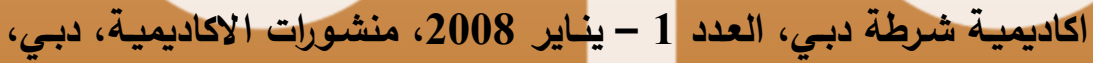

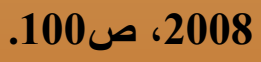

د.فياض القضاة، احكام مسؤولية الناقل البحري "دراسـة مقارنة بين قانون

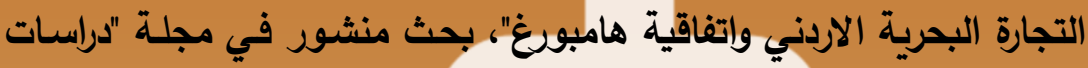

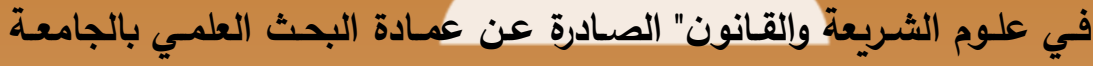

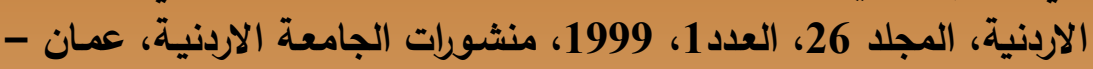

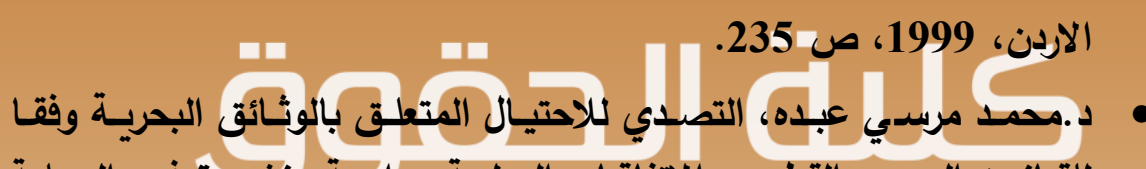

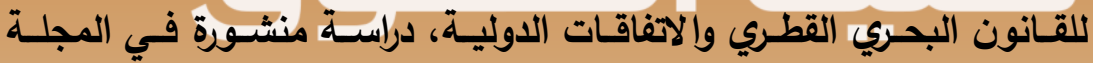

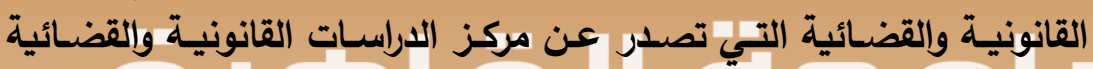

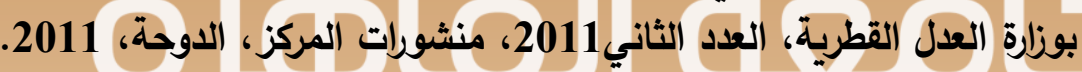

\section{احكام قضائية}

• في تطبيق فكرة هلاك البضاعة بوصولها ناقصة الى مينـاء التفربغ: القضـاء

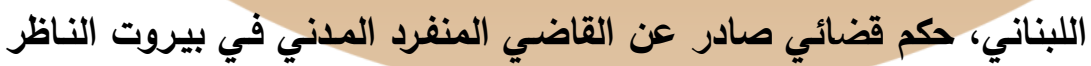
في الدعاوى المالية بموجب قرار رقم 869 الصـادر بتاريخ 27-10-10-2005، 
منشور في مجلة العدل الصادرة عن نقابة المحامين في بيروت، عدد خاص

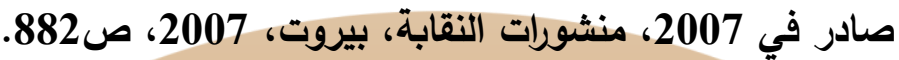
همم صادر عن القضاء اللبناني، بموجب قرار رقم 869 صادر عن القاضي الفي

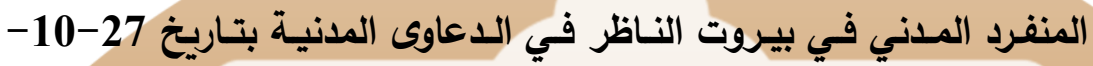

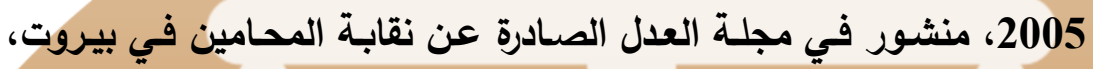

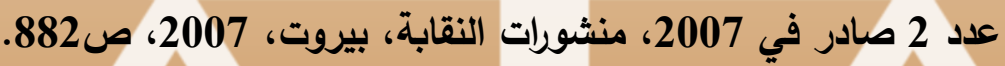

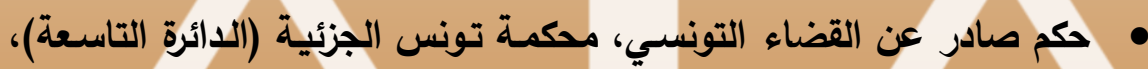

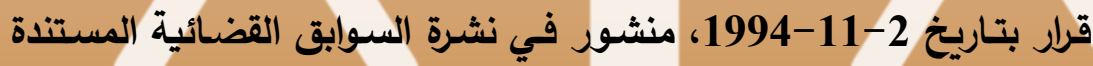

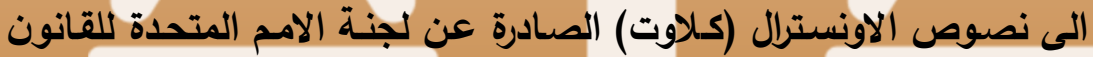

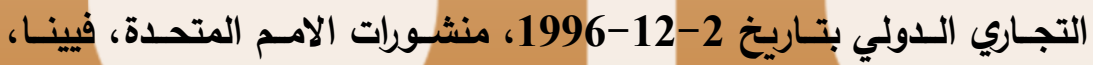

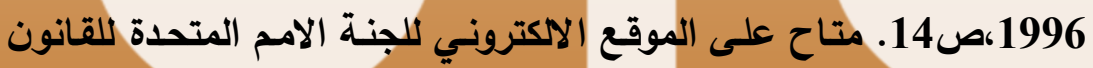

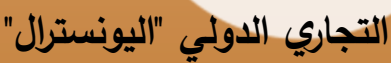

http://www.uncitral.org/clout/searchDocument.do • في تطبيق فكرة التأخير في التسليم: انظر حكم صـادر عن قضاء جمهوريـة

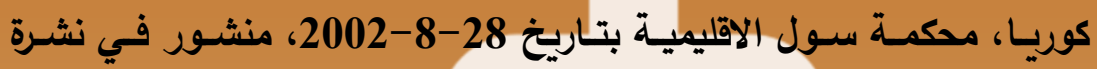

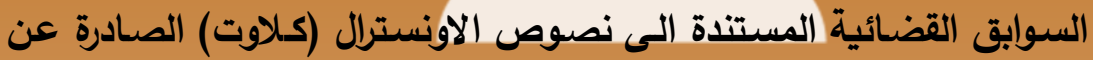

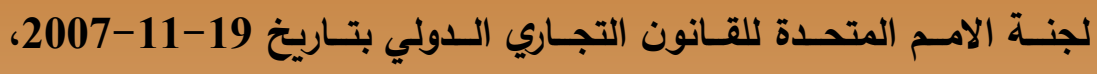

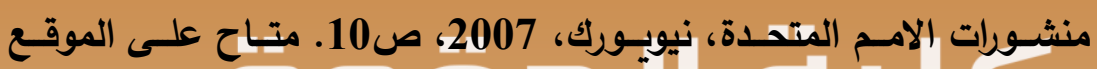

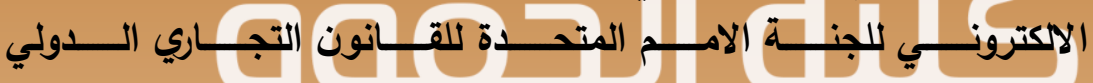
http://www.uncitral.org/clout/searchDocument.do" انظـر : حكم صـادر عن محكمسة تونس الجزئيسة، الـائرة التاسعة، صـادر

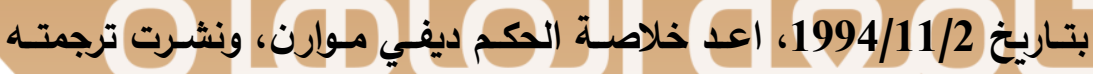
بواسطة لجنة الامم المتدة للقانون التجاري الدولي على الموقع الاكتروني مليكي https://documents-dds-

ny.un.org/doc/UNDOC/GEN/V96/879/57/IMG/V9687957.pdf?OpenElement - اطر قانونية وطنية: 
• الاردن: قانون رقم ( 12 ) لسنة (1972) وتعديلاته الخاص بقانون التجارة

$$
\text { البحرية. }
$$

http://www.lob.gov.jo/AR/Pages/AdvancedSearch.aspx • الامارات: قانون اتحادي رقم 26 لسنة 1981 بشأن القانون التجاري البحري

http://www.elaws.gov.ae/ArLegislations.aspx

$$
\text { • البحرين: قانون رقم } 23 \text { لسنة } 1982 \text { باصدار القانون البحري }
$$

http://www.mtt.gov.bh/Uploads/Documents/Pulication-

$$
\begin{aligned}
& \text { BahrainMaritimeCode1982.pdf } \\
& 2010 \text { السودان: قانون النقل البحرى لسنة }
\end{aligned}
$$

http://moj.gov.sd/content/lawsv4/12b/17.htm

• العرلق: قانون التجارة العثـاني 1863 في المواد المتعلقة بالتجارة البحريـة: http://www.iraqld.iq/LoadLawBook.aspx?SP=ALL\&SC=28 $0520104356764 \&$ PageNum $=9$

• سـلطنة عمـان: مرســوم سـلطاني رقــ35/ 81 لسـنـة 1981 بإصــار القانون البحري

http://www.mola.gov.om/mainlaws.aspx

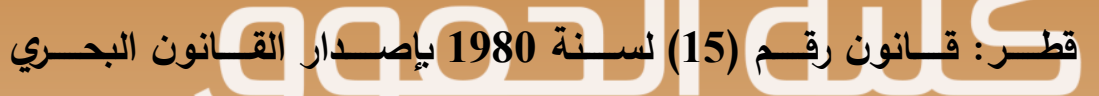
http://www.almeezan.qa/mojportal/LawPage.aspx?id=104\&l

• • الكويست: مرسـوم بالقـانون رقم 28 لسـنة 1980 بإصــار قـانون التجـارة

http://www.gec-

legal.org/LawAsPDF.aspx?opt\&country=0\&LawID=1003 • لبنان: قانون التجارة البحريـة - صادر في 1947/2/18 
http://www.transportation.gov.lb/topic.aspx?zoneid=24\&hea

$\mathrm{d}=$ Sea\&contentid=59

• مصـر : قـانون رقـم 8 لســنة 1990 بإصـــار قـانون التجـارة البحـري

http://www.arablegalportal.org/egyptverdicts/LoadLawBoo

k.aspx?SC $=090520047847487$

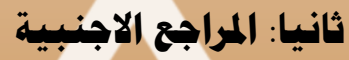

- BERLINGIERI, Francesco, A comparative analysis of the Hague-Visby Rules, the Hamburg Rules and the Rotterdam Rules, paper delivered at the General Assembly of the International Association of Average Adjusters-AMD, Marrakesh, 5-6 November 2009, available online at www.comitemaritime.org/draft/pdf/Comparative_analysis.pdf and:

http://www.uncitral.org/pdf/english/workinggroups/wg_3/Berlin gieri_paper_comparing_RR_Hamb_HVR.pdf

- HONKA, Hannu, United Nations Convention on Contracts for the International Carriage of Goods Wholly or Partly by Sea Scope of application and Freedom of contract, P.2, CMI Colloquium on the Rotterdam Rules, Rotterdam, September 21, 2009, Published and, available online at

http://www.rotterdamrules2009.com/cms/uploads/Def.\% 20tekst $\% 20$ Hannu \%20Honka.pdf

- Paul Page, ROTTERDAM Rules, Rotterdam Rules, Editor's Letter "Rotterdam Rules", Journal of Commerce, 6 July 2009, Publisher; Liam Power, 2009. , available online at 
http://www.uncitral.org/pdf/english/texts/transport/rotterdam_r ules/JOC_editorial_6July09.pdf

- UNITED NATIONS CONFERENCE ON TRADE AND DEVELOPMENT (UNCTAD), Legal and documentary aspects of the marine insurance contract, Report by the UNCTAD secretariat, UN, New York, 1982. Available on line at: http://unctad.org/en/PublicationsLibrary/c4isl27rev1 en.pdf ثالثا: المسادر الالكترونية: قائمسـة بالــدول الاطـراف في قواعـــ هـامبورغ علـى الـرابط الاكترونـي http://www.uncitral.org/uncitral/ar/uncitral_texts/transport _goods/Hamburg_status.html

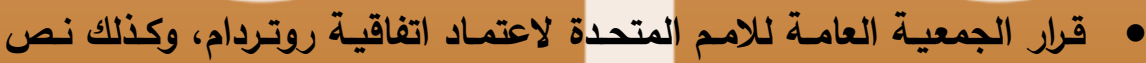

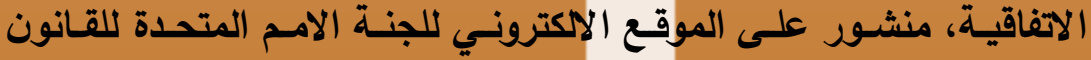

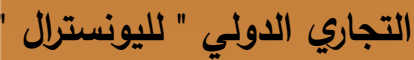

http://www.uncitral.org/pdf/arabic/texts/transport/Rotterda m_Rules/Rotterdam-Rules-A.pdf • قواعد هامبورغ متاحة على الموقع الاكتروني للجنة الامـم المتحدة للقانون http://www.uncitral.org/uncitral/ar/uncitral_texts/transport _goods/Hamburg_rules.html

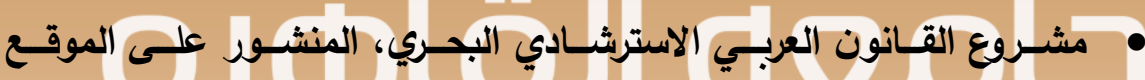

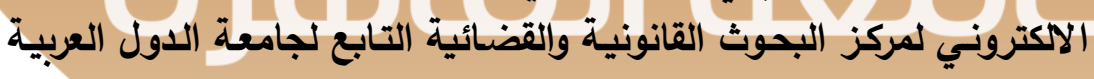
www.carjj.org 